\title{
AVALIAÇÃO DO DESEMPENHO DE SEMEADORAS DE MILHO COM DIFERENTES MECANISMOS DOSADORES
}

\author{
REMI NATALIM DAMBRÓS
}

Engenheiro Agrônomo

ORIENTADOR: Prof. Dr. TOMAZ CAETANO C. RIPOLI

\begin{abstract}
Dissertação apresentada à Escola Superior de Agricultura "Luiz de Queiroz", Universidade de São Paulo, para obtenção do título de Mestre em Agronomia, Área de concentração: Máquinas Agrícolas.
\end{abstract}

P I R A C I C A B A

Estado de São Paulo - Brasil

Janeiro - 1998 
Dados Internacionais de Catalogação na Publicação (CIP)

DIVISĀO DE BIBLIOTECA E DOCUMENTAÇĀO - Campus "Luiz de Queiroz"/USP

Dambrós, Remi Natalim

Avaliaçāo do desempenho de semeadoras de milho com diferentes mecanismos dosadores / Remi Natalim Dambrós. - - Piracicaba, 1998.

86 p. : il.

Dissertaçāo (mestrado) - . Escola Superior de Agricultura Luiz de Queiroz, 1998. Bibliografia.

1. Implemento agricola 2. Milho 3. Semeadora 4. Semeadura (qualidade) I. Título

CDD 633.15 


\title{
AVALIAÇÃO DO DESEMPENHO DE SEMEADORAS DE MILHO COM DIFERENTES MECANISMOS DOSADORES
}

\author{
REMI NATALIM DAMBRÓS
}

Aprovado em: 16.03 .1998

Comissão julgadora:

Prof. Dr. TOMAZ CAETANO CANNAVAM RÍPOLI

ESALQ/USP

Prof. Dr. JOSÉ PAULO MOLIN

ESALQ/USP

Prof. Dr. DURVAL DOURADO NETO

ESALQ/USP

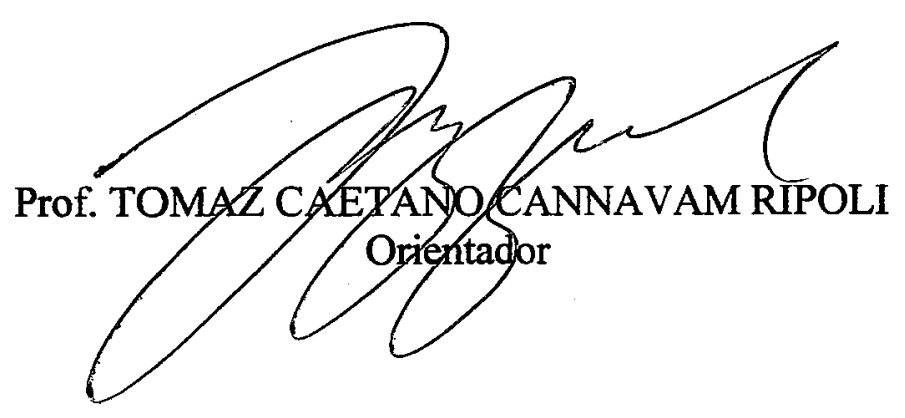


A ciência sem a religião é manca, a religião sem a ciência é cega.

Albert Einstein 
À minha esposa Alice e às minhas filhas Leila e Luciana, pela compreensão nos momentos que estive ausente e pelo incentivo durante a realização deste trabalho.

\section{DEDICO}

Ao meu pai Fortunato João Dambrós e à minha cunhada Helena Hekcler Hermann, (In Memoriam).

À minha mãe Cecilia Tomielo Dambrós e aos meus irmãos. 


\section{AGRADECIMENTOS}

A Deus, pela vida, pelas novas amizades, pela oportunidade de crescer como profissional e como pessoa.

À EPAGRISA, Empresa de Pesquisa Agropecuária e Difusão de Tecnologia de Santa Catarina, pela oportunidade da realização deste curso.

À CAPES, Coordenação e Aperfeiçoamento de Pessoal de Nivel Superior, pela concessão de bolsa de estudos.

Ao Prof. Dr. Tomaz C. Ripoli, pela amizade, orientação e ajuda nas dificuldades encontradas.

Ao Dr. José Paulo Molin, pelas amizade, sugestões e correção final da Dissertação.

Aos professores do departamento de Engenhana Rural, pela dedicação, pelos ensinamentos e sugestões na execução dos trabalhos da Dissertação.

Aos funcionários do Departamento de Engenharia Rural, pela cordialidade, pela presteza nas análises de laboratório e ajuda nos trabalhos de campo. Em especial à dona Lurdes e ao José Geraldo pela bondade e à secretária Sandra pela dedicação.

À colega Eng'. Agr'. Helena M. Pescarin Chamma, pela atenção dispensada ao trabalho, pelo fornecimento do material e informações técnicas nos procedimentos para análise das sementes. Ao estagaário Leonardo pela ajuda nas avaliações das análises.

Aos funcionários da Biblioteca pelas informações fornecidas e qualidade do atendimento, em especial à bibliotecária Kátia pelas correções das referências bibliográficas.

Às empresas Agroeste/SA, Jumil/SA e Pirai/SA, pelo fornecimento do material utilizado nos testes e avaliação das máquinas.

Aos colegas e amigos MS. Carlos Ricardo Fietz e Miltom da Veiga, pela ajuda na arranjo e revisão preliminar da Dissertação.

À colega e amiga Marluce G. Cortez, pelo incentivo na busca do conhecimento e por me fazer acreditar mais em mim. 
Aos colegas do Curso de Máquinas Agrícolas, em Especial ao Alexandre, Aưlio, Cristina Destri, Edmilson, Ezer, José Bonnin, Marli e Rogério, pela amizade, ajuda mútua e contribuição pessoal, elevando o nível do curso e tomando o ambiente de trabalho mais fraterno.

Aos colegas Araújo, Itamar, Ricardo Fietz, Ronaldo Bulhões, Vilson Klein e familiares, pela amizade e incentivo durante a realização do curso.

Aos amigos Cláudio e a Paula do CALQ, pela qualidade do atendimento e pela atenção especial dispensada na impressão final da Dissertação.

Aos amigos Solismar Wenske pela convivência e Juan Delgado pela hospitalidade.

A todos aqueles que não foram citados nominalmente porém deram sua contribuição, fica aqui registrada minha gratidão. 


\section{SUMÁRIO}

Página

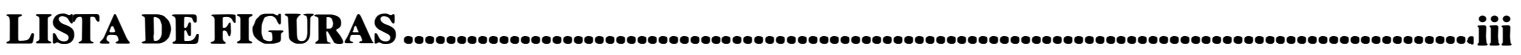

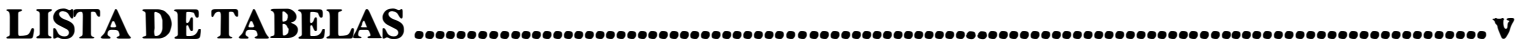

AVALIAÇĀO DO DESEMPENHO DE SEMEADORAS DE MILHO COM

DIFERENTES MECANISMOS DOSADORES ........................................................... vi

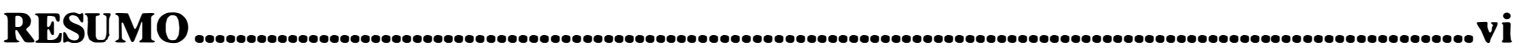

EVALUATION OF CORN PLANTERS WITH DIFFERENT SEED METERS ..viii

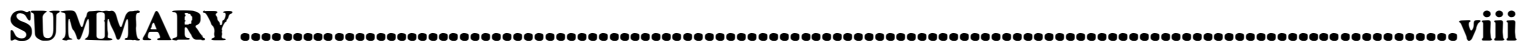

1. INTRODUÇĀ

2. REVISĀO BIBLIOGRÁFICA................................................................................................ 4

2.1. Importância econômica da cultura do milho ..................................................................................4

2.2. Importância do sistema de semeadura para a sustentabilidade agrícola ......................... 7

2.3. Inovações tecnológicas nas semeadoras-adubadoras .................................................................8

2.4. Fatores que afetam a eficiência de semeadura e a população de plantas ....................10

2.5. Influência da eficiência de semeadura e população de plantas na produtividade ... 17

2.6. Parâmetros para medir a eficiência da semeadura ..............................................................22

3. MATERIAL E MÉT TODOS ................................................................................................. 26

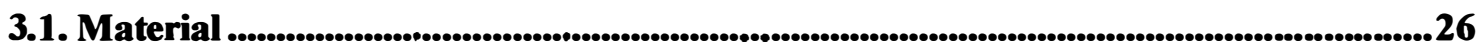

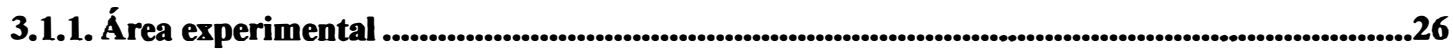

3.1.2. Caracterização das máquinas utilizadas nos experimentos de campo....................................26

3.1.3. Caracterização da bancada de testes .........................................................................................33

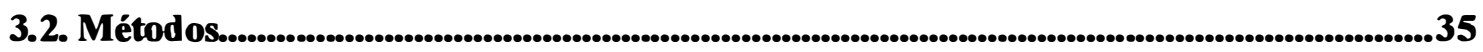

3.2.1. Formação e avaliação da cobertura do solo.......................................................................................35

3.2.2. Caracterização do campo experimental........................................................................................36

3.2.3. Caracterização dos tratamentos e delineamento experimental...............................................37

3.2.4. Semeadura do milho .................................................................................................................................38

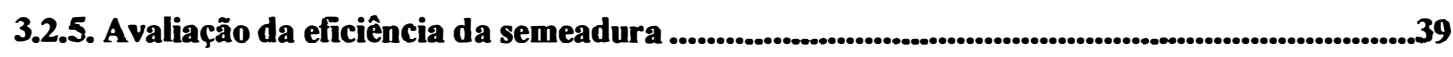


3.2.6. Coleta de sementes para análise de danos fisicos e fisiológicos às sementes..........................43

3.2.7. Análises físicas e fisiológicas das sementes...................................................................................45

3.2.8. Avaliação do enchimento de celas dos discos dosadores ................................................................47

4. RESULTADOS E DISCUSSĀO .................................................................. 48

4.1. Matéria seca e cobertura de palha no solo ..............................................................................48

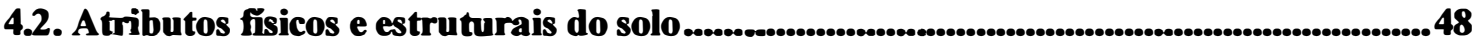

4.3. Características físicas e fisiológicas das sementes.....................................................................50

4.4. Regularidade de distribuị̧ão longitudinal de plantas................................................................52

4.4.1. Coeficiente de variação - CV...........................................................................................................................54

4.4.2. Precisão (coeficiente de variação dos espaços aceitáveis)............................................................56

4.5. Espaçamentos aceitáveis..............................................................................................................................57

4.6. Espaçamentos múltiplos entre plantas ..............................................................................60

4.7. Espaçamentos falhas entre plantas.........................................................................................................61

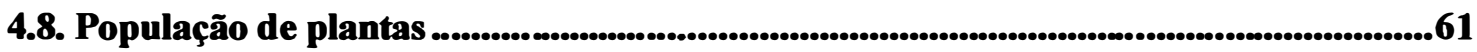

4.9. Danos físicos às sementes....................................................................................................................63

4.10. Porcentagem de germinação ...................................................................................................66

4.11. Porcentagem de vigor ......................................................................................................... 68

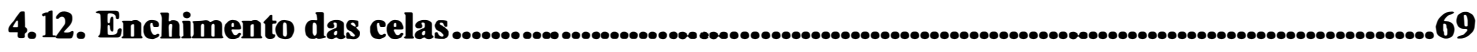

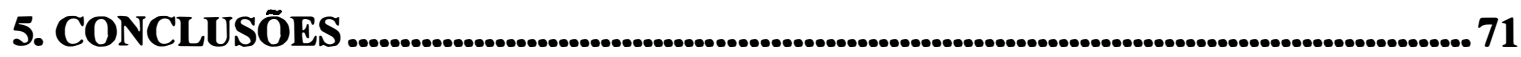

REFERÊNCIAS BIBLIOGRÁFICAS ......................................................................... 73

APÊNDICES........................................................................................................................ 80 


\section{LISTA DE FIGURAS}

Página

Figura 1. Localização das zonas macroagroecológicas produtoras de milho no Brasil.

Fonte: Monteiro, J. de A. (1994). ...............................................................................5

Figura 2. Componentes do sistema dosador de sementes tipo disco perfurado......................28

Figura 3. Vista lateral da semeadora-adubadora de precisão 2040-JUMIL AS, adaptada para semeadura direta.

Figura 4. Sistema dosador pneumático da semeadora adubadora Exata da marca Jumil, utilizado na semeadura nos experimentos (esquerda). Detalhe do seletor posicionado junto aos orificios (direita) (Catálogo Jumil). ........................................32

Figura 5 - Semeadora de precisão tipo pneumática utilizada no experimento.

Figura 6. Bancada de testes para avaliação dos danos às sementes e enchimento das celas (Departamento de Engenharia Rural, ESALQ-USP). .34

Figura 7. Preparo das amostras para avaliação da germinação e vigor das sementes.........46

Figura 8 - Níveis de compactação do solo da área experimental. Média dos 10 tratamentos, obtida com penetrômetro de impacto.

Figura 9. Classificação do milho, cultivar AS-138, pelo diâmetro das peneiras (24 a 19/64 avos de polegada e fundo)

Figura 10. Coeficiente de variação obtido na distribuição longitudinal das plantas nos 10 tratamentos realizados, com as semeadoras de precisão tipo disco perfurado e pneumático.

Figura 11. Percentual de espaços múltiplos, aceitáveis e falhas entre plantas de milho, resultante da semeadura com as máquinas estudadas.

Figura 12. População de plantas obtidas e esperadas por hectare.

Figura 13. Percentagem de danos às sementes que passaram pelos mecanismos dosadores das semeadoras nos tratamentos realizados.

Figura 14. Germinação das sementes que passaram pelos mecanismos dosadores das semeadoras nos tratamentos realizados.

Figura 15. Vigor das sementes que passaram pelos mecanismos dosadores das semea-doras nos tratamentos realizados. 
Figura 16. Número de sementes liberadas por segundo com o aumento da velocidade periférica do disco dosador, $\mathrm{em} \mathrm{m}^{-1} \mathrm{~s}^{-\ldots . \ldots . . . . . . . . . . . . . . . . . . . . . . . . . . . . . . . . . . . . . . . . . . . . . . . . . . . . . . . . . . . . . . . . .69 ~}$ 


\section{LISTA DE TABELAS}

Página

Tabela 1. Produção e produtividade média de milho de 7 grandes produtores mundiais.

(1992-1996).

Tabela 2. Produção e produtividade de milho nos estados pertencentes a região macroagroecológica produtora de milho no Brasil, média dos anos 1992 a 1996.

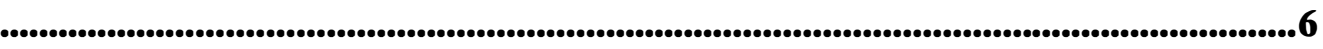

Tabela 3. Características físicas e parâmetros de sementes para projeto de semeadoras...11

Tabela 4. Parâmetros de desempenho de semeadoras-adubadoras sobre bancada de testes no laboratório.

Tabela 5. Produtividade e características morfológicas das espigas de milho irrigado nas cultivares Eperon e Challenger.

Tabela 6. Resultados da avaliação de sete híbridos de milho em quatro densidades de plantio. Campinópolis - MG (1989/1990).

Tabela 7. Parâmetros de avaliação para semeadoras de precisão para testes em laboratório.

Tabela 8. Características técnicas e dimensionais dos mecanismos das máquinas utili-zadas no trabalho.

Tabela 9. Fatores empregados nos tratamentos e seus respectivos níveis, para o estudo da distribuição longitudinal das plantas de milho na fileira.

Tabela 10. Umidade e densidade do solo até a profundidade de $20 \mathrm{~cm}$. 48

Tabela 11. Porcentagem resultante de resíduo de grafite na lubrificação de sementes de milho, nas dosagens de 0,5, 1,0 e 1,5 g de grafite por 500 gramas de milho.......51

Tabela 12. Peso hectolítrico das sementes de milho (média de três repetições).

Tabela 13. Análise da variância dos resultados de campo (média de 4 repetições) .53

Tabela 14. Análise fatorial das médias obtidas no estudo dos fatores: tipo de disco dosador; velocidade de trabalho e; lubrificação das sementes

Tabela 15. Análise de variância dos resultados referentes aos danos provocados às sementes, à germinação e ao vigor.

Tabela 16. Análise fatorial das médias obtidas no estudo dos fatores: Tipo de disco dosador; velocidade e; lubrificação nos danos às sementes. 


\title{
AVALIAÇĀO DO DESEMPENHO DE SEMEADORAS DE MILHO COM DIFERENTES MECANISMOS DOSADORES
}

\author{
Autor: REMI N. DAMBRÓS \\ Orientador: Prof. Titular. TOMAZ CAETANO C. RIPOLI
}

\section{RESUMO}

A uniformidade de espaçamento entre plantas influencia diretamente na produtividade de milho, devido ao melhor aproveitamento de nutrientes, água e luminosidade. Atualmente estão disponíveis, no mercado, semeadoras-adubadoras com sistema dosador tipo disco vertical pneumático, que atendem a esta exigência. No entanto, grande parte dos produtores ainda utilizam semeadoras-adubadoras com dosador tipo disco perfurado horizontal, de menor eficiência na uniformidade de distribuição e com tendência a dano às sementes ao passarem pelos órgãos ativos da máquina. Com o objetivo de avaliar alternativas que permitam melhorar a qualidade de semeadura e a redução dos danos às sementes, realizou-se este estudo em laboratório e no campo. Os fatores avaliados foram: (a) dosador de sementes (disco vertical pneumático, disco perfurado horizontal de ferro e de plástico); (b) velocidades de trabalho das máquinas $\left(1,4 \mathrm{~m} . \mathrm{s}^{-1}\right.$ e $\left.2,1 \mathrm{~m} . \mathrm{s}^{-1}\right) \mathrm{e}$; (c) tratamento de sementes (com e sem lubrificação). O delineamento experimental foi inteiramente aleatorizado com 4 repetições. Realizou-se a semeadura direta do milho sobre matéria seca de Crotalaria juncea e Sorghum halephense, em parcelas de $30 \mathrm{~m} \times 4 \mathrm{~m}$. O desempenho das semeadoras foi avaliado em função da uniformidade de distribuição longitudinal das plantas na fileira. Para tanto mediu-se as variáveis: porcentagem de espaços múltiplos; espaços aceitáveis e falhas; coeficiente de variação; população de plantas e precisão. Foi instalada uma unidade da semeadora sobre a bancada de testes, onde se avaliou o enchimento de celas, variando-se a velocidade periférica dos discos dosadores 
perfurados, de $0,07 \mathrm{~m} \cdot \mathrm{s}^{-1}$ a $0,33 \mathrm{~m} \cdot \mathrm{s}^{-1}$. Foram retiradas amostras de sementes que passaram pelos mecanismos dosadores, nas rotações de 0,36 e 0,53 rps, correspondentes às velocidades de deslocamento de $1,4 \mathrm{e} 2,1 \mathrm{~m} \cdot \mathrm{s}^{-1}$, para análise da germinação, do vigor e dos danos físicos e fisiológicos às sementes. Nas avaliações das semeadoras, observouse maior percentual de espaços aceitáveis entre plantas e menor coeficiente de variação, quando se utilizou a semeadora pneumática com disco dosador vertical, na velocidade de 1,4 m.s $\mathrm{s}^{-1}$. A semeadora de precisão com disco perfurado horizontal de plástico, utilizando sementes lubrificadas, na velocidade de avanço de $1,4 \mathrm{~m} \cdot \mathrm{s}^{-1}$, apresentou resultados próximos aos obtidos com a semeadora pneumática, e superior em relação aos demais tratamentos. A uniformidade de distribuição de plantas decresceu com 0 aumento da velocidade. A lubrificação das sementes proporcionou efeito favorável nos espaçamentos aceitáveis e reduziu os danos físicos às sementes. 


\title{
EVALUATION OF CORN PLANTERS WITH DIFFERENT SEED METERS
}

\author{
Author: REMI NATALIM DAMBRÓS \\ Adviser: Prof. Dr. TOMAZ CAETANO C. RIPOLI
}

\section{SUMMARY}

The corn is a crop that requires an uniformity of plant spacings in order to have better nutrient, water and light utilization. In the market, there are available planters with pneumatic seed meters, that satisfy this requeriment. However, most farmers still utilize planters with horizontal perforated seed meter disk, which has a lower efficiency of distribuition and a tendency of damaging seeds. The present work was carried out in field and laboratory conditions with different seed meters aiming to evaluate alternatives that allow to improve sown quality and to reduce seed damage. The following parameters were evaluated: (a) seed meters (pneumatic vertical disk; iron and plastic perforated disk), (b) machine speeds (1.4 m.s $\mathrm{s}^{-1}$ and $2.1 \mathrm{~m} . \mathrm{s}^{-1}$ ) and; (c) seeds (with and without lubrication). The experiment was run in a complete randomized design, with four replicats for each treatment. The area was managed as no-till and covered with Crotalaria juncea and Sorghum halephense residue, in plots of $30 \mathrm{~m} \times 4 \mathrm{~m}$. A row of each planter was tested in the laboratory for filling of cells in function of peripheral speed of the perforated seed meter, at $0,07 \mathrm{~m} \cdot \mathrm{m} \cdot \mathrm{s}^{-1}$ and $0,33 \mathrm{~m}$. $\mathrm{m} . \mathrm{s}^{-1}$. Seeds that passed through seed meters were tested for germination, vigor and damage. The performance of the seed meters was evalueted in function of the longitudinal uniformity of plants distribuition, damage caused to seeds, and cell filling. The following variables were measuared: multiple index, miss index and feed index, coefficient of variation, precision, physical and physiologic damages to the seeds. It 
was observed higher rate of normal feed index and lower coeficient of variation with the pneumatic disk at the speed of $1.4 \mathrm{~m} . \mathrm{m} \cdot \mathrm{s}^{-1}$. The plastic disk, with lubricated seeds, at $1.4 \mathrm{~m} . \mathrm{m} . \mathrm{s}^{-1}$, presented similar results than those obtained with pneumatic system, and superior than the other treatments. The uniformity of plant spacing decreased with the increase of speed. The lubrication of seeds provided a favorable effect in the normal spacings, and reduced the phisical damage to seeds. 


\section{INTRODUÇÃO}

A indústria nacional de semeadoras-adubadoras tem produzido, nos últimos anos, máquinas de melhor qualidade, atendendo às exigências agronômicas das culturas e à crescente adoção do sistema de semeadura direta. As mudanças nas máquinas estão ocorrendo, principalmente, nos sistemas de rompimento do solo, na distribuição e posicionamento das sementes e do adubo no solo, nos controles de profundidade de semeadura e no pressionamento do solo no sulco.

As inovações surgidas nos mecanismos destinados à melhoria da precisão de semeadura abrangem: rotor inclinado com discos perfurados, copo dosador, dedos transportadores e o sistema pneumático com discos alveolados. Esse último vem ganhando mercado, sendo uma das opções mais modernas em relação à distribuição de sementes. Este sistema possui versatilidade para semear, com qualidade, sementes de espécies e tamanhos variados.

Embora existam semeadoras-adubadoras com todas essas opções tecnológicas, grande parte dos produtores brasileiros não tem acesso às mesmas, devido à falta de conhecimento tecnológico e, principalmente, por questões econômicas. A região Oeste de Santa Catarina, onde predominam propriedades pequenas e médias, é um exemplo dessa situação. Mais de $\mathbf{9 4 \%}$ das propriedades possuem área inferior a 50 hectares e grande parte delas realizam a semeadura de milho e feijão, com máquinas manuais tipo "saraquá". Mesmo com o aumento da motomecanização, o uso da tração animal e de máquinas de pequeno porte ainda são predominantes. Estudo realizado pela Cooperativa de São Miguel D'Oeste, SC, em 1994, constatou que dos 3.400 associados, 613 (18\%) eram sócios proprietários de 499 tratores agrícolas (Testa et al., 1996). 
Segundo os autores, as pequenas e médias propriedades correspondem a 60\% da área agrícola do Oeste de Santa Catarina, Noroeste do Rio Grande do Sul e Sudoeste do Paraná, abrangendo uma área $63.831 \mathrm{~km}^{2}$. Nos últimos anos, com o incremento da motomecanização na agricultura brasileira, tem ocorrido, nessas regiões, a substituição de máquinas manuais por semeadoras-adubadoras de precisão. No geral são máquinas montadas, de 2 a 5 linhas, que realizam trabalho em áreas preparadas no sistema convencional e semeadura direta.

Os discos metálicos perfurados, que compõem o sistema de distribuição de sementes nessas máquinas, estão sendo substituídos por discos de plástico. Porém ambos apresentam limitações e problemas no enchimento das celas e provocam danos às sementes, afetando a qualidade de semeadura. Em operação, as sementes ficam sujeitas a impactos durante a dosagem, sofrendo danos de intensidade e localização variados.

Além da baixa população, outro entrave à obtenção de maiores produtividades é a irregularidade da distribuição de plantas na linha, com o acúmulo de plantas em alguns trechos e falhas em outros. Esta má distribuição afeta a produtividade da cultura devido a maior competição por nutrientes, água e luz, maior incidência de plantas acamadas e quebradas, com reflexos sobre os fatores de produção. Entre os fatores que podem influenciar diretamente na distribuição de sementes e, consequentemente, das plantas nas linhas de semeadura, os principais são a velocidade de trabalho da máquina e os danos mecânicos nas sementes. Os fabricantes recomendam o uso dessas máquinas na velocidade de 1,11 a $1,66 \mathrm{~m} . \mathrm{s}^{-1}$. Um grande número de produtores, quando a regularidade do terreno permite, utilizam essas semeadoras em velocidades superiores às recomendadas pelos fabricantes, afetando sensivelmente a eficiência de semeadura.

Considerando que grande parcela de produtores brasileiros utilizam semeadoras-adubadoras do tipo disco perfurado horizontal, este trabalho foi conduzido buscando testar alternativas capazes de melhorar a eficiência de semeadura, sem reduzir a capacidade operacional da máquina e obter a população de plantas desejada. A 
hipótese fundamental deste estudo é de que a semeadora de precisão, com dosador tipo disco perfurado de plástico, utilizando sementes lubrificadas e trabalhando na velocidade de avanço de 1,4 m.s $\mathrm{s}^{-1}$, produz menor intensidade de danos mecânicos às sementes $\mathrm{e}$ atende à exigência da cultura na eficiência de distribuição das plantas na fileira. Com base nesta hipótese, o presente trabalho foi desenvolvido com os seguintes objetivos:

1) Avaliar o desempenho de semeadoras de milho, na distribuição longitudinal de plantas, na germinação e nos danos mecânicos às sementes, com diferentes tipos de mecanismos dosadores, variando-se a velocidade de trabalho e a fluidez das sementes; e,

2) Medir o enchimento de celas em diferentes velocidades periféricas dos discos perfurados horizontais. 


\section{REVISÃO BIBLIOGRÁFICA}

\subsection{Importância econômica da cultura do milho}

Segundo a FNP CONSULTORIA \& COMERCIO, na edição da AGRIANUAL, (1997), a rentabilidade bruta média na cultura do milho é baixa, sendo inferior a $20 \%$, e o custo de produção desta cultura é de US $\$ 4,50$ a 5,80 por saca. O preço médio dos grãos nos últimos 5 anos, desconsiderando-se as despesas pós-colheita, foi de US\$ 6,10 por saca, em dólares deflacionados para junho de 1996. Portanto, tratase de uma margem apenas regular, considerando-se os riscos da cultura, o preço e o lucro médio com que se está trabalhando.

O milho é produzido em praticamente todo o território brasileiro. Existe, porém, uma região onde se concentra a grande produção deste cereal, denominada de região macroagroecológica produtora de milho (Monteiro,1994). A macroregião é dividida em 14 regiões menores, em função do relevo, tipo de solo, altitude e clima, sendo denominadas de Zonas, pelo autor. Uma Zona abrange geralmente mais do que um estado como pode-se observar no mapa da Figura 1. 


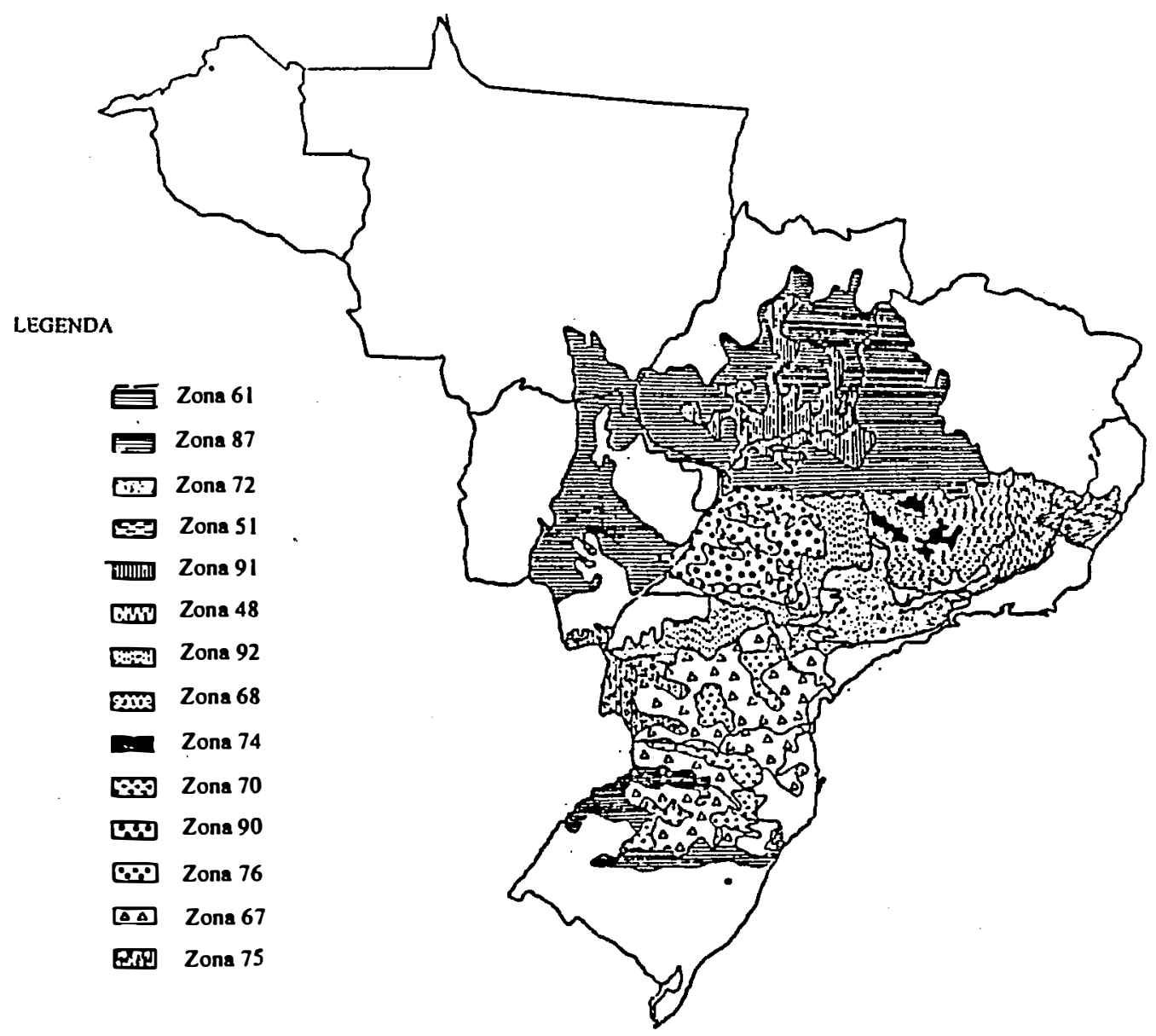

Figura 1. Localização das zonas macroagroecológicas produtoras de milho no Brasil. Fonte: Monteiro, J. de A. (1994).

A produtividade em alguns estados desta região é superior à média nacional, estando próxima a da Argentina, China e superior a do México e da África do Sul, como pode-se observar na Tabela 1.

Tabela 1. Produção e produtividade média de milho de 7 grandes produtores mundiais. (1992-1996).

\begin{tabular}{lcc}
\hline País & Produção (1000t) & Produtividade (kg/ha) \\
\hline Estados Unidos & 207.097 & 7.439 \\
China & 101.626 & 4.738 \\
Brasil & 32.383 & 2.393 \\
México & 17.055 & 2.166 \\
França & 13.532 & 7.726 \\
Argentina & 10.440 & 4.214 \\
África do Sul & 8.347 & 2.384 \\
\hline
\end{tabular}


Tabela 2. Produção e produtividade de milho nos estados pertencentes a região macroagroecológica produtora de milho no Brasil, média dos anos 1992 a 1996.

\begin{tabular}{lcc}
\hline Estados Brasileiros & Producão (1000t) & Produtividade (kg/ha) \\
\hline Paraná & 8.010 & 3.156 \\
Rio Grande do Sul & 4.748 & 2.657 \\
Minas Gerais & 3.980 & 2.666 \\
São Paulo & 3.920 & 2.923 \\
Santa Catarina & 3.409 & 3.258 \\
Goiás & 3.168 & 3.729 \\
Mato Grosso do Sul & 1.180 & 2.644 \\
Mato Grosso & 1.149 & 2.680 \\
Espírito Santo & 280 & 2.162 \\
\hline
\end{tabular}

Fonte: Agrianual, (1997)

As condições edafoclimáticas, aliadas ao potencial genético das sementes de milho disponíveis no mercado e adotando-se tecnologias apropriadas para a cultura, possibilitam atingir produtividades superiores a 12 t.ha $^{-1}$, conforme resultados obtidos em testes de avaliação de culturas conduzidas pela EPAGRI na safra de 1991/92, (Testa et al.,1996). Segundo esses autores, é possivel elevar a produtividade média atual de 3,25 t.ha $^{-1}$ na região produtora de milho de Santa Catarina, para 5 t.ha $^{-1}$, o que resultaria num incremento considerável tanto da produção como da renda dos produtores.

A produção média mundial de milho é de, aproximadamente 500, milhões de toneladas por ano, sendo a comercialização deste cereal superior a 65 milhões de toneladas. O Brasil é um grande consumidor de milho na forma de rações, óleo vegetal e na alimentação da população, sob diferentes formas. Os Excedentes são exportados na forma de óleo vegetal, para a Argentina, Paises Baixos e Singapura. O produto "in natura", é importado da Argentina e dos Estados Unidos, conforme dados de 
AGRIANUAL (1997). Na safra 1995/96 o milho foi a cultura que proporcionou a maior receita agrícola no Brasil, correspondendo a um valor de produção de $\mathrm{R} \$ 4,4$ bilhões, segundo Melo (1996).

\subsection{Importância do sistema de semeadura para a sustentabilidade agrícola}

Segundo Adegas (1997), a sustentabilidade da propriedade rural moderna está baseada nos parâmetros do economicamente viável e ecologicamente correto. A semeadura direta tem demostrado ser um sistema de produção que atende esses requisitos, sendo uma das práticas que melhor atende às atuais necessidades da agropecuária nacional. Com a abertura de mercado e a entrada de produtos de outros paises, principalmente do Mercosul, com preços dos produtos agrícolas mais baixos que os praticados internamente, aumentou-se a necessidade de altemativas técnicas e preservadoras dos recursos naturais.

Calegari (1997), afirma que a exploração indiscriminada das regiões agrícolas do Centro-Sul do país não respeitou a vocação natural das glebas, desencadeando um processo de erosão hídrica e diminuição acentuada dos teores de matéria orgânica e nutrientes do solo. Esse quadro começou a tomar outros rumos com o advento da semeadura direta nos Campos Gerais do Paraná, difundindo-se para diversas regiões do país, e proporcionando melhoria da qualidade dos processos produtivos e aumento da produtividade de grãos.

A mudança do sistema convencional para a semeadura direta ocorreu em função não somente dos aspectos de sustentabilidade ecológica, mas também pela redução dos custos com operações agrícolas, e política de apoio ao sistema de semeadura adotada pelos órgãos governamentais. Esta mudança foi decorrente também da globalização da economia e da produção competitiva, conforme Gassen (1997). Esse autor ressalta, no entanto que, segundo dados da FAO, apenas $10 \%$ dos agricultores da América Latina são considerados capazes de adaptar-se à globalização da economia e 
que de acordo com Testa et al. (1996), apenas 36\% dos agricultores de Santa Catarina são aptos à adaptar-se e, até $50 \%$ poderão ser excluídos do meio rural nos próximos anos.

Gassen (1997), considera que o semeadura direta na pequena propriedade, isoladamente, não proporciona aumento significativo de renda, porém diminui a demanda de mão-de-obra, possibilitando que o produtor diversifique mais a sua produção agropecuária. Segundo o autor, o sistema diminui os custos de produção de cereais, mantém os recursos naturais (solo, água, fauna e flora), em melhores condições e pode proporcionar os mesmos beneficios de conservação e recuperação dos solos alcançados nas grandes propriedades rurais que adotam o sistema a mais tempo.

\subsection{Inovações tecnológicas nas semeadoras-adubadoras}

Segundo Portella et al. (1996), os fabricantes de máquinas têm procurado melhorar o sistema de distribuição de sementes, propondo alternativas em substituição ao dosador tipo disco perfurado de ferro, destacando-se entre estes os discos perfurados de plástico, copo dosador, dedos transportadores e sistema pneumático com discos alveolados. A utilização dos discos perfurados de plástico, em substituição aos discos perfurados de ferro, está ocorrendo, principalmente em função do aspecto econômico, pois o custo do sistema de injeção de plástico na fabricação de discos é menor que o de ferro fundido.

Segundo o mesmo autor, o sistema de rompimento do solo e colocação da semente e de adubo está sujeito às adversidades ocasionadas pelo volume de palha $\mathrm{e}$ obstáculos naturais do próprio terreno. Devido a isso, as máquinas possuem diferentes formatos de discos de corte, tais como o liso, corrugado, ondulado e estriado. Existem, também, sulcadores tipo faca, com espessura inferior a $2 \mathrm{~cm}$, ângulo de ataque de 20 a 25 graus em relação à superficie do solo, com formato reto, inclinado ou parabólico, que realizam o rompimento do solo mesmo em situações de maior resistência à penetração. 
Devido à grande diversidade edafoclimática do país e à introdução de novas espécies de plantas para cobertura do solo existe, atualmente, uma grande diversidade de materiais que são utilizados pelos produtores para a formação da camada de palha e a cobertura do solo pode ser espessa ou não, dependendo da finalidade que se destina (Calegari, 1997). Muitos produtores destinam essa cobertura para alimentação do gado durante uma parte do ciclo vegetativo, causando a compactação superficial do solo devido ao pisoteio (Mello, 1997). As máquinas estão equipadas para realizar o rompimento do solo nessas circunstâncias, podendo realizar o trabalho também em terrenos com irregularidade e obstáculos naturais, dispondo para isso de uma unidade conjunta de disco de corte e facão. Na presença de obstáculos ocorre a elevação do disco, suspendendo o facão e evitando assim o impacto.

As semeadoras podem distribuir $\mathrm{o}$ adubo e as sementes, na profundidade desejada, devido à evolução ocorrida nos discos sulcadores. Esses discos são do tipo duplo defasado (recortado e/ou combinado) e podem realizar, com qualidade, o corte da palha e penetração no solo.

As máquinas, além dos sistemas usuais de controle da profundidade, pressão e curso das molas e ajuste do cabeçalho, possuem rodas limitadoras de profundidade que permitem uma regulagem mais precisa. Estas rodas proporcionam o ajuste para diferentes profundidades de operação e auxiliam a limpeza do mecanismo, não permitindo o revolvimento do solo.

Existe uma variedade de componentes de pressionamento do solo que atendem às necessidades de tamanho e de espécie de semente. Os formatos das rodas compactadoras são os mais variadas possiveis, atendendo às diversidades existentes quanto à umidade do solo, tipo de semente e quantidade de resíduos na superficie. Os componentes utilizados para pressionamento do solo são: roda larga para pressionar o solo sobre a semente no sulco; conjunto de dois pequenos discos côncavos para repor o 
solo ou resíduos revolvidos e; conjunto de rodas estreitas posicionadas em forma de ' $V$ ' para pressionar a parede do sulco sobre a semente (Portella et al., 1996).

Os mesmos autores apontam outras melhorias ocorridas nas máquinas de semeadura direta, quais sejam: redução da altura de queda da semente do dosador até o solo, o que melhora a distribuição longitudinal das sementes no sulco; linhas de semeadura independentes com amplitude de deslocamento, permitindo a realização do trabalho mesmo em terrenos com irregularidades; sistema mecânico e hidráulico de autocompensação do terreno, exercendo pressão de corte da palha e solo de forma homogênea e; rodas pivotadas (articuladas) que acompanham as irregularidades do terreno, permitindo uma distribuição contínua e uniforme de sementes e adubo.

Já está disponível no mercado o monitor eletrônico de semeadoras. É um componente eletrônico que possibilita ao operador o acompanhamento instantâneo das operações de semeadura e monitora a taxa de semeadura (sementes por metro), a área trabalhada por hora (ha/h), a área trabalhada total (ha), a população (sementes/ha), a velocidade de plantio e indica também a variação na queda das sementes.

Essas inovações tecnológicas no sistema de semeadura direta, permitem ao agricultor produzir cereais de verão de forma conservacionista, e também o cultivo de pastagem de inverno na mesma área, diversificando a produção e aumentando a renda econômica por hectare. Esta diversificação é denominada de "Integração LavouraPecuária" segundo Mello (1997).

\subsection{Fatores que afetam a eficiência de semeadura e a população de plantas}

Bernacki et al. (1972), apresentam parâmetros de sementes de milho, que devem ser considerados nos projetos de máquinas, como pode-se observar na Tabela 3. 
Tabela 3. Características físicas e parâmetros de sementes para projeto de semeadoras.

\begin{tabular}{ccccccccc}
\hline $\begin{array}{c}\text { Tipo de } \\
\text { semente }\end{array}$ & $\begin{array}{c}\text { Compri- } \\
\text { mento } \\
(\mathrm{mm})\end{array}$ & $\begin{array}{c}\text { Largura } \\
(\mathbf{m m})\end{array}$ & $\begin{array}{c}\text { Espessura } \\
(\mathbf{m m})\end{array}$ & $\begin{array}{c}\text { Peso 1000 } \\
\text { sementes } \\
(\mathbf{g})\end{array}$ & $\begin{array}{c}\text { Densidade } \\
\text { aparente } \\
\left(\mathbf{k g} / \mathbf{d m}^{3}\right)\end{array}$ & $\begin{array}{c}\text { Angulo de } \\
\text { repouso } \\
(\text { graus })\end{array}$ & $\begin{array}{c}\mathbf{N}^{\circ} \text { de } \\
\text { grãos por } \\
\mathbf{c m}^{3}\end{array}$ & $\begin{array}{c}\text { Densidade } \\
\text { semeadura } \\
(\mathbf{k g} / \mathbf{h a})\end{array}$ \\
\hline Milho & $\mathbf{1 0 , 0 - 2 0 , 0}$ & $\mathbf{5 , 0 - 1 2 , 0}$ & $\mathbf{2 , 0 - 5 , 0}$ & $100-200$ & $\mathbf{0 , 6 5 - 0 , 7 5}$ & 31 & 4,3 & $20-30$ \\
\hline
\end{tabular}

Fonte: Bernacki et al. (1972)

Kepner \& Bainer (1972) recomendam que o diâmetro das celas dosadoras de sementes devem ser $10 \%$ maior que a máxima dimensão da semente e a espessura do disco deve ser igual ao diâmetro médio das mesmas.

Greco et al. (1968), estudando uma semeadora-adubadora operada a velocidade de $1,72 \mathrm{~m} \cdot \mathrm{s}^{-1}$, verificaram uma redução na germinação das sementes em relação àquelas que não passaram pela semeadora, da ordem de 8,5\% para amendoim, $7,5 \%$ para arroz, $2,1 \%$ para milho e $0,9 \%$ para soja.

Razera (1979), avaliou a influência da velocidade de deslocamento da semeadora e do dosador tipo disco perfurado de ferro na porcentagem de quebra de sementes de soja. As sementes após passarem pelos dosadores, foram em seguida, analisadas quanto ao percentual de quebra, pureza fisica, germinação, valor cultural e vigor. $O$ autor observou que com a variação da velocidade de 1,11, 1,66 2,22 e 2,78 $\mathrm{m} . \mathrm{s}^{-1}$, ocorreu o aumento na porcentagem de sementes quebradas, em todas as semeadoras estudadas. A razão desta quebra, segundo o autor, deve-se ao aumento da velocidade do disco dosador e, conseqüentemente, aumento dos choques e abrasão das sementes contra o razador nas bordas dos orifícios dos discos.

Para Ogliari (1990), o aumento da velocidade de avanço da máquina aumenta a velocidade periférica dos discos dosadores e, com isso, a ação dos componentes de ejeção das sementes se tornam mais necessários. Deste modo as sementes não possuem tempo suficiente para sair do alvéolo, ocasionando falhas e sofrendo danificações. 
Butierres (1980), estudou semeadoras com três diferentes mecanismos dosadores de soja: dosador tipo cilindro canelado; disco perfurado com furos oblongos; $\mathrm{e}$; mecanismo dosador tipo disco perfurado com furos redondos. $\mathrm{O}$ autor avaliou, em laboratório, a uniformidade de distribuição e danos às sementes. Os fatores estudados foram: tipo de mecanismo dosador; velocidade da máquina; tamanho das sementes; altura das sementes no reservatório e; posições de inclinação das semeadoras. As conclusões do autor foi de que o que mais influenciou na uniformidade de espaçamentos foram os tipos de dosadores. O tamanho das sementes foi significativo na qualidade de distribuição de sementes. Ao diminuir a altura das sementes no reservatório melhorou a qualidade de semeadura quando trabalhou na velocidade de $0,94 \mathrm{~m} \cdot \mathrm{s}^{-1}$. Houve maior redução na germinação das sementes, para a semeadora de disco perfurado horizontal com furos oblongos.

Um estudo semelhante, procurando avaliar a qualidade de semeadura de grãos, foi realizado por Monteiro (1989), com uma semeadora pneumática. O autor propôs um dosador pneumático que apresentasse soluções para o problema de captura, transporte e deposição das sementes no sulco. Avaliou também o desempenho do dosador através das variáveis: captura de apenas uma semente por cela, uniformidade da distribuição longitudinal e danos mecânicos às sementes. As conclusões do trabalho foram de que a captura de apenas uma semente por cela mostrou ser função do diâmetro do orifício de sucção, da pressão, formato da cela e rotação do elemento dosador. A qualidade de distribuição das sementes no sulco é função do tempo dispendido pelas sementes, desde a saída do mecanismo dosador até o solo, e da velocidade de deslocamento da máquina.

Tourino \& Daniel (1996) estudaram o efeito da velocidade periférica do disco dosador de sementes e altura de queda sobre a uniformidade de espaçamento longitudinal entre sementes de soja. Utilizaram as velocidades tangenciais de 0,190 , $0,252,0,310$ e $0,386 \mathrm{~m} \cdot \mathrm{s}^{-1}$ nas alturas de queda das sementes de 200,300 e $400 \mathrm{~mm}$, em semeadoras com dosador tipo disco inclinado e horizontal. Os autores concluíram que 
a velocidade tangencial dos dosadores de $0,190 \mathrm{~m} . \mathrm{s}^{-1}$, proporcionou maior uniformidade de distribuição de sementes, com $51,2 \%$ de espaçamentos aceitáveis quando utilizado disco dosador tipo horizontal e 46,6\% com disco inclinado. A altura de queda das sementes, para os dois tipos de mecanismos exerceu influência significativa na uniformidade de distribuição de sementes utilizando-se tubos condutores originais.

Kurachi et al. (1993) avaliaram em bancada de testes, sete semeadoras de milho com sistema de dosagem de discos perfurados horizontais, inclinados e pneumáticos. Os autores observaram que, de maneira geral, a qualidade da distribuição de plantas na fileira piorou com o aumento da velocidade e tipo de mecanismo dosador de sementes. A semeadora pneumática obteve as porcentagens mais elevadas de espaçamentos aceitáveis, próximo a $90 \%$, e valores de CV abaixo de $35 \%$, nas velocidades de $1,11,1,66,2,22$ e $2,78 \mathrm{~m} . \mathrm{s}^{-1}$, como pode-se observar na Tabela 4.

Tabela 4. Parâmetros de desempenho de semeadoras-adubadoras sobre bancada de testes no laboratório.

\begin{tabular}{|c|c|c|c|c|c|c|c|c|c|}
\hline \multirow[t]{3}{*}{ SEMEADORAS } & \multirow{2}{*}{\multicolumn{4}{|c|}{$\begin{array}{c}\text { Espaçamentos aceitáveis } \\
(\%) \\
\text { Velocidade }\left(\mathrm{m.s}^{-1}\right)\end{array}$}} & \multirow{2}{*}{\multicolumn{4}{|c|}{$\begin{array}{c}\text { Coeficiente de variação } \\
\text { (\%) } \\
\text { Velocidade }\left(\mathrm{m.s}^{-1}\right)\end{array}$}} & \multirow{3}{*}{$\begin{array}{c}\text { Danos } \\
\text { Físicos } \\
(\%)\end{array}$} \\
\hline & & & & & & & & & \\
\hline & 1,11 & 1,66 & 2,22 & 2,78 & $\mathbf{1 , 1 1}$ & 1,66 & 2,22 & 2,78 & \\
\hline JUMIL/ J-2 S-4 & 54,9 & 45,9 & 43,0 & 41,1 & 65,8 & 76,8 & 83,5 & 77,9 & 2,6 \\
\hline MENEGAZ PA-1250 & 79,3 & 68,5 & 65,0 & 51,7 & 46,0 & 53,8 & 56,5 & 66,5 & 3,9 \\
\hline SANS - 4 linhas & 27,4 & 29,4 & 29,2 & 27,5 & 59,4 & 59,1 & 58,6 & 59,3 & 1,4 \\
\hline BALDAN PAA- 2 & 44,3 & 39,7 & 39,0 & 39,9 & 80,5 & 85,9 & 86,9 & 85,5 & 2,4 \\
\hline MARCHESAN STP-21 & 50,2 & 44,4 & 42,1 & 41,3 & 84,4 & 85,9 & 88,6 & 86,7 & 1,9 \\
\hline MARCHESAN - PTH & - & 49,4 & - & - & - & 68,5 & - & - & 0,9 \\
\hline SEMEATO-2700 & $\mathbf{8 8 , 7}$ & 81,7 & 60,6 & 54,1 & 30,2 & 41,4 & 61,2 & 71,0 & 1,4 \\
\hline BALDAN PAH inclinado & 72,1 & 73,9 & 71,0 & 59,1 & 48,9 & 48,1 & 50,0 & 58,2 & $\mathbf{0 , 7}$ \\
\hline TURBO MAX TM 605 & 90,1 & 89,1 & 88,6 & 89,1 & 33,5 & 334 & 34,8 & 33,4 & $\mathbf{0 , 8}$ \\
\hline
\end{tabular}

Fonte: Kurachi et al. (1993) 
As semeadoras com discos perfurados horizontais, conforme estudo dos mesmos autores, obtiveram as porcentagens mais baixas de espaçamentos aceitáveis (27 a $79 \%$ ), cujos valores médios foram próximos a $45 \%$. Este tipo de disco dosador obteve também os valores mais altos de CV, com variação de $46 \%$ a $88 \%$. Houve, também, diferença significativa quanto aos danos às sementes dependendo do tipo de mecanismo utilizado.

Molin \& Chang (1991) realizando um estudo do desempenho de um dosador de disco vertical, nas velocidades de 1,11, 1,66, 2,22 e 2,78 m.s $\mathrm{s}^{-1}$, obtiveram uma redução de $85,3 \%$ para $52,0 \%$ dos espaçamentos aceitáveis, quando a velocidade foi alterada de $1,11 \mathrm{~m} \cdot \mathrm{s}^{-1}$ para $2,78 \mathrm{~m} \cdot \mathrm{s}^{-1}$. O coeficiente de variação aumentou de $38,4 \%$ para $66,5 \%$.

Pacheco (1994), estudou o efeito de modificações realizadas no tubo condutor de sementes de uma semeadora-adubadora de precisão quanto à uniformidade de distribuição longitudinal de sementes. O trabalho foi desenvolvido sobre bancada em laboratório, variando a velocidade simulada de deslocamento, o comprimento dos tubos condutores de sementes, conformação dos tubos, e a saída das sementes lateral e longitudinal em relação ao eixo central de deslocamento do mecanismo dosador de sementes. As análises dos resultados obtidos identificaram que independente do tratamento, o aumento da velocidade de avanço piorou o desempenho da semeadora estudada. A porcentagem de enchimento das celas diminuiu significativamente com o aumento da velocidade de avanço, porém manteve-se dentro dos limites considerados pelo autor como aceitável (acima de $\mathbf{9 0 \%}$ ). Os melhores resultados foram obtidos na velocidade de $1,39 \mathrm{~m} \cdot \mathrm{s}^{-1}$, saída das sementes no sentido longitudinal, tubos condutores medindo 400 e $200 \mathrm{~mm}$, e curvados $26^{\circ}$ para traz. Os espaçamentos aceitáveis obtidos foram $87,96 \%$ quando utilizou tubos de $400 \mathrm{~mm}$ e $87,93 \%$ com tubos de $200 \mathrm{~mm}$.

Pelos resultados obtidos dos espaçamentos aceitáveis e os coeficientes de variação, observa-se que nas velocidades baixas a eficiência de semeadura é significativamente melhor. Entretanto a capacidade operacional da máquina deve ser 
considerada, encontrando-se uma velocidade compativel com os objetivos agronômicos, obtendo-se eficiência de semeadura e um bom rendimento operacional.

Durante a semeadura podem ocorrer maiores ou menores danos às sementes em função de diferentes mecanismos dosadores. Sementes quebradas ao longo dos cotilédones, ou que sofreram trincas em alguma região vital do embrião, não germinam ou produzem plântulas anormais, com prejuízo irreversível. Segundo Marcos Filho et al. (1985), as sementes sofrem danos mecânicos no processo de semeadura, refletindo diretamente na qualidade das sementes, tomando-as mais suscetíveis ao ataque de pragas e doenças. Por esses motivos, o estudo dos danos mecânicos provocados nas sementes pelos mecanismos dosadores é muito importante na busca de alternativas que preservem a qualidade das mesmas.

O local de impacto nas sementes e o número de vezes que a semente recebe estes impactos são fatores que interferem na intensidade dẹinjúria mecânica em sementes. A suscetibilidade da semente aumenta a cada novo impacto, de maneira que, ao sofrer um novo impacto, com a mesma força o efeito da injúria é maior, segundo Carvalho \& Nakagawa (1980). Entretanto, não se pode exercer nenhum controle sobre eles durante a semeadura, porque é imprevisível saber qual a área da semente que vai ser atingida no momento do impacto nem o número de vezes que os impactos irão ocorrer. Os autores classificam os efeitos da injúria mecânica sobre a qualidade das sementes em efeitos imediatos e efeitos latentes. Efeitos imediatos são aqueles que se fazem sentir logo após a semente ter sido injuriada e se caracterizam como graves apenas quando o grau de injúria é muito grande. Caso a extensão da injúria não seja muito grande a semente pode cicatrizar o tecido danificado e a germinação se processa de forma normal. A cicatrização do tecido injuriado consome tempo e energia, retardando a germinação e provocando a emergência de uma plântula mais fraca. À medida que aumenta a gravidade da injúria, aumentam as exigências em tempo e energia, até o ponto em que a cicatrização se torna impossivel e a germinação não ocorre. Efeitos latentes são os usualmente observados após as sementes injuriadas terem 
permanecido armazenadas no período que vai da colheita até a semeadura. Nesse caso, a injúria mecânica pode ter conseqüências mais sérias, tornando a semente mais suscetivel à deterioração durante o armazenamento.

Boller et al. (1991), avaliaram danos mecânicos e fisiológicos causados por mecanismos dosadores de sementes nas velocidade de plantio de 1,67 e 2,5 m.s. Os autores verificaram que o sistema dosador de disco horizontal de ferro fundido proporciona maior porcentagem de quebra em sementes de soja do que quando equipado com disco de nylon. Não houve diferença significativa, entre os dois discos, no que se refere à porcentagem de emergência e ao vigor das sementes. Os autores verificaram, também, a inexistência de diferença significativa com o aumento da velocidade, nos aspectos referente à percentagem de emergência e ao vigor das sementes. Tanto com disco de ferro como de nylon, ocorreu menor percentagem de quebra a 2,5 m.s $\mathrm{s}^{-1}$ do que a $1,76 \mathrm{~m} . \mathrm{s}^{-1}$, contrariando os resultados relatados por Moreira et al. (1978), os quais demostraram que, com o aumento da velocidade de avanço das semeadoras com dosador de disco perfurado, o índice de danificações mecânicas nas sementes aumentou. Moreira et al. (1978), identificaram também que os danos ocorrem em função da insuficiência de tempo que a semente tem para ser ejetada, ficando presa entre as bordas do orifício do disco e do orifício de saída, o que provoca seu cisalhamento.

Segundo Mantovani et al. (1992), as sementes não realizam o mesmo percurso durante o trajeto entre o mecanismo dosador e o solo, podendo sofrer uma variação do tempo de permanência dentro do tubo. $O$ resultado disso é uma irregularidade de espaçamento entre sementes na linha de plantio. Essa interação entre sementes e o tubo está diretamente relacionada com as características do tubo, do material empregado, diâmetro, comprimento, curvatura e ângulo de inclinação.

Bufton et al. (1974), verificaram que as sementes lançadas no sulco de semeadura do solo, movimentam-se do alvo em relação ao ponto de impacto inicial na superficié, dependendo da velocidade e do angulo que são lançadas pelo tubo de saída 
da forma e peso das sementes e das condições em que se encontra a superfície do solo. A posição final da semente pode variar devido ao rolamento e salteamento no interior do sulco. Os autores concluíram que para sementes de beterraba peletizada e sem peletização, sementes de repolho, cenoura e alface, o deslocamento mínimo das sementes do ponto de impacto no solo ocorreu quando foram lançadas por tubos com inclinação de 75 a 85 graus em relação à superfície.

Tourino e Klingnsteiner (1983), testando semeadoras sobre bancada para estudar dosador tipo disco perfurado, avaliaram a distribuição de sementes de soja sobre esteira. Foi avaliada a uniformidade de distribuição de sementes, em função da velocidade de deslocamento, nível de sementes no depósito, altura de queda das sementes sobre a esteira, além do tipo de mecanismo dosador, disco perfurado de formato redondo com $\mathbf{4 8}$ furos, para liberação de uma semente por vez e furos oblongos com 24 e 16 perfurações para liberação de mais de uma semente por vez. A análise dos resultados obtidos permitiram concluir que o fator que mais influenciou a uniformidade de distribuição de sementes foi o tipo de liberação. A liberação de apenas uma semente por furo com disco de $\mathbf{4 8}$ furos proporcionou uma uniformidade de distribuição significativamente superior às demais. $\mathrm{O}$ nível de sementes no reservatório não influenciou a uniformidade de distribuição de sementes. A velocidade de $0,75 \mathrm{~m} . \mathrm{s}^{-1}$, gerou uma melhor distribuição que a velocidade de $1,11 \mathrm{~m} \cdot \mathrm{s}^{-1}$. Não foi observada a influência da altura de queda de sementes sobre a uniformidade de distribuição. Provavelmente a diferença de altura de $128 \mathrm{~mm}$ não tenha sido suficiente para causar alguma alteração.

\subsection{Influência da eficiência de semeadura e população de plantas na produtividade}

Levantamentos realizados pela EMPASC/ACARESC, identificaram que a população de milho nas propriedades agrícolas da região Oeste de Santa Catarina, no momento da colheita, situa-se entre 30 e 50 mil plantas.ha ${ }^{-1}$ (Molin \& D'Agostini, 
1996). Valores de população de plantas abaixo das recomendações agronômicas, foram encontrados também por Mantovani et al. (1992), que, em avaliações de semeadoras convencionais obtiveram populações na faixa de 35 a 42 mil plantas por hectare em oito das nove semeadoras avaliadas. As semeadoras estudadas dispunham de dosadores tipo disco vertical pneumático, disco perfurado inclinado e horizontal. As velocidades testadas foram $1,4,1,8$ e $2,1 \mathrm{~m} \cdot \mathrm{s}^{-1}$. Uma única semeadora obteve população de plantas acima de 50 mil por hectare nas três velocidades trabalhadas.

Cavaglioni et al. (1991), realizaram um levantamento no Estado do Paraná e identificaram problemas de danos e má distribuição de sementes de feijão e milho. Os dados obtidos mostraram que $6,4 \%$ das propriedades da região central, $41,4 \%$ da região sudoeste, e $13,8 \%$ da região nordeste, apresentavam tais problemas. No estudo foram identificados, também, problemas de distribuição de sementes de soja em 14,2\% das propriedades e trigo em $9,4 \%$ das propriedades no norte e oeste do Estado.

A desuniformidade da distribuição longitudinal de sementes pode reduzir a produtividade da cultura, tanto pela competitividade entre plantas por água, nutrientes, luminosidade bem como pela competição por espaço vital ou mau aproveitamento do mesmo. Isto ocorre em função do acúmulo de plantas em alguns trechos e falhas em outros locais da fileira de plantio (Delafosse, 1986). Segundo o autor a falta de regularidade de espaçamento entre plantas pode resultar em perdas superiores a $15 \%$ na cultura de milho, a $35 \%$ na cultura de girassol e a $10 \%$ na cultura de soja.

Williams et al. (1968), concluíram que com o aumento da densidade populacional de plantas, aumenta-se também a competiçăo por luz entre as folhas, decorrente do sombreamento mútuo entre elas em condições normais de suprimento de água e nutrientes.

Duncan et al. (1958), afirmam que a redução da produtividade de milho, após atingir o teto máximo decorrente do aumento da população, se deve, 
principalmente, ao número de plantas estéreis, caracterizando-se por plantas sem espigas ou espigas sem grãos.

Esechie (1992), estudando os efeitos da densidade no desenvolvimento e produção de milho em lavoura irrigada, concluiu que o LAI, (Índice de Área Foliar), com o aumento de população de plantas por hectare aumentou a proporção de plantas estéreis e reduziu o peso de grãos por espiga. $O$ autor obteve também resultados de produtividade de milho e características morfológicas das espigas, conforme apresentados na Tabela 5.

Tabela 5. Produtividade e características morfológicas das espigas de milho irrigado nas cultivares Eperon e Challenger.

\begin{tabular}{|c|c|c|c|c|c|c|c|}
\hline $\begin{array}{c}\text { Milho } \\
\text { Cultivar }\end{array}$ & $\begin{array}{c}\text { População } \\
\text { plantas.ha' }^{-1}\end{array}$ & $\begin{array}{c}\text { Índice } \\
\text { de } \\
\text { espigas }\end{array}$ & $\begin{array}{c}\text { Peso/ } \\
\text { espiga } \\
\text { (kgf) }\end{array}$ & $\begin{array}{c}\text { Diâmetro/ } \\
\text { espiga } \\
\text { (cm) }\end{array}$ & $\begin{array}{c}\text { Comprimento } \\
\text { espiga } \\
\text { (cm) }\end{array}$ & $\begin{array}{c}\text { Sementes } \\
\text { por } \\
\text { espiga }\end{array}$ & $\begin{array}{r}\text { Produti- } \\
\text { vidade } \\
\left(\text { t. } \text { ha }^{-1}\right)\end{array}$ \\
\hline Eperon & 24.000 & 1,00 & 0,13 & 3,19 & 14,7 & 386 & 2,27 \\
\hline Eperon & 48.000 & 0,99 & 0,14 & 3,31 & 15,1 & 355 & 3,48 \\
\hline Eperon & 74.000 & 0,81 & 0,10 & 3,14 & 14,2 & 372 & 2,45 \\
\hline Challenger & 24.000 & 0,81 & 0,13 & 3,11 & 15,7 & 401 & 2,09 \\
\hline Challenger & 48.000 & 0,96 & 0,12 & 3,28 & 14,9 & 384 & 3,24 \\
\hline Challenger & 74.000 & 0,77 & 0,09 & 3,01 & 15,8 & 373 & 2,21 \\
\hline
\end{tabular}

Fonte: Esechie (1992)

$\mathrm{O}$ aumento de população alterou significativamente o número de espigas por planta, variando de 77 a 100 espigas a cada 100 plantas. O peso variou também de 0,09 a 0,14 kgf/espiga, assim como as demais características morfológicas (diâmetro, comprimento e número de sementes). A produtividade, na população de 48 mil plantas por hectare foi superior às populações de 24 e 74 mil plantas. ha ${ }^{-1}$, nas duas variedades estudadas. 
Nielsen (1995), realizou ensaios em 22 fazendas, de três estados dos Estados Unidos, e analisou o efeito da velocidade de semeadura de milho na população final de plantas, uniformidade de semeadura e produtividade de grãos por hectare. A semeadura foi realizada nas velocidades de $1,78,2,23,2,67$ e 3,12 m.s ${ }^{-1}$. O autor constatou redução da população em 1.302 plantas.ha $^{-1}$, em uma das fazendas, a cada aumento da velocidade da máquina de $0,45 \mathrm{~m} \cdot \mathrm{s}^{-1}$, e aumento de população de 512 a 4.724 plantas.ha ${ }^{-1}$, a cada aumento de velocidade de $0,45 \mathrm{~m} . \mathrm{s}^{-1}$, em nove fazendas das 22 estudadas. Ocorreu uma redução da produtividade em 5 fazendas, diminuindo 107,5 a $266,0 \mathrm{~kg} \cdot \mathrm{ha}^{-1}$, a cada aumento de velocidade de $0,45 \mathrm{~m} \cdot \mathrm{s}^{-1}$.

Pozar \& Zago (1990), estudaram os efeitos gerais do aumento da densidade de plantio sobre a produção de grãos e silagem. Variaram a população de sete híbridos, obtendo os resultados em produção de espigas, matéria seca e dimensionamento dos componentes da planta (Tabela 6). Os autores citam, ainda, que o aumento da densidade de plantas modifica o padrão de translocação de assimilados na planta e que, em condições normais, durante o florescimento ou logo após, a espiga atua como o centro polarizador do movimento dos carboidratos na planta. Citam, também, que, com o aumento da população de plantas por área, o colmo e as folhas passam a ser os principais órgãos de armazenamento de assimilados.

De uma maneira geral, os componentes da planta que interferem na produção de grãos, foram afetados significativamente quando a densidade foi maior do que 55.000 plantas por hectare. $O$ índice de espigas diminuiu de 1,12 para 0,76 , quando a população passou de 30 mil para 105 mil plantas.ha ${ }^{-1}$, e o número de grãos na fileira, reduziu de 40,4 para 30,1. O aumento da população de plantas provocou aumento da porcentagem de plantas acamadas, e principalmente, de plantas quebradas. A maior produtividade média de grãos ocorreu na densidade de 55.000 plantas.ha $^{-1}$ e foi, significativamente, maior do que as outras, que não diferiram entre si. 
Tabela 6. Resultados da avaliação de sete híbridos de milho em quatro densidades de plantio. Campinópolis - MG (1989/1990).

\begin{tabular}{|c|c|c|c|c|c|}
\hline Populacão de plantas.ha $^{-1}$ (1000) & 30 & 55 & 80 & 105 & CV (\%) \\
\hline Produção de massa verde (t.ha $\left.{ }^{-1}\right)$ & $46,1 b^{*}$ & $58,1 \mathrm{ab}$ & $63,2 \mathrm{a}$ & $67,4 \mathrm{a}$ & 6,50 \\
\hline Produção de matéria seca- (t.ha $\left.{ }^{-1}\right)$ & $11,7 \mathrm{c}$ & $14,6 \mathrm{~b}$ & $15,3 \mathrm{ab}$ & $16,1 \mathrm{ab}$ & 10,16 \\
\hline Espiga na matéria seca total (\%) & $30,8 \mathrm{a}$ & $29,1 \mathrm{a}$ & $24,7 \mathrm{~b}$ & $22,8 \mathrm{~b}$ & 10,95 \\
\hline $\begin{array}{l}\text { Produtividade de grãos a } 13 \% \text { de umidade } \\
\left(\text { t.ha }^{-1}\right)\end{array}$ & $5,10 \mathrm{~b}$ & 5,85 a & $5,40 \mathrm{~b}$ & $5,37 \mathrm{~b}$ & 7,89 \\
\hline Índice de espiga & $1,12 \mathrm{a}$ & $0,95 \mathrm{~b}$ & $0,88 \mathrm{c}$ & $0,76 \mathrm{~d}$ & 8,72 \\
\hline Plantas acamadas na colheita (\%) & $2,7 \mathrm{a}$ & $0,6 \mathrm{a}$ & 5,4 a & 3,0 a & 203,76 \\
\hline Plantas quebradas na colheita (\%) & $25,5 \mathrm{a}$ & 47,2 a & $56,0 \mathrm{a}$ & $57,9 \mathrm{a}$ & 32,41 \\
\hline
\end{tabular}

* Medias na horizontal com a mesma letra, não diferem entre si pelo teste de Tuckey a $5 \%$ de probabilidade.

Fonte: Pozar e Zago (1990)

Leite (1973), estudando a influência da variação da distância entre linhas na cultura do milho, de $1,00 \mathrm{~m}$ para $0,75 \mathrm{~m}$, constatou $8,4 \%$ de aumento na produção. Este aumento de produtividade no espaçamento de $0,75 \mathrm{~m}$ entre fileiras foi constatado até a população de 91.000 plantas por hectare. Acima dessa população, o milho apresentou deficiência no crescimento e formação da planta, ocorrendo queda na produtividade. Segundo o autor, para se obter uma boa produção de milho é necessário que a radiação solar seja suficiente, sem ser prejudicada por um elevado adensamento de plantas. Isso resultaria na competição entre plantas pela absorção da radiação solar.

O milho, segundo Russel (1972), difere das outras culturas no que se refere à compensação foliar quando a densidade for baixa, porque não se ramifica e não perfilha. Portanto, apresenta uma situação particular, devido à pouca plasticidade foliar e reprodutiva e, com isso, não consegue compensar um baixo número de plantas.por hectare. Outro fator importante é que em populações muito elevadas por unidade de área, ocorre uma drástica redução do número de grãos por metro quadrado, 
porque a espiga é um componente auxiliar, uma reserva da planta, e portanto de prioridade secundária para a planta.

Contrariando esses resultados, Rizardi et al. (1994), concluíram em seu trabalho que não houve diferença na produtividade de milho, independentemente dos espaçamentos utilizados entre fileiras $(0,7$ ou $0,9 \mathrm{~m})$. Concluíram que a cultura do milho foi capaz de compensar a desuniformidade de espaçamento entre plantas, não ocorrendo diferença significativa na produtividade, mantida a mesma população de plantas por hectare.

\subsection{Parâmetros para medir a eficiência da semeadura}

Para semeadoras de precisão de culturas que requerem uma distância uniforme entre plantas, como é o caso do milho, feijão, girassol, algodão e soja, a capacidade de distribuição das sementes distanciadas uniformemente na linha é uma característica desejável e um fator primordial na avaliação do desempenho da máquina, (Kachman \& Smith, 1995). A distância entre plantas na fileira é influenciada por uma série de fatores, dentre eles as sementes que caem juntas, as falhas na deposição de sementes e as que não germinam. Segundo esses autores, os parâmetros média e desvio padrão não são indicadores precisos para avaliar a eficiência das semeadoras. Os autores sugerem o cálculo da precisão para medir a eficiência da semeadura entre os espaços considerados aceitáveis, isto é os espaços entre $0,5 . X_{\text {ref e }} 1,5 . X_{\text {ref. A precisão é igual }}$ ao desvio padrão dos espaçamentos aceitáveis, dividido pela distância de semeadura de referência estabelecida para a cultura. Quanto menor o valor da precisão obtido, maior quantidade de espaços medidos próximos ao espaçamento de referência estabelecido para a cultura. Valor de $50 \%$ é o valor teórico máximo para a precisão e indica picos distanciados da média, 50\% na extremidade à direita e 50\% na extremidade à esquerda da média estabelecida. O valor de precisão de $29 \%$ indica que os espaços estão distribuídos uniformemente dentro da faixa dos aceitáveis. 
Molin et al. (1996), estudou uma semeadora de milho em covas para semeadura direta, que consiste em uma roda composta por 15 pontas, radialmente distribuídas em torno de 1 anel metálico, utilizando um dosador de sementes a vácuo. Foram realizados testes em bancada nas velocidades de 1,2 e 3 m.s ${ }^{-1}$ e no campo na velocidade de $2 \mathrm{~m} . \mathrm{s}^{-1}$ em sistema de semeadura direta sobre diferentes tipos e quantidade de palhada. Os testes de bancada com a semeadora resultaram em um índice de aceitáveis entre $98,0 \%$ e 95,6\%. Os resultados de precisão obtidos pelo autor foram entre $17,4 \%$ e $18,7 \%$, quando testada em bancada. Transportando para o campo, trabalhando a $2 \mathrm{~m} . \mathrm{s}^{-1}$, os resultados da precisão foram melhor que os de laboratório, variando de $10,3 \%$ a $12,8 \%$.

O impacto da taxa de emergência sobre o índice de precisão é pequeno, porque a precisão é calculada considerando-se somente as plantas que estão dentro da faixa dos espaços aceitáveis $\left(0,5\right.$ a $\left.1,5 \mathrm{X}_{\text {ref }}\right)$. Sendo assim os espaços maiores, resultantes das sementes que não germinaram, não entram no cálculo.

Segundo critério adotado por Kurachi et al. (1989), as populações de plantas são distribuídas em classes de freqüência, com amplitude de $0,1 X_{\text {ref. sendo que }}$ o valor de referência é recomendado, agronomicamente, para cada espécie de planta conforme características da cultura. Para os autores os coeficientes de variação são calculados sobre toda a população de espaçamentos, não sendo portanto somente dos aceitáveis como na precisão, e o valor de $X_{\text {ref }}$ deve ser mantido pelas seguintes razões: $\left.1^{a}\right)$ Atender às necessidades agronômicas. Isto porque uma máquina pode semear com um coeficiente de variação próximo ou igual a zero, porém com espaçamentos discrepantes em relação às características desejáveis para a cultura. Neste caso, avaliando-se somente sob os aspectos de eficiência da máquina seria perfeito, porém, do ponto de vista agronômico, seria indesejável. $2^{a}$ ) O espaçamento referência teórico ( $X_{\text {reff }}$ teórico), dependendo das opções oferecidas pelo fabricante quanto às regulagens básicas do mecanismo dosador, pode assumir valores diferentes para uma máquina, 
quase sempre variáveis de uma semeadora para outra, tornando impossível a comparação de populações de espaçamentos distribuídos em intervalos com amplitudes desiguais.

Quando o cálculo do coeficiente de variação é realizado levando-se em consideração apenas parte da população, estará sempre sujeito à crítica pela razão de não refletir a variação total da amostra analisada.

Tourino e Klingsteiner (1983), adotaram critérios para avaliação de semeadoras adubadoras de precisão, considerando ótimo o desempenho da semeadora que distribuir 90 a 100\% das sementes na faixa de espaçamentos aceitáveis; bom desempenho, de 75 a $90 \%$; regular, de 50 a $75 \%$ e; insatisfatório abaixo de $50 \%$.

Coelho (1997), levando em consideração a heterogeneidade do nível tecnológico das semeadoras-adubadoras de precisão no Brasil e da necessidade de parâmetros para certificação de semeadoras-adubadoras, estabeleceu requisitos de regularidade de distribuição longitudinal de sementes e adotou critérios dos espaçamentos aceitáveis entre sementes e o coeficiente de variação para testes em laboratório, como pode-se observar na Tabela 7.

Tabela 7. Parâmetros de avaliação para semeadoras de precisão para testes em laboratório.

\begin{tabular}{lcc}
\hline Tipo de mecanismo dosador & $\begin{array}{c}\text { Valores mínimos de } \\
\text { espaçamentos aceitáveis } \\
(\%)\end{array}$ & $\begin{array}{c}\text { Valores máximos do } \\
\text { Coeficiente de variação }\end{array}$ \\
\hline Discos perfurados horizontais & $\mathbf{6 0 , 0}$ & $(\%)$ \\
Dedos preensores & $\mathbf{7 5 , 0}$ & $\mathbf{5 0 , 0}$ \\
Discos verticais pneumáticos & $\mathbf{9 0 , 0}$ & $\mathbf{4 0 , 0}$ \\
\hline
\end{tabular}

Fonte: Coelho (1997) 
Pasqua et al. (1996), avaliando o desempenho de uma semeadora adubadora no campo, levantaram os indicadores de qualidade do plantio de milho, (número de sementes por metro no sulco, espaçamento entre sementes, profundidade de colocação das sementes e espaçamento entre linhas de emenda) efetuado por uma semeadora equipada com mecanismo dosador tipo dedos preensores a $1,17 \mathrm{~m} \cdot \mathrm{s}^{-1}$. Para tanto utilizaram o método dos 75 pontos, ( 2 metros lineares por ponto), levantados aleatoriamente, para avaliação de cada indicador de qualidade. Encontraram espaçamentos múltiplos com menos de $2,0 \mathrm{~cm}$ entre sementes, e espaçamentos falhos, de até $51 \mathrm{~cm}$ entre sementes. $O$ valor percentual dos espaçamentos aceitáveis foi $62,5 \%$, o que classifica esta semeadora como regular, segundo Tourino \& Klingsteiner (1983). 


\section{MATERIAL E MÉTODOS}

\subsection{Material}

\subsection{1. Área experimental}

Os trabalhos de campo foram desenvolvidos na Fazenda Areão, área experimental do Departamento de Engenharia Rural, da Escola Superior de Agricultura "Luiz de Queiroz" da Universidade de São Paulo, em Piracicaba, Estado de São Paulo, cujas coordenadas geográficas são: $22^{\circ} 42^{\prime} 30^{\prime \prime}$ de Latitude Sul, $47^{\circ} 38^{\prime} 0^{\prime \prime}$ de Longitude Oeste e Altitude de $546 \mathrm{~m}$.

O clima da região é o Cwa, de Köppen, mesotérmico, com média anual de $1.297 \mathrm{~mm}$ de precipitação, umidade média relativa de $69 \%$ e temperatura média de $20,8^{\circ} \mathrm{C}$.

A área experimental apresenta uma superfície aproximada de 0,6 hectares, declividade de $\mathbf{8 , 5 \%}$ e face de exposição Sudeste. O solo é classificado como Terra Roxa estruturada (Alfisol), série "Luiz de Queiroz", com predominância da fração argila na camada de $0-25 \mathrm{~cm}$.

No momento da semeadura o solo estava coberto por uma massa de 3,6 t.ha $^{-1}$ de palha seca de Sorghum halephense e Crotalaria juncea, cobrindo $85 \%$ da superficie do terreno.

\subsubsection{Caracterização das máquinas utilizadas nos experimentos de campo}

$\mathrm{Na}$ instalação da cobertura do solo, manejo da palha, semeadura e tratos 
culturais da cultura de milho, foram utilizadas as seguintes máquinas:

- Trator Massey Ferguson 275, tração dianteira auxiliar, 75 cv de potência no motor.

- Pulverizador de barras modelo J-600, montado, capacidade 600 litros, bicos tipo leque 110.04, marca Jato S/A.

- Grade aradora, com 18 discos, diâmetro 0,7 m, marca Baldan.

- Grade niveladora, com 36 discos de diâmetro 0,45 m, marca Tatu.

- Aplicador de sementes e fertilizantes a lanço marca Vicon, montado, acionado pela tomada de potência do trator.

- Triturador com facas giratórias, modelo Triton, acionado pela tomada de potência do trator.

- Semeadora de precisão JUMIL-2040, com mecanismo de distribuição de sementes tipo disco perfurado horizontal.

- Semeadora de precisão EXATA Air 2900 - Jumil/SA, com mecanismo de distribuição de sementes tipo disco vertical, pneumática.

A semeadora JUML-2040, possui discos dosadores tipo perfurados horizontais, com um platô na parte superior, onde está fixado o mecanismo dosador, e um disco de sustentação onde desliza o disco dosador com as sementes alojadas nas celas, como pode-se observar na Figura 2. Possui um rasador metálico duplo, pressionado por molas, mantendo-se próximo da superfície do disco perfurado, para eliminar o excesso de sementes das celas antes que estas atinjam o orificio de saída. Após as sementes passarem pelo mecanismo razador, são retiradas das celas pelo mecanismo ejetor, constituído por um rotor de plástico. O rotor pressiona individual e ininterruptamente as sementes nos orifícios dos discos, não permitindo que fiquem sementes alojadas nas celas (Gadanha et al. 1991). 


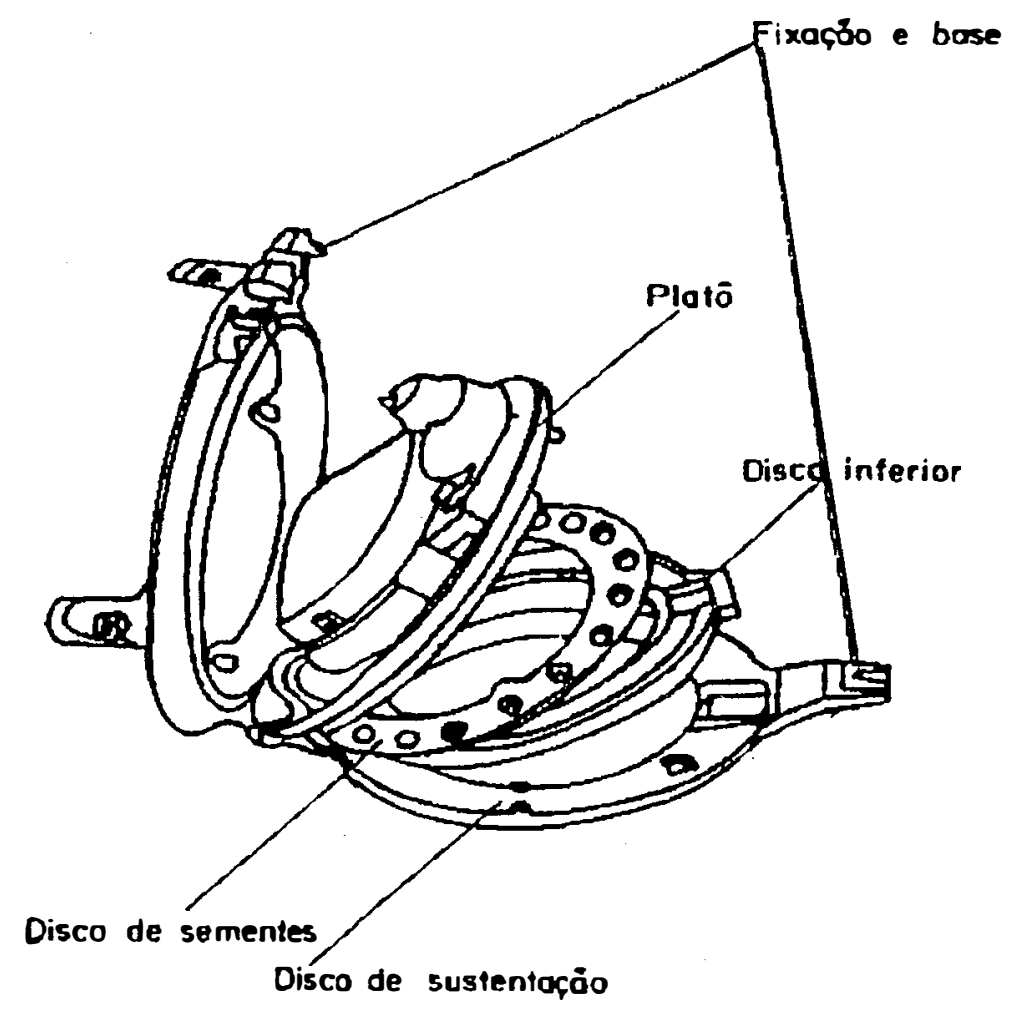

Figura 2. Componentes do sistema dosador de sementes tipo disco perfurado.

Ogliari (1990).

Os discos dosadores de sementes são acionados pelas rodas pneumáticas compactadoras, ligadas em um sistema de transmissão do movimento, composto de engrenagens cônicas e correntes de articulação desmontável, como pode-se observar na Figura 3.

A regulagem da quantidade de sementes por metro linear é obtida pela troca das engrenagens da corrente, variando-se a relação de transmissão motriz/motora, ou então pela troca de discos dosadores. A quantidade de sementes é calculada conforme a quantidade de plantas desejadas por hectare, levando-se em consideração o espaçamento entre fileiras, germinação das sementes, pureza das sementes, enchimento do disco dosador e patinamento da roda compactadora. 
A reposição do solo na linha de semeadura é realizado por dois discos metálicos posicionados logo atrás do sistema de deposição de sementes, com variação do ângulo de ataque, permitindo que as sementes fiquem encobertas. $\mathrm{O}$ adensamento do solo ao redor das sementes é realizado por rodas dentadas com bandas de borracha, que além de adensar o solo sobre as sementes, fazem o acionamento de engrenagens, correntes, pinhão e coroa do sistema de distribuição, e a limitação da profundidade de semeadura. (Balastreire, 1990).

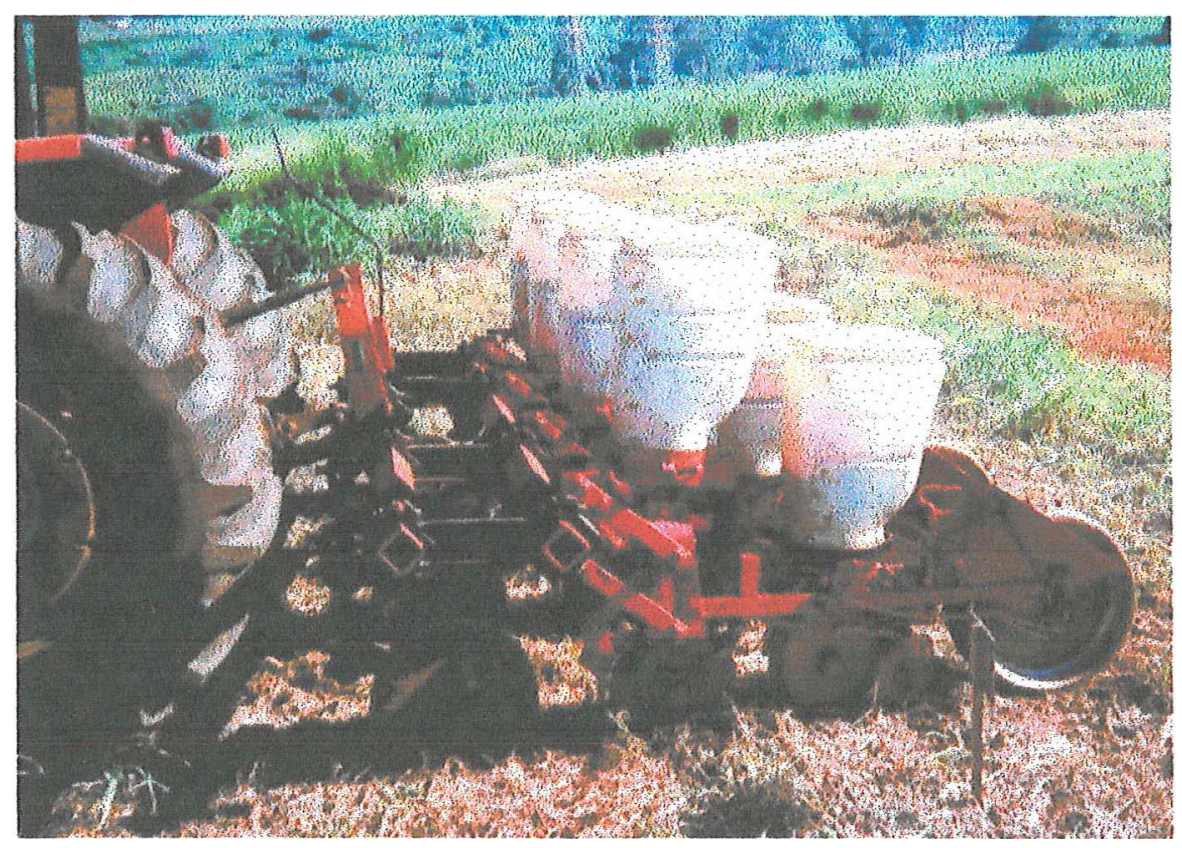

Figura 3. Vista lateral da semeadora-adubadora de precisão 2040-JUMIL AS, adaptada para semeadura direta.

Os tubos condutores de sementes são de polietileno, formato quadrangular na parte superior próximo ao dosador e arredondado na saída das sementes rente ao solo. São retos e lisos, externa e internamente.

Os depósitos de sementes são de polietileno, lisos, de formato quadrangular, afunilado na base e com suporte interno para aliviar a pressão das sementes sobre os discos dosadores. 
Neste trabalho utilizou-se discos de plástico e discos metálicos, fornecido pela JUMIL S/A. O diâmetro dos furos dos discos foram dimensionados em função da máxima dimensão das sementes empregadas no experimento. Segundo Kepner \& Bainer (1972), é recomendável que o diâmetro para as furos dos discos dosadores perfurados, seja $10 \%$ superior à máxima dimensão das sementes utilizadas. Os discos foram perfurados na fábrica com diâmetro dos furos de $11,2 \mathrm{~mm}$, atendendo tais recomendações.

O disco dosador gira sobre um disco inferior, de espessura menor, com a função de eliminar excesso de folgas entre o disco de sementes e o platô. Neste estudo foi utilizado um disco inferior de espessura de $3 \mathrm{~mm}$. As sementes foram arrastadas pelo disco de sementes até a saída no tubo de descarga, deslizando sobre o disco inferior e, depois, ejetadas.

A máquina dispõe de mecanismo de corte da palha e rompimento do solo, tipo disco liso, para permitir a semeadura direta na palha.

As dimensões e características das máquinas e dos mecanismos dosadores estão descritas na Tabela 8, onde pode-se observar as diferenças nos sistemas de apreensão de sementes e a similaridade nos mecanismos de corte e sulcamento do solo.

A semeadora EXATA AIR 2900 (Jumil/SA), dispõe de discos dosadores de sementes tipo vertical, acionado pela roda motriz localizada na parte inferior da semeadora-adubadora. Esta máquina possui um sistema de engrenagens cônicas e correntes de articulação desmontável para permitir a variação do número de sementes por metro linear. Existe uma variação no diâmetro e número de orifícios do disco dosador, para atender aos diferentes formatos e tamanho das sementes utilizadas. A máquina possui um controlador de profundidade independente, constituído por 2 rodas localizadas logo atrás dos discos de semeadura, reguladas por um comando mecânico, permitindo a semeadura na profundidade exigida pela cultura a ser implantada. Para 
adensamento do solo ao redor da semente e reposição do solo no sulco de semeadura, a máquina dispõe de um compactador flutuante em "V".

A aderência das sementes nos furos dos discos dosadores ocorre pela sucção formada por um fluxo de ar que atravessa cada orificio dosador, para a captura das sementes. Com o giro do disco, as sementes aderidas nos orificios, passam pelo tubo de saída, e devido a ausência de fluxo nesse local, são liberadas projetando-se até o sulco no solo.

O mecanismo pneumático de sucção é acionado pela TDP (tomada de potência) do trator, à rotação de $540 \mathrm{rpm}$ (rotações por minuto). Para a permanência de apenas uma semente por orificio, o mecanismo dosador dispõe de um seletor metálico posicionado lateralmente e próximo aos furos do disco, retirando as sementes excedentes sem causar efeito abrasivo ou de impacto nas sementes (Figuras 4 e 5 ).

Os tubos condutores de sementes são de polietileno, formato quadrangular próximo ao dosador e arredondado na saída da semente, rente ao solo. São lisos, externa e internamente, com um ângulo de inclinação para trás na extremidade próxima ao solo. 


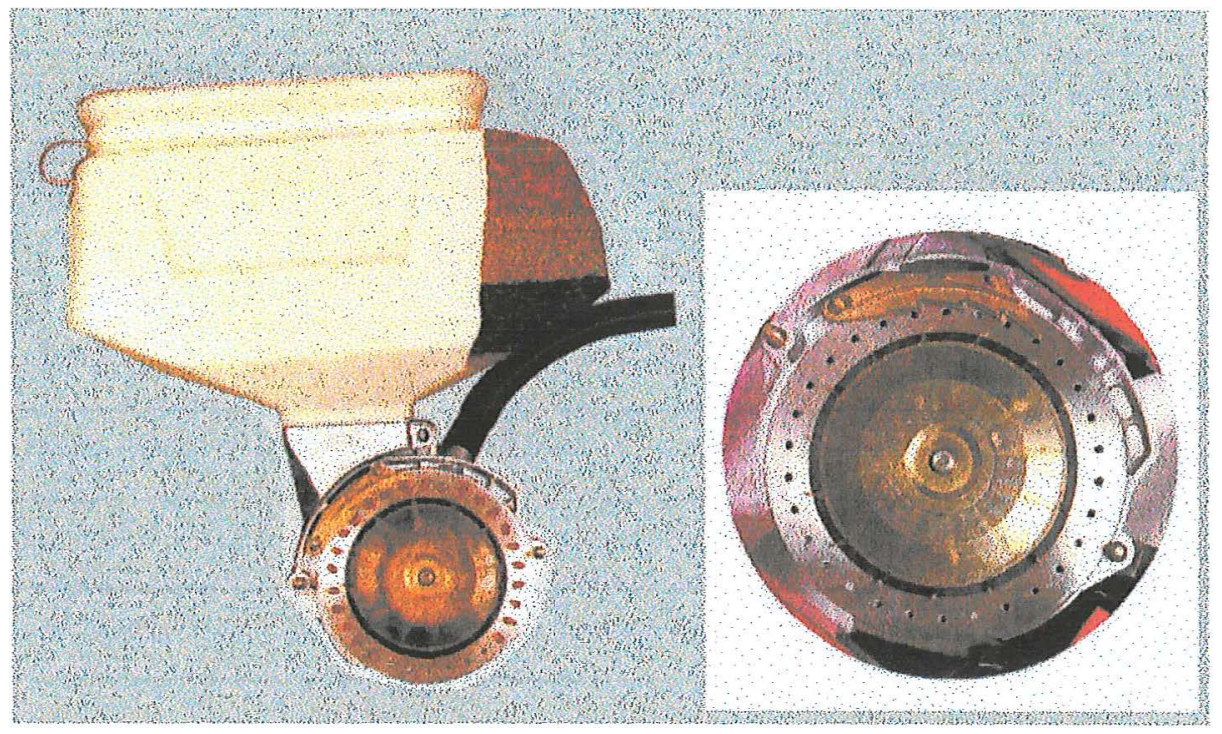

Figura 4. Sistema dosador pneumático da semeadora adubadora Exata da marca Jumil, utilizado na semeadura nos experimentos (esquerda). Detalhe do seletor posicionado junto aos orifícios (direita) (Catálogo Jumil).

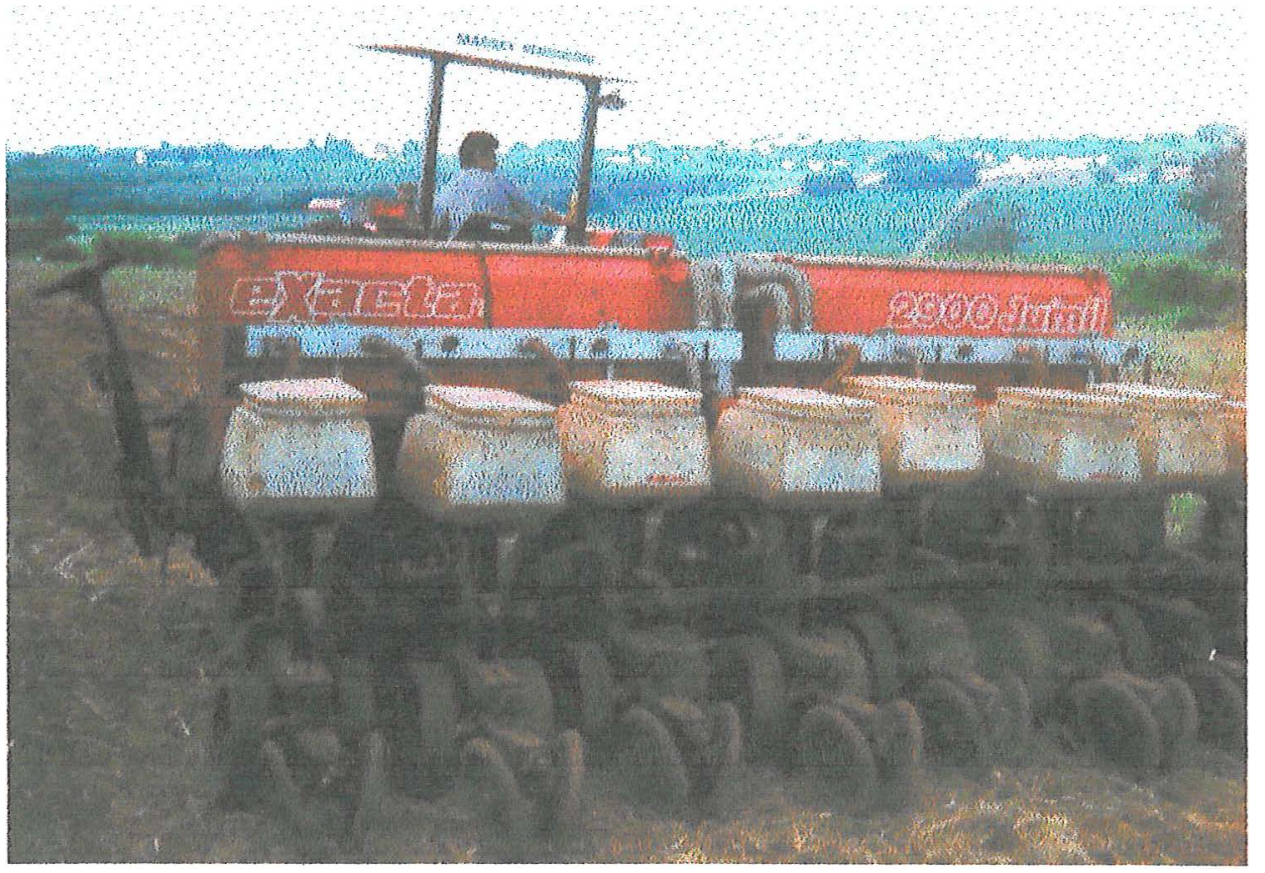

Figura 5 - Semeadora de precisão tipo pneumática utilizada no experimento. 
Tabela 8. Caracteristicas técnicas e dimensionais dos mecanismos das máquinas utilizadas no trabalho.

\begin{tabular}{cccccccccc}
\hline Semeadoras & $\begin{array}{c}\text { Tipo de } \\
\text { disco } \\
\text { Dosador }\end{array}$ & $\begin{array}{c}\text { Número de } \\
\text { furos } \\
\text { do disco }\end{array}$ & $\begin{array}{c}\text { Diâmetro } \\
\text { dos furos } \\
(\mathrm{mm})\end{array}$ & $\begin{array}{c}\text { Espessura } \\
\text { dos discos } \\
(\mathrm{mm})\end{array}$ & $\begin{array}{c}\text { Tubos condutores de } \\
\text { sementes }\end{array}$ & $\begin{array}{c}\text { Diâmetro dos } \\
\text { discos (mm) }\end{array}$ & $\begin{array}{c}(\mathrm{mm}) \\
\left(\mathrm{mm}^{2}\right)\end{array}$ & \\
\hline S1 & Horizontal & 22 & 11,6 & 5,8 & 440 & 875 & 350 & 420 & 320 \\
S2 & Vertical & 60 & 3,5 & 2 & 420 & 2200 & 500 & 430 & 350 \\
\hline
\end{tabular}

S1 - Semeadora adubadora de precisão, 4 linhas, com dosador tipo disco dosador perfurado.

S2 - Semeadora adubadora de precisão, 8 linhas, com dosador tipo disco vertical pneumático por sucção.

$\mathrm{C}^{\mathbf{1}}$-Comprimento total dos tubos condutores da semente do mecanismo dosador até a saída rente ao solo.

$\mathrm{Ss}^{2}$-Área superior do tubo condutor de sementes, (local próximo ao mecanismo dosador)

$\mathrm{Si}^{3}$-Área inferior do tubo condutor de sementes, (local próximo ao solo)

** -Discos de corte rompedores do solo e de corte da palha tipo liso

* -Discos múltiplos lisos para abertura do sulco das sementes

\subsubsection{Caracterização da bancada de testes}

Para determinação dos danos provocados às sementes e enchimento de célas, utilizou-se uma bancada de testes com os seguintes componentes, conforme Figura 6:

- Mesa de madeira medindo 2,0 x 1,2 m, equipada com motor elétrico com variador mecânico de rotação, conjunto de polias com variador para 8 velocidades, caixa seletiva de 4 velocidades, conforme Figura 6.

- Unidade da semeadora de precisão tipo disco perfurado horizontal, com depósito de sementes, disco perfurado de ferro e de plástico, anel de $3 \mathrm{~mm}$, pinhão, coroa, e tubo de saída das sementes fixada na bancada de teste.

- Sensor ótico com capacidade de registro de 60 pulsos por giro, fixado no eixo do pinhão da unidade de semeadura e no cronodômetro, fixado na mesa.

- Cronodômetro eletrônico, conectado a um acumulador de corrente del2 V e no cabo terminal do sensor ótico, fabricação DER - ESALQ. 


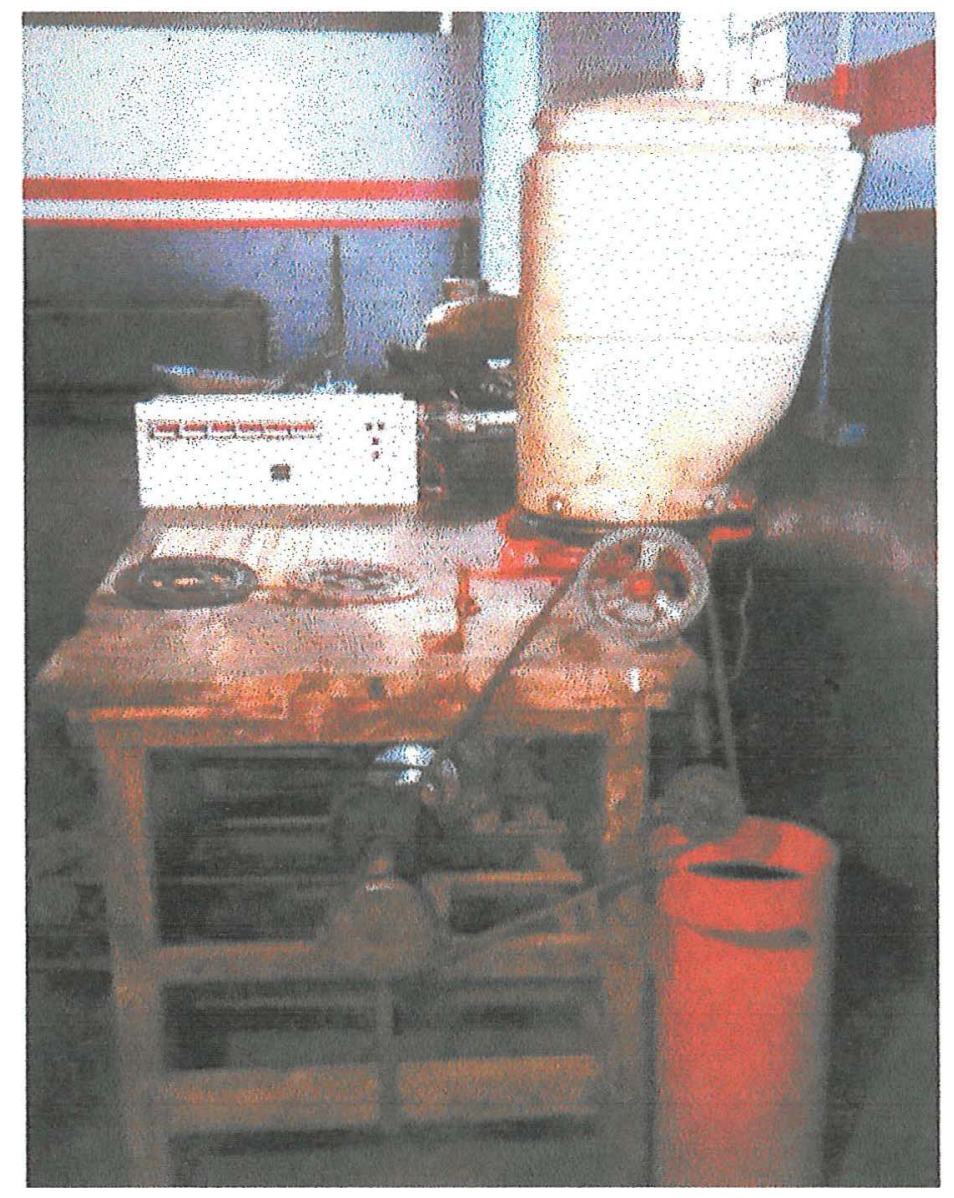

Figura 6. Bancada de testes para avaliação dos danos às sementes e enchimento das celas (Departamento de Engenharia Rural, ESALQ-USP).

\subsubsection{Equipamentos utilizados no laboratório de sementes}

- Germinador BURROWS, Burrows equipamentos eletrônicos CO, com variação de temperatura de $0-110^{\circ} \mathrm{C}$, fundo de escala $1^{\circ} \mathrm{C}$.

- Estufa incumbadora para B. ${ }^{\circ}$ D. FANEM SP. Brasil. Variação de temperatura de $-10^{\circ} \mathrm{C}$ a $50^{\circ} \mathrm{C}$, fundo de escala $1^{\circ} \mathrm{C}$.

- Balança BG-4400, Eletrônica Gehaka, capacidade mínima 0,25g. capacidade máxima $4200 \mathrm{~g}$, fundo de escala $0,01 \mathrm{~g}$.

- Estufa retilínea FANEM Ltda, variação de $0-120^{\circ} \mathrm{C}$, fundo de escala $0,5^{\circ} \mathrm{C}$ 


\subsection{Métodos}

\subsubsection{Formação e avaliação da cobertura do solo}

Antes da implantação da cobertura vegetal, a área experimental encontrava-se em pousio e infestada de capim massambará (Sorghum halepense), em fase de formação da panícula. Em Novembro de 1996, realizou-se uma gradagem, com a grade aradora, a $15 \mathrm{~cm}$ de profundidade. Distribuiu-se $100 \mathrm{~kg}$ do adubo fórmula 4-2012, e $80 \mathrm{~kg}$ de sementes de Crotalaria juncea, tipo B, de baixa germinação, utilizandose um distribuidor pendular tratorizado, e posteriormente incorporou-se o adubo e a sementes com uma grade niveladora.

Antes do final do ciclo da crotalária, realizou-se o manejo da cobertura verde, no estádio de formação de vagem da crotalária e formação de panícula do capim massambará, utilizando-se um triturador de facas giratórias, acionado pela TDP do trator e regulado para corte da vegetação a $12 \mathrm{~cm}$ acima do solo.

Dez dias antes da semeadura do milho, aplicou-se $0,82 \mathrm{~kg} / \mathrm{ha}$ de princípio ativo de Glyphosate, utilizando-se o pulverizador de barras acoplado ao trator MF-275, com um volume de calda de $3501 . \mathrm{ha}^{-1}$, para o controle de plantas daninhas presentes na área experimental.

Coletou-se, aleatoriamente, dez amostras da palha distribuída sobre o solo da área experimental, utilizando-se um gabarito de $0,5 \times 0,5 \mathrm{~m}$. Fez-se a secagem do material em estufa de ventilação forçada, na temperatura de $65^{\circ} \mathrm{C}$ por 24 horas e calculou-se a média das amostras de matéria seca da parte aérea das plantas, em toneladas por hectare.

A cobertura do solo foi determinada pelo método da trena graduada, (Laflen et al. 1981), que consiste de uma corda ou trena de $15 \mathrm{~m}$ de comprimento subdividida em 100 pontos espaçados em $15 \mathrm{~cm}$. Esticou-se a trena em dez locais diferentes, selecionados aleatoriamente, visando obter uma amostragem geral da área. $O$ 
resultado, em porcentagem direta, foi obtido contando-se em cada amostra o número de pontos demarcados na trena que coincidiram diretamente sobre algum tipo de cobertura vegetal no solo. Com as médias de cada amostra, calculou-se a média geral e o coeficiente de variação da cobertura do solo.

\subsubsection{Caracterização do campo experimental}

A densidade do solo foi determinada pelo método do anel volumétrico, EMBRAPA (1979), nas profundidades de 0-5, 5-10, 10-15 e 15-20 cm, em quatro locais, aleatoriamente. Da mesma forma coletou-se amostras de solo nas mesmas profundidades para análise da umidade gravimétrica.

Para a análise da compactação do solo, utilizou-se o penetrômetro de impacto, IAA/Planalsucar - Stolf (ponta cônica com ângulo de $30^{\circ}$ e $23,9 \mathrm{~mm}$ de comprimento e 12,8 mm de diâmetro), retirando-se quatro amostragens, aleatórias, por parcela. Foram realizados 0 , 2, 4, e 6 impactos consecutivos no penetrômetro, em cada local de amostragem, anotando-se a profundidade de penetração da haste, em centímetros.

Coletou-se amostras de solo em cinco pontos diferentes da área experimental na profundidade de $0-25 \mathrm{~cm}$ para determinação da sua granulometria.

A temperatura do solo a $10 \mathrm{~cm}$ de profundidade foi medida com termômetro de mercúrio, no dia da semeadura, em cinco locais escolhidos aleatoriamente na área experimental, .

A declividade do terreno foi determinada através de nível topográfico com precisão de $5 \mathrm{~mm}$, em três locais representativos da área experimental. 


\subsubsection{Caracterização dos tratamentos e delineamento experimental}

Os tratamentos foram estabelecidos em função dos fatores a serem estudados: tipos de discos dosadores; velocidade de trabalho e; da lubrificação das sementes (Tabela 9).

Tabela 9. Fatores empregados nos tratamentos e seus respectivos níveis, para o estudo da distribuição longitudinal das plantas de milho na fileira.

\begin{tabular}{cccc}
\hline Tratamentos & $\begin{array}{c}\text { Velocidades de } \\
\text { trabalho }\left(\mathbf{m . s}^{-1}\right)\end{array}$ & $\begin{array}{c}\text { Tipo de discos } \\
\text { dosadores }\end{array}$ & $\begin{array}{c}\text { Lubrificação das } \\
\text { sementes }\end{array}$ \\
\hline 1 & 1,4 & Ferro & Sem \\
2 & 2,1 & Ferro & Sem \\
3 & 1,4 & Plástico & Sem \\
4 & 2,1 & Plástico & Sem \\
5 & 1,4 & Ferro & Com \\
6 & 2,1 & Ferro & Com \\
7 & 1,4 & Plástico & Com \\
8 & 2,1 & Plástico & Com \\
9 & 1,4 & Vertical pneumático & Com \\
10 & 2,1 & Vertical pneumático & Com \\
\hline
\end{tabular}

A área experimental foi dividida em 40 parcelas de $120 \mathrm{~m}^{2}(30 \times 4 \mathrm{~m})$, com quatro repetições de $30 \mathrm{~m}$ de comprimento e $4 \mathrm{~m}$ de largura. Sendo a distribuição das mesmas na área experimental, determinadas por sorteio. Adotou-se como bordadura das parcelas os 10 metros iniciais, destinados à estabilização da velocidade do conjunto trator-semeadora, e os $5 \mathrm{~m}$ finais destinados à desaceleração do conjunto, resultando 
numa área útil de $60 \mathrm{~m}^{2}$ (15 x $\left.4 \mathrm{~m}\right)$, na qual foram realizadas as medidas dos espaços entre plantas e contagem do número de plantas na fileira. Nas cabeceiras das parcelas manteve-se uma área livre de 3 metros, para ser utilizada como carreador para manobras.

O delineamento experimental utilizado foi o inteiramente aleatorizado, com quatro repetições. As variáveis respostas foram submetidos a análise da variância e cálculo do valor de $\mathrm{F}$ a $5 \%$ de significância, e as médias de tratamentos comparados, pelo método de Duncan (Gomes, 1978). Os dados foram analisados através do programa estatístico SAS (1994).

O efeito dos fatores tipo de disco, velocidade e lubrificação das sementes, na distribuição longitudinal e população de plantas, germinação, vigor, e danos às sementes, foi avaliado através de análise fatorial $(3 \times 2 \times 2)$, onde o primeiro fator tipo de disco foi composto pelos níveis: disco vertical pneumático, disco perfurado de ferro e de plástico. O segundo fator, velocidade foi composto pelos níveis $1,4 \mathrm{e} 2,1 \mathrm{~m} \cdot \mathrm{s}^{-1}$. O terceiro fator foi composto pelos níveis com e sem lubrificação das sementes. A análise fatorial da lubrificação das sementes foi realizada somente entre tratamentos com os discos perfurados de ferro e plástico. Não fez parte dos objetivos do presente estudo a avaliação do efeito da lubrificação no disco vertical. A semeadora pneumática teve a finalidade principal de servir como referência para comparação dos resultados com a máquina de precisão tipo disco perfurado horizontal, por isso deu-se as condições ideais para o seu perfeito funcionamento, empregando-se somente sementes lubrificadas.

\subsubsection{Semeadura do milho}

As semeadoras foram reguladas para distribuírem seis sementes por metro linear, a $3 \mathrm{~cm}$ de profundidade, no espaçamento de $0,9 \mathrm{~m}$ entre fileiras, considerando-se os índices estabelecidos por Balastreire (1990), ou seja: germinação de $90 \%$, índice de sobrevivência de $90 \%$, pureza varietal $99 \%$, patinamento de $6 \%$ na roda 
compactadora (na semeadora de precisão tipo disco perfurado horizontal) e $1 \%$ de patinamento na (semeadora pneumática com disco vertical). Utilizou-se também $300 \mathrm{~kg}$ de fertilizante da fórmula 4-20-12, por hectare, para atender o projeto de Norma $\mathrm{n}^{\circ}$ 04:015.06-007 ABNT (1994), que recomenda a manutenção dos depósitos de sementes e adubo das máquinas na metade da sua capacidade volumétrica. A população final de plantas estimada em todos os tratamentos, foi de 50.000 plantas.ha $^{-1}$.

O número de sementes distribuído pela semeadora-adubadora, foi aferido antes da semeadura nas parcelas, em uma área com condições similares às do experimento.

A seqüência das repetições dos tratamentos foi estabelecida através de sorteio. Entretanto, para evitar que resíduos de grafite interferissem nos resultados dos tratamentos com sementes sem lubrificação, procedeu-se, primeiramente, a semeadura nos tratamentos que utilizaram sementes sem lubrificação.

Para a lubrificação das sementes, colocou-se em um balde plástico, momentos antes da semeadura, $20 \mathrm{~kg}$ de sementes de milho e $40 \mathrm{~g}$ de pó de grafite, misturando-os manualmente, buscando-se a melhor homogeneização.

A semeadura nas parcelas foi realizada no sentido Oeste a Leste, suspendendo-se a semeadora no final de cada parcela, e transitando pelos carreadores demarcados. Desta forma evitou-se a passagem do trator na área já semeada e nas parcelas que estavam por semear.

Sete dias após a semeadura, fez-se uma aplicação do inseticida Deltamethrin, na dosagem de 5,0 gramas de principio ativo por hectare, para controle de pragas esporádicas presentes na área ( gafanhotos, lagartas e formigas).

\subsubsection{Avaliação da eficiência da semeadura}

Aos 15 dias após a emergência das plântulas iniciou-se a contagem das distâncias entre plantas na fileira. Nos 15 metros úteis das fileiras de cada parcela 
selecionou-se, aleatoriamente, $6 \mathrm{~m}$ ininterruptos e mediu-se os espaços entre plantas, utilizando-se a trena métrica de $200 \mathrm{~cm}$, com fundo de escala de $1 \mathrm{~mm}$. Utilizou-se 24 metros por repetição, ou seja 96 metros por tratamento. Obteve-se um valor superior a 400 espaços medidos por tratamento, estando de acordo com o projeto de norma $\mathrm{n}^{\circ}$ 04:015.06-007 da ABNT (1994), com base na norma ISO 7256-1 (1984), que estabelece o número mínimo de espaços medidos por tratamentos em 250, nas avaliações de distribuição espacial de plantas.

Aos 10 dias após a primeira contagem, realizou-se a segunda contagem do número e espaços entre plantas, em $15 \%$ dos tratamentos, selecionados aleatoriamente. Este procedimento teve por objetivo verificar se houve alteração da população e distribuição longitudinal de plantas em relação à primeira contagem. Como foi constatada uma diferença não significativa na população total de plantas, utilizou-se somente os dados levantados na primeira contagem.

A eficiência de semeadura foi avaliado com base nos seguintes atributos:

- População de plantas estabelecidas por hectare aos 15 dias após a emergência das plântulas;

- Coeficiente de variação dos espaços medidos entre plantas estabelecidas 15 dias após a emergência das plântulas;

- Precisão, compreendendo o cálculo do coeficiente de variação somente entre os espáços eceitáveis;

- Porcentagens de espaços aceitáveis, correspondentes a medida de 12 a $33 \mathrm{~cm}$ entre plantas;

- Porcentagem de espaços múltiplos, correspondentes aos espaços inferiores a $12 \mathrm{~cm}$ entre plantas;

- Porcentagem de espaços denominados de falhas, correspondentes aos espaços superiores a $33 \mathrm{~cm}$ entre plantas. 
Para o cálculo do coeficiente de variação foram considerados todos os tipos de espaçamentos da amostragem (múltiplos, falhas e aceitáveis), segundo o critério definido pelo DEA-IAC (Divisão de Engenharia Agrícola-Instituto Agronômico de Campinas) recomendado por Kurachi et al. (1989).

Os resultados obtidos do número de plantas por repetição, foram multiplicados pelo fator 462,5 , para obtenção da população de plantas por hectare. Para isto fez-se a divisão da metragem em um hoctare (11100 metros lineares) pelos $24 \mathrm{~m}$ coletados em cada parcela. A análise estatística foi realizada após essa transformação da população de plantas por hectare.

A precisão foi calculada com base na variabilidade de plantas na fileira, determinada através do coeficiente de variação dos espaços normais (Kachman \& Shmit, 1995). Utilizou-se para o cálculo da precisão a seguinte equação:

$$
C=\frac{S_{2}}{X_{\text {ref }}} \times 100
$$

sendo

$$
S_{2}=\sqrt{\frac{\sum_{i=1}^{N}(X i-\bar{X})^{2}}{N-1}}
$$

$$
\begin{aligned}
\text { em que: } \mathrm{C}= & \text { Precisão (\%); } \\
\mathrm{S}_{2}= & \text { Desvio padrão dos espaços aceitáveis entre plantas (cm); } \\
\mathrm{X}_{\text {ref }}= & \text { Espaço teórico }(22,2 \mathrm{~cm}) ; \\
\mathrm{Xi}= & \text { Distância entre duas plantas na fileira, da população estudada } \\
& (\mathrm{cm}) ; \\
\mathrm{N}= & \text { Número de plantas da amostra da população em estudo; } \\
\bar{X}= & \text { Espaço médio entre as plantas consideradas aceitáveis }(\mathrm{cm}) ;
\end{aligned}
$$


Utilizou-se nos trabalhos de campo, bancada e laboratório, as sementes de milho (Zea mays L.), cultivar AS-138 da Empresa Agroeste S/A, Xanxerê SC. Híbrido triplo, ciclo precoce, porte médio, grão semi-dentado amarelo, produzidas na safra $1995 / 96$, com germinação mínima de $85 \%$ e pureza mínima de $99 \%$, tratadas pelo fornecedor, com fungicidas a base de Perymiphos methyl 50\%, 4ppm, Deltametrina 2,5 \% 1ppm e Captan 75\% 100 ppm.

A caracterização das sementes ocorreu por meio da realização do teste de uniformidade (classificação por peneira), determinando-se as sementes que se situam dentro das dimensões previstas, isto é, as retidas nas peneiras 20 e 21/64 avos de polegada. Estabeleceu-se para este teste um conjunto de peneiras $(24 / 64,23 / 64,22 / 64$, 21/64, 20/64, 19/64 avos de polegada e fundo). Após serem sobrepostas, colocou-se 100 gramas de sementes sobre a peneira 24 , fez-se movimentos oscilatórios do conjunto de peneiras durante um minuto. Após a retenção das sementes, nas respectivas peneiras, pesou-se o conteúdo retido de sementes inteiras em cada peneira, e fundo, utilizando-se a balança eletrônica BG-400, com fundo de escala $0,01 \mathrm{~g}$, e computou-se os pesos resultantes em porcentagem (Brasil, 1992). Foram realizadas quatro repetições de 100 gramas, calculando-se a média obtida para cada peneira. Com os valores obtidos determinou-se o porcentual de sementes retidas pela peneira indicada pelo fornecedor (20) e as que tenham, obrigatoriamente, passado pela de malha imediatamente superior (21).

Fez-se a análise da germinação das sementes no laboratório, utilizando-se sementes de milho com 5 dias após a mistura do pó de grafite. Cada amostra foi subdividida em oito sub-amostras de 50 sementes envoltas em papel germitest e colocadas no germinador, mantidas a temperatura em $25^{\circ} \mathrm{C}$ e umidade relativa próximo a 100\%, conforme Brasil (1992). A avaliação foi realizada contando-se as plântulas normais no $4^{\circ}$ e $7^{\circ}$ dia. Realizou-se a comparação entre as médias obtidas para a certificação de que o pó de grafite não altera as características fisiológicas das sementes de milho. 
Procedeu-se a mistura 0,5 g de grafite em pó, em 500 gramas de sementes de milho sem lubrificação, utilizando-se a balança eletrônica BG-400, com fundo de escala $0,01 \mathrm{~g}$ e recipiente de plástico com capacidade volumétrica de $1000 \mathrm{~cm}^{3}$. Realizou-se a mistura, revolvendo-se as sementes seguidas vezes, impedindo assim o acúmulo de pó no fundo do recipiente. Repetiu-se o procedimento para as dosagem de 1 g e 1,5 g em $500 \mathrm{~g}$ de sementes. Após a mistura, retirou-se as sementes do recipiente e fez-se a pesagem do resíduo do grafite que não aderiu às sementes. Procedeu-se o teste com três diferentes proporções de pó de grafite, para obtenção da concentração que fizesse a lubrificação adequada das sementes, com baixo nível de resíduo no reservatório.

Para verificação da influência do grafite no peso hectolítrico das sementes, mediu-se o peso volumétrico, abastecendo-se o depósito da balança hectolítrica, e procedendo-se a queda das sementes, na altura, tempo e volume dimensionado pela própria balança. Sendo a balança volumétrica com capacidade para de $1.000 \mathrm{~cm}^{3}$ e leitura direta dos resultados em peso hectolítrico, procedeu-se a queda das sementes até transbordar o recipiente cilíndrico da balança. Retirou-se o excedente com espátula de madeira na inclinação e movimentos da espátula conforme recomendação (Brasil, 1992). Fez-se três repetições para sementes sem lubrificação e três para sementes lubrificadas, obtendo-se as médias das amostras separadamente com apresentação dos resultados direto em peso hectolítrico.

Determinou-se o grau de umidade das sementes simultaneamente, de acordo com o procedimento descrito na regras para análise de sementes (Brasil, 1992) a $105 \pm 3^{\circ} \mathrm{C}, 24$ horas. $\mathrm{O}$ teor de água foi expresso com base no peso úmido das sementes.

\subsubsection{Coleta de sementes para análise de danos físicos e fisiológicos às sementes}

Para a coleta das sementes que passaram pelo mecanismo dosador da semeadora de precisão tipo disco perfurado horizontal, foram estabelecidas as rotações do disco dosador de 0,36 e 0,53 rotações por segundo, obtidas através do número de 
pulsos do sensor ótico e registradas no cronodômetro eletrônico, o qual registrou os pulsos o com a precisão de 60 pulsos por giro do pinhão e o tempo em décimos de segundo. Essas rotações correspondem, respectivamente, às velocidades de trabalho da máquina no campo, de 1,4 e $2,1 \mathrm{~m} \cdot \mathrm{s}^{-1}$.

Atingida a rotação desejada, procedeu-se o funcionamento do mecanismo por dois minutos, para aferição do sistema de ejeção de sementes e oscilação da rotação do motor elétrico. Antes da coleta das amostras aguardou-se 15 segundos, conforme recomendação do Projeto de Norma no 04:015.04-004 (ABNT, 1994), aferidos com cronômetro digital com precisão de 0,1 décimo de segundo. Colocou-se uma embalagem de plástico na saída do tubo condutor das sementes, e fez-se a coleta de aproximadamente 1.000 sementes. Foram realizadas quatro avaliações por tratamento, sem interromper o giro do disco dosador, sendo coletados aproximadamente 4.000 sementes. Utilizou-se duas unidades da semeadora de precisão tipo disco perfurado horizontal com seus respectivos mecanismos dosadores, visando não misturar o resíduo de grafite nas sementes sem lubrificação.

Para obtenção de sementes na semeadora pneumática, a coleta foi realizada no campo, deslocando-se a máquina na área experimental. Fixou-se embalagens plásticas na saída dos tubos condutores e deslocou-se a máquina por 170 metros, na velocidade de $1,4 \mathrm{~m} . \mathrm{s}^{-1}$, repetindo-se o mesmo procedimento para a velocidade de $2,1 \mathrm{~m} . \mathrm{s}^{-1}$. Foram coletadas, aproximadamente 1.000 sementes por linha da máquina, ou seja, 4.000 unidades por tratamento. A velocidade foi mantida constante, mantendo-se a rotação da TDP em 540 rotações por minuto.

Além das sementes que passaram pelos mecanismos dosadores das máquinas, analisou-se os danos mecânicos e fisiológicos das sementes que não passaram pelos mecanismos dosadores, sendo caracterizado como tratamento 11 (testemunha). As amostras da testemunha foram coletadas aleatoriamente das embalagens procedentes do fornecedor, no volume e quantidade similar aos demais tratamentos, de aproximadamente 4.000 sementes. 


\subsubsection{Análises físicas e fisiológicas das sementes}

Para análise da germinação das sementes que passaram pelos mecanismos dosadores das semeadoras, separou-se oito sub-amostras de 50 sementes, por tratamento. Essas sementes foram distribuidas de forma simétrica em rolos de duas folhas de papel germitest e cobertas por uma terceira folha, sendo após enroladas (Figura 7). O papel foi umedecido com volume de água destilada equivalente a 2,5 vezes o seu peso. Os rolos, em posição vertical, foram colocados durante sete dias no germinador, mantida a temperatura de $25^{\circ} \mathrm{C}$, e umidade relativa do ar em tormo de 100 \%. A primeira e a segunda contagem das plântulas normais, foram realizadas no $4^{\circ}$ e no $7^{\circ}$ dia respectivamente (Brasil, 1992).

Da mesma forma, realizou-se um teste de germinação das sementes que não passaram pelo mecanismo dosador das máquinas, sendo considerado como testemunha.

Considerou-se germinada a semente que demostrou aptidão para produzir planta normal sob condições favoráveis de campo. Os resultados, expressos em porcentagem, foram obtidos da média aritmética das sub-amostras. Os critérios de avaliação basearam-se nas Regras para Análise de Sementes (Brasil, 1992), sendo consideradas plântulas normais aquelas com as estruturas essenciais bem desenvolvidas, completas, proporcionais e sadias. Foram consideradas plantas sadias, as que possuíam sistema radicular longo e bem desenvolvido, raiz primária longa e delgada, geralmente revestida por numerosos pêlos absorventes e terminando numa extremidade afilada. Plantas normais, quanto a parte aérea, eram compostas pelo coleóptilo com formato reto e bem desenvolvido, com uma folha verde a (plúmula), que se estende no seu interior até o ápice ou, eventualmente, emergindo através dele. 


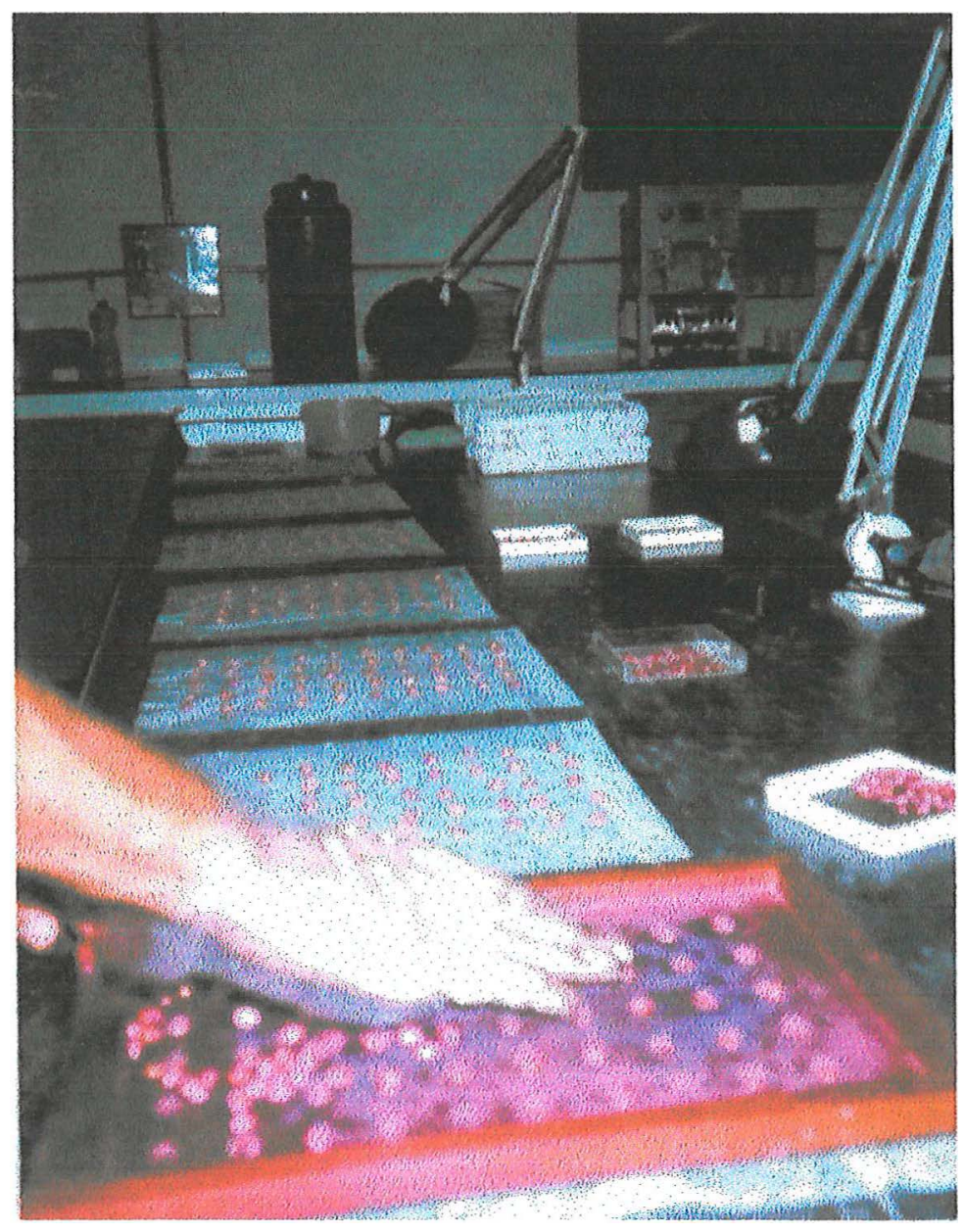

Figura 7. Preparo das amostras para avaliação da germinação e vigor das sementes

Para determinação do vigor das sementes, coletou-se de maneira aleatória quatro amostras por tratamento, cada uma com quantidade suficiente para preencher a tela do "ger-box". Colocou-se os "ger-box" com $40 \mathrm{ml}$ de água no fundo, na estufa incubadora durante 96 horas, mantida a temperatura de $42^{\circ} \mathrm{C}$ e umidade relativa de 90 a 95\% conforme Marcos Filho ( 1985). Após, as sementes foram submetidas ao teste de germinação, fazendo-se uma única contagem das plântulas normais 4 dias após a instalação.

Para determinação dos danos vısuaıs utilizou-se amostras com 50 sementes por repetição, ou seja, 200 por tratamento. A análise foi individual e realizada 
em laboratório. Procurou-se identificar em cada semente a existência de injúria que caracterizasse danos mecânicos nas partes constituinte das sementes (pericarpo, endosperma e embrião). Foram computados danos, independentemente se a ocorrência foi nos mecanismos das semeadoras, ou nas unidades de benificiamento da empresa produtora. Fez-se uma separação de grãos inteiros e os com danos visuais e calculou-se a porcentagem de sementes danificadas em relação ao total da amostra. Para definir se o dano na semente devia-se ao mecanismo da máquina, ou simplesmente fora uma lesão provocada por insetos, utilizou-se uma lupa, com capacidade de ampliação de seis vezes o tamanho normal.

\subsubsection{A valiação do enchimento de celas dos discos dosadores}

Para análise do efeito da velocidade dos discos perfurados de ferro e de plástico no enchimento das celas, foi estabelecido o tempo 20 segundos para os procedimentos de coleta e contagem de sementes, registrados no cronômetro digital com precisão de 0,1 centésimo de segundo. Visando facilitar a contagem das sementes, utilizou-se uma tábua de $40 \times 30 \mathrm{~cm}$, com 100 furos de $6 \mathrm{~mm}$ de profundidade e $12 \mathrm{~mm}$ de diâmetro. Os furos, distribuídos de forma simétrica, foram confeccionados para que apenas uma semente se alojasse em cada orifício.

Estabelecido o método de coleta das sementes, o disco dosador foi regulado em uma baixa rotação, aguardando-se 15 segundos para normalização do sistema e iniciando-se a coleta de sementes no tempo de 20 segundos. Procedeu-se a coleta e contagem das mesmas de forma semelhante, em 10 rotações progressivas. Variou-se, além da velocidade, o tipo de disco e a lubrificação das sementes. A avaliação do comportamento do sistema foi realizado graficamente, comparando-se os resultados calculados e os obtidos, para todas as situações estudadas. 


\section{RESULTADOS E DISCUSSÃO}

\subsection{Matéria seca e cobertura de palha no solo}

O valor médio da matéria seca sobre o solo, no momento da semeadura, foi de 3,6 tha ${ }^{-1}$, com o coeficiente de variação de 13,00. O índice de cobertura de solo com palha, calculado com a trena métrica, foi de $85 \%$, e o coeficiente de variação de 7,9 $\%$. Ambos coeficientes de variação podem ser considerados baixos, refletindo uma boa uniformidade de distribuição da cobertura de palha no solo.

\subsection{Atributos físicos e estruturais do solo}

Os atributos umidade e densidade do solo, no período que antecedeu a semeadura do milho, são mostradas na tabela 10.

Tabela 10. Umidade e densidade do solo até a profundidade de $20 \mathrm{~cm}$.

\begin{tabular}{|c|c|c|}
\hline $\begin{array}{c}\text { Profundidade } \\
\text { (cm) }\end{array}$ & $\begin{array}{c}\text { Umidade gravimétrica } \\
\left(\mathrm{g.g}^{-1}\right)\end{array}$ & $\begin{array}{c}\text { Densidade do solo } \\
\left(\mathrm{g} . \mathrm{cm}^{-1}\right)\end{array}$ \\
\hline 0 - 5 & $\mathbf{0 , 2 3 0}$ & 1,25 \\
\hline $5-10$ & 0,243 & 1,26 \\
\hline $10-15$ & 0,255 & 1,41 \\
\hline $15-20$ & 0,258 & 1,45 \\
\hline
\end{tabular}

A umidade gravimétrica do solo, no momento da semeadura, estava ao redor de $70 \%$ da capacidade de campo, garantindo o suprimento de água para a 
germinação das sementes. O coeficiente de variação para o atributo umidade do solo, foi de $8,18 \%$, indicando a presença de umidade em todo o perfil do solo avaliado, como pode-se observar na Tabela 10.

Nos aspectos referentes à compactação do solo, os resultados da densidade do solo indicaram níveis de compactação mais elevados nas camadas abaixo de $10 \mathrm{~cm}$, como pode-se observar na Tabela 10. A mesma tendência pode ser observada pelos dados do penetrômetro de impacto (Figura 8).

Os estudos da densidade, resistência à penetração e umidade, indicaram que no perfil do solo até a profundidade de $10 \mathrm{~cm}$, o solo apresentou as condições necessárias para implantação da cultura de milho. Considerando que a profundidade de semeadura foi realizada na profundidade de $3 \mathrm{~cm}$, os níveis de compactação nas camadas mais profundas não deve ter afetado a germinação das sementes.

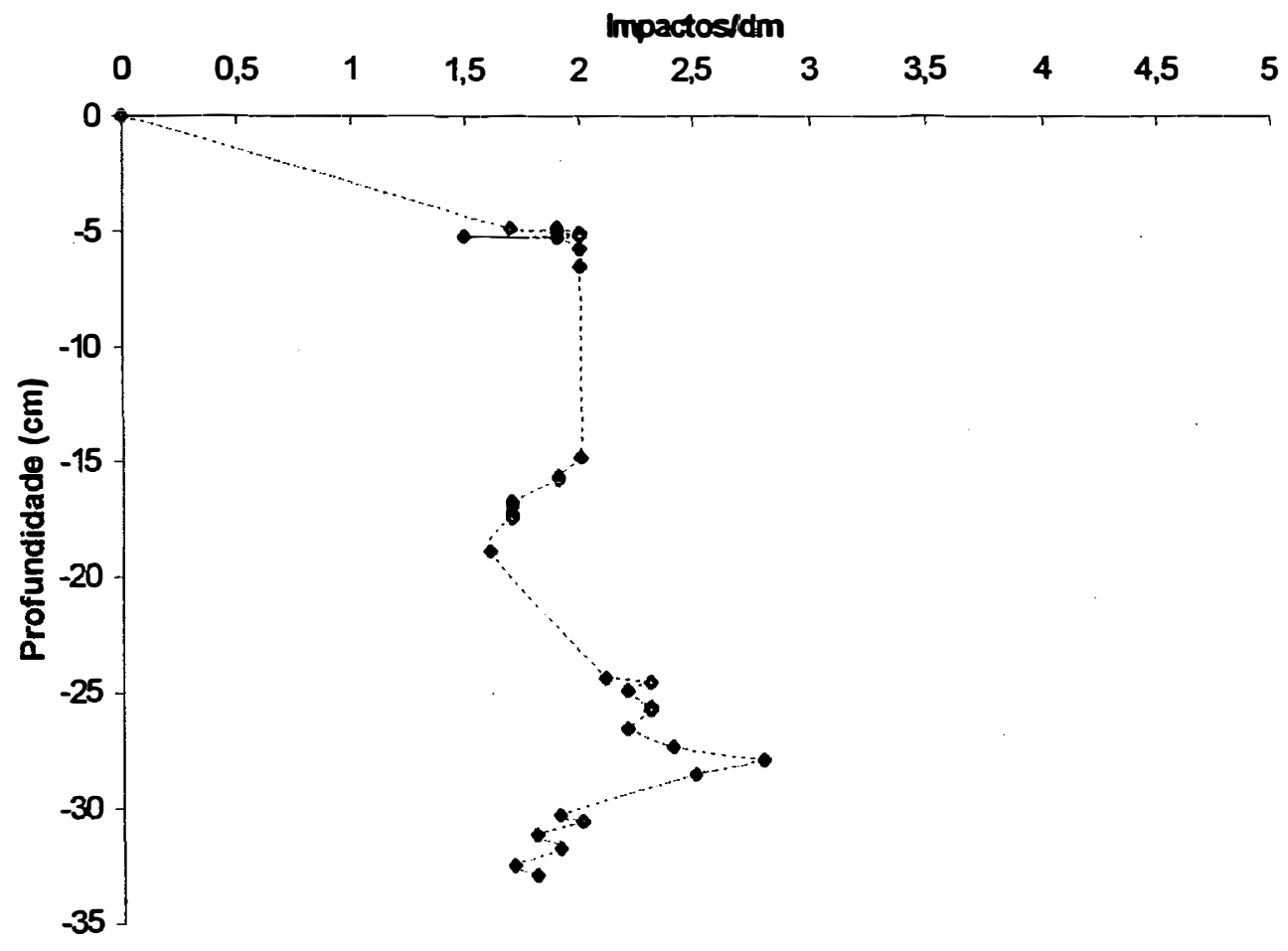

Figura 8 - Níveis de compactação do solo da área experimental. Média dos 10 tratamentos, obtida com penetrômetro de impacto. 


\subsection{Características físicas e fisiológicas das sementes}

$\mathrm{Na}$ Figura 9 estão apresentados os valores da retenção de sementes nas peneiras de 24/64 a 19/64 avos de polegada e fundo. Os valores obtidos com as peneiras 20 e 21/64 avos de polegada, correspondendo a 77,47 \% das sementes avaliadas. Segundo a Comissão Estadual de Sementes e Mudas de São Paulo - CESM/SP (1995/96), os valores obtidos deveriam ser 94\%. Depois destes percentuais obtidos com as peneiras 20 e 21 , a maior retenção de sementes ocorreu na peneira 22 , com $17,5 \%$. Considerando-se que as celas dos discos foram dimensionadas em função das sementes maiores, isto é $10 \%$ maior do que o diâmetros das maiores sementes (24/64 avos de polegada), entendeu-se que a captura de uma semente por cela não seria alterado. O mesmo não iria ocorrer se a retenção tivesse ocorrido nas peneiras menores, onde a possibilidade de captura de mais de uma semente por cela seria provável.

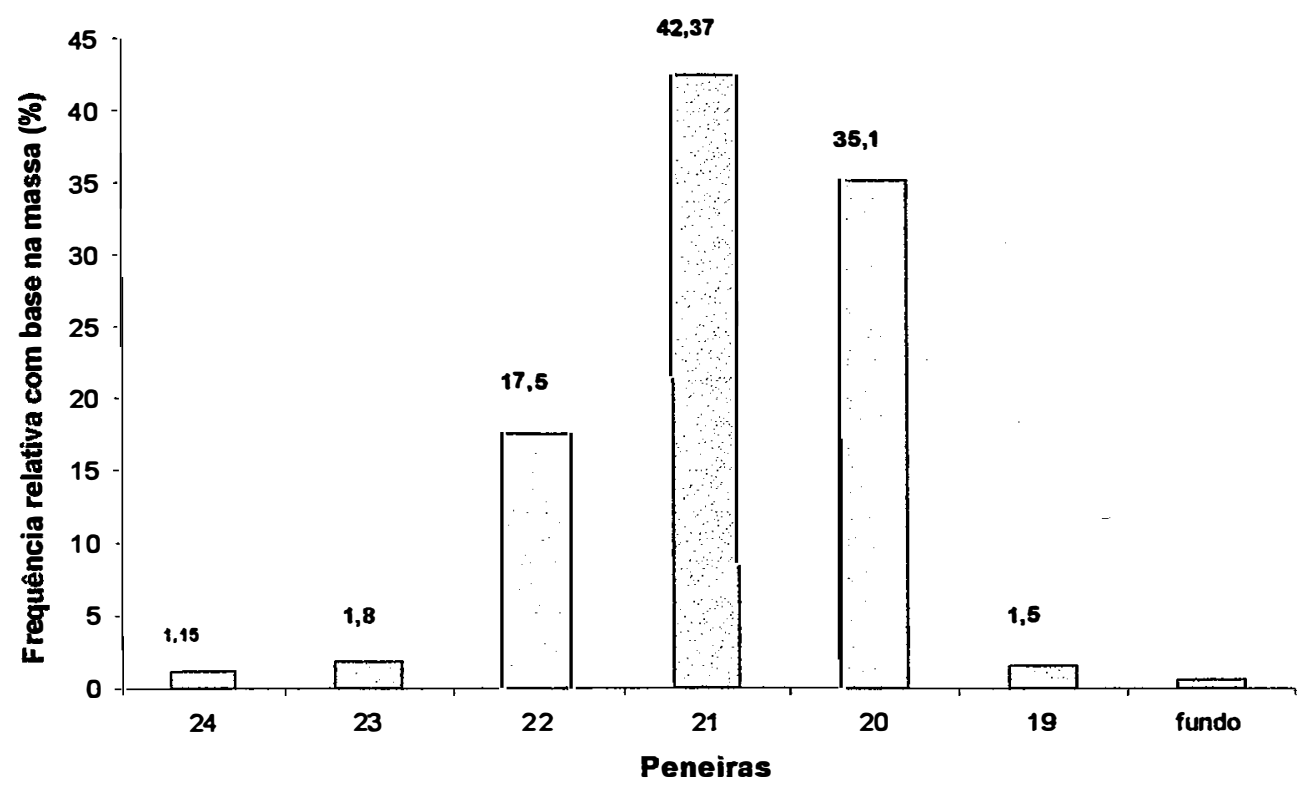

Figura 9. Classificação do milho, cultivar AS-138, pelo diâmetro das peneiras (24 a 19/64 avos de polegada e fundo). 
Os resultados da análise do resíduo de grafite, estão representados na Tabela 11 .

Tabela 11. Porcentagem resultante de resíduo de grafite na lubrificação de sementes de milho, nas dosagens de 0,5, 1,0 e 1,5 g de grafite por 500 gramas de milho.

\begin{tabular}{cccc}
\hline $\begin{array}{c}\text { Pó de grafite } \\
(\mathrm{g})\end{array}$ & Sementes de milho & Resíduo de grafite & Resíduo de grafite \\
\hline 0,5 & $(\mathrm{~g})$ & $(\mathrm{g})$ & $(\%)$ \\
1,0 & 500 & 0.012 & 2,40 \\
1,5 & 500 & 0.026 & 2,60 \\
\hline
\end{tabular}

Verificou-se, no laboratório, que a dosagem de $2 \mathrm{~g}$ de grafite por $1.000 \mathrm{~g}$ de milho, formou uma película que envolveu totalmente as sementes da amostra. Além disso, o nível de resíduo $(2,60 \%)$, foi baixo em relação à quantidade de grafite utilizado, caracterizando ser esta a proporção ideal para a lubrificação de sementes de milho, desde que ocorra a homogeneização da mistura.

$\mathrm{Na}$ análise do efeito do pó de grafite sobre a germinação das sementes, as médias obtidas foram 95,75\%, para as sementes com lubrificação $(\mathrm{CV}=1,75 \%)$ e $96,25 \%$ para as sementes sem lubrificação, $(C V=3,00)$. A pequena diferença entre as médias obtidas com sementes lubrificadas e sem lubrificação, indica que o pó de grafite não interferiu na germinação (Apêndice 6).

A Tabela 12 apresenta a diferença que ocorreu no peso hectolítrico, na comparação das sementes sem e com lubrificação.

A diferença de $2,6 \%$ dá indícios de um comportamento diferenciado de assentamento das sementes dentro de um reservatório, interferindo na captura das mesmas nas celas dos discos dosadores. 
Tabela 12. Peso hectolítrico das sementes de milho (média de três repetições).

\begin{tabular}{|c|c|c|}
\hline & 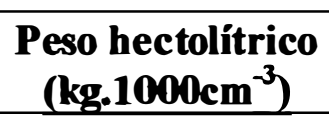 & $\begin{array}{c}\text { Umidade das sementes } \\
(\%)\end{array}$ \\
\hline Semente sem lubrificação & 72,61 & 11,1 \\
\hline Semente com lubrificação & 74,54 & 11,4 \\
\hline Diferenca (\%) & 2,6 & $\mathbf{0 , 3}$ \\
\hline
\end{tabular}

\subsection{Regularidade de distribuição longitudinal de plantas}

Os resultados dos experimentos de campo: coeficiente de variação (CV) dos espaços entre plantas, espaços aceitáveis, múltiplos, falhas e população de plantas por hectare são apresentados na Tabela 13. 


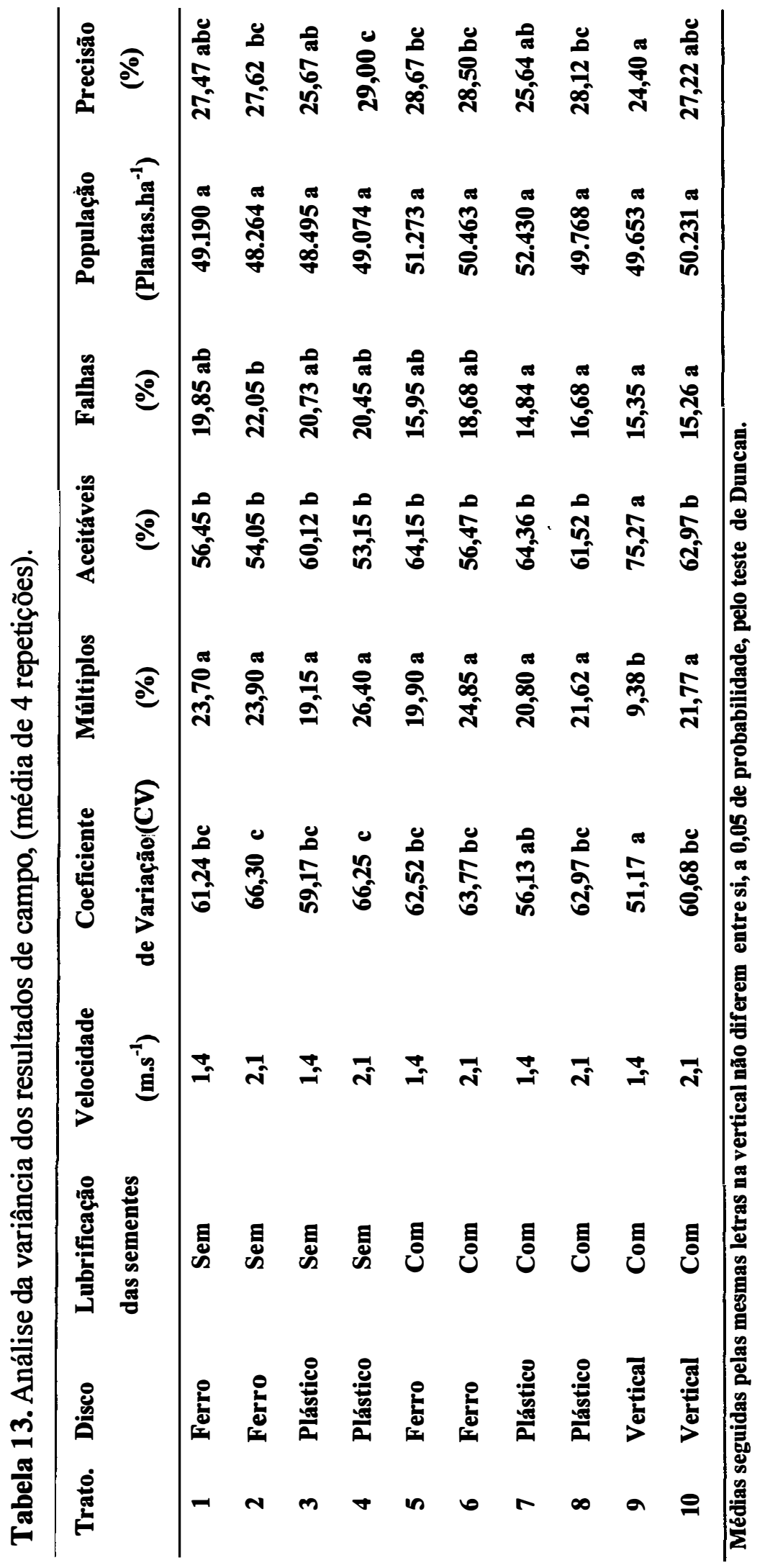


Os resultados da análise fatorial para avaliação do efeito do tipo de disco, velocidade e lubrificação das sementes na eficiência da semeadura, estão apresentados na Tabela 14. Devido às interações entre os fatores estudados não terem sido significativas, fez-se uma comparação das médias dos tratamentos, comparando-se os fatores entre si.

Tabela 14. Análise fatorial das médias obtidas no estudo dos fatores: tipo de disco dosador; velocidade de trabalho e; lubrificação das sementes.

\begin{tabular}{|c|c|c|c|c|}
\hline $\begin{array}{l}\text { Fatores } \\
\text { Estudados }\end{array}$ & $\begin{array}{l}\text { CV } \\
(\%)\end{array}$ & $\begin{array}{l}\text { Espaçamentos } \\
\text { Aceitáveis (\%) }\end{array}$ & $\begin{array}{c}\text { Múltiplos } \\
\text { (\%) }\end{array}$ & $\begin{array}{c}\text { Falhas } \\
(\%)\end{array}$ \\
\hline \multicolumn{5}{|l|}{ Tipo de disco } \\
\hline Vertical & $55,92 \mathrm{a} *$ & $69.13 \mathrm{a}$ & $15,56 \mathrm{a}$ & 15,3 a \\
\hline Plástico & $61,13 \mathrm{~b}$ & $60.00 \mathrm{~b}$ & $22,00 \mathrm{~b}$ & $18,15 a b$ \\
\hline Ferro & $63,43 \mathrm{~b}$ & $57.90 \mathrm{~b}$ & $23,07 \mathrm{~b}$ & $19,99 \mathrm{~b}$ \\
\hline \multicolumn{5}{|l|}{ Velocidade } \\
\hline $1,4 \mathrm{~m} \cdot \mathrm{s}^{-1}$ & $58,03 \mathrm{a}$ & $64.23 \mathrm{a}$ & $18,58 \mathrm{a}$ & $17,19 \mathrm{a}$ \\
\hline $2,1 \mathrm{~m} \cdot \mathrm{s}^{-1}$ & $63,99 \mathrm{~b}$ & $57.75 \mathrm{~b}$ & $23,70 \mathrm{~b}$ & $18,65 \mathrm{a}$ \\
\hline \multicolumn{5}{|l|}{ Semente } \\
\hline com Lubrificação & $61,35 \mathrm{a}$ & $64,06 \mathrm{a}$ & $21,78 \mathrm{a}$ & $16,25 \mathrm{a}$ \\
\hline sem Lubrificação & $63,21 \mathrm{a}$ & $59,21 \mathrm{~b}$ & $23,29 \mathrm{a}$ & 20,42 a \\
\hline
\end{tabular}

* Médias seguidas pelas mesmas letras na vertical não diferem entre si, a 0,05 de probabilidade, pelo teste de Duncan.

\subsubsection{Coeficiente de variação - CV}

Os resultados do coeficiente de variação obtido dos espaços medidos entre plantas na fileira de milho estão apresentados na Figura 10. 


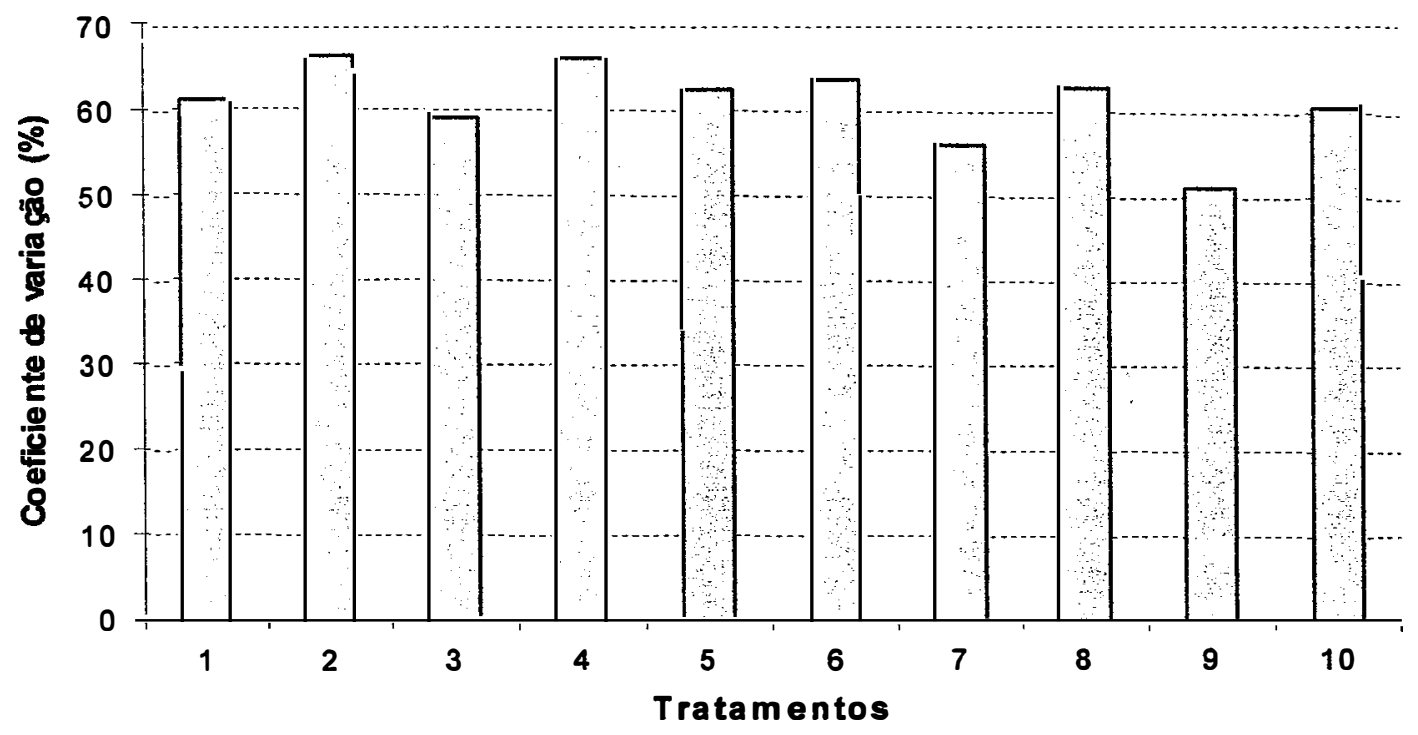

Figura 10. Coeficiente de variação obtido na distribuição longitudinal das plantas nos 10 tratamentos realizados, com as semeadoras de precisão tipo disco perfurado e pneumático.

A regularidade de distribuição longitudinal de plantas, na fileira, teve um comportamento diferenciado entre tratamentos, conforme resultados obtidos na análise da variância dos espaços medidos, como pode-se observar na Tabela 13. A semeadora pneumática, de disco vertical, na velocidade de trabalho de $1,4 \mathrm{~m} \cdot \mathrm{s}^{-1}$, apresentou o coeficiente de variação de $51,17 \%$, o menor valor em relação aos demais tratamentos.

O tratamento 7 (dosador tipo disco de plástico perfurado), com sementes lubrificadas, na velocidade de trabalho de $1,4 \mathrm{~m} \cdot \mathrm{s}^{-1}$, obteve um coeficiente de variação de $56,13 \%$, não diferenciando significativamente em relação ao valor obtido no tratamento 9 (semeadora de disco vertical) na velocidade de $1,4 \mathrm{~m} . \mathrm{s}^{-1}$, cujo $\mathrm{CV}$ foi de $51,17 \%$, entretanto diferenciando significativamente dos demais tratamentos. A maior diferença do CV foi $10 \%$, em relação ao tratamento 2 (dosador tipo disco de ferro perfurado), na velocidade de $2,1 \mathrm{~m} \cdot \mathrm{s}^{-1}$, com sementes sem lubrificação, cujo valor obtido foi de $66,30 \%$. 
Conforme apresentado na Tabela 14, a análise fatorial identificou efeito significativo, ao nível de 0,05 de probabilidade, para disco vertical nas médias obtidas dos tratamentos, com um coeficiente de variação de 55,92\%. Esse valor representa melhor resultado quando comparado com as médias obtidas nos tratamentos com disco de plástico e de ferro, cujos valores foram, respectivamente, $61,13 \%$ e $63,43 \%$. Não houve diferença significativa entre estes.

A análise estatística identificou efeito significativo do fator velocidade nos coeficientes de variação obtidos. Na velocidade da máquina de $1,4 \mathrm{~m} \cdot \mathrm{s}^{-1}$, o valor de CV foi $58,03 \%$, e na velocidade de $2,1 \mathrm{~m} . \mathrm{s}^{-1}$, foi de $63,99 \%$. A sensibilidade da semeadora, medido pelo $\mathrm{CV}$ dos espaçamentos entre plantas no campo ou sementes em bancada, tem sido observada por vários autores. Molin e Chang (1991), identificaram aumento do CV de $38,5 \%$ para $66,3 \%$, com acréscimo de velocidade de $0,55 \mathrm{~m} . \mathrm{s}^{-1}$ para 2,22 $\mathrm{m} \cdot \mathrm{s}^{-1}$. Kurachi et al. (1993), obtiveram resultados em que a velocidade foi um fator determinante na variação do $\mathrm{CV}$, quando compararam resultados de sete semeadoras. Observaram também que o disco vertical pneumático pressurizado obteve os valores mais baixos de $\mathrm{CV}$, os discos perfurados os valores mais altos, ficando em uma faixa intermediária os discos inclinados e dedos preensores (Tabela 3). Os coeficientes de variação obtidos no presente estudo, foram inferiores para o sistema pneumático em relação aos discos perfurados.

\subsubsection{Precisão (coeficiente de variação dos espaços aceitáveis)}

O coeficiente de varią̧ão obtido através dos espaços aceitáveis, não considerando portanto, os múltiplos e falhas, segundo Kachman \& Smith (1995), é o parâmetro mais indicado para determinar a efíciência da semeadura. Esse parâmetro é denominado de precisão, e os espaçamentos aceitáveis, foram os obtidos na faixa da distância de 12 a $33 \mathrm{~cm}$ entre plantas.

A análise da variância (Tabela 13) mostrou que existe uma interação significativa a 0,05 de probabilidade, indicando diferença entre os tratamentos. $O$ 
tratamento 9, com 24,4\% obteve o valor mais baixo em relação aos demais, indicando maior percentual de espaços próximos a distância de referência estabelecida de $22,2 \mathrm{~cm}$. Entretanto os valores obtidos dos tratamentos ficaram próximos de $29 \%$, o que indica que os espaços não se concentraram ao redor do valor de referência estabelecido, e sim distribuídos quase uniformemente dentro da faixa de 12 a $33 \mathrm{~cm}$. Molin et al. (1996), obtiveram valores da precisão entre $10,3 \%$ e $12,8 \%$, na velocidade de $2,0 \mathrm{~m} . \mathrm{s}^{-1}$, quando estudaram uma semeadora de milho em covas no sistema de semeadura direta.

\subsection{Espaçamentos aceitáveis}

A análise de variância para espaçamentos aceitáveis mostrou que existe uma interação significativa a 0,05 de probabilidade, indicando que os fatores apresentaram comportamento diferenciado com a variação da velocidade de trabalho, da lubrificação das sementes e do tipo de disco dosador utilizado. O tratamento 9 (disco vertical) com sementes lubrificadas e trabalhando na velocidade de $1,4 \mathrm{~m} . \mathrm{s}^{-1}$, diferenciou dos demais tratamentos, com 75,27 \% de espaços aceitáveis, como pode-se observar na Tabela 13.

Coelho (1997), sugere que a semeadora pneumática com disco vertical, na condição de estudo em bancada, obtenha no mínimo $90 \%$ dos espaços na faixa dos aceitáveis, e a semeadora com dosador tipo disco perfurado horizontal, $60 \%$. Tourino \& Klingsteiner (1983), para condição de estudo na bancada, consideram ótimo o desempenho da semeadora que distribuir de 90 a $100 \%$ das sementes na faixa de espaçamentos aceitáveis; bom desempenho, de 75 a $90 \%$ de espaçamentos aceitáveis; regular, de 50 a $75 \%$, e insatisfatório abaixo de 50

A comparação dos resultados entre os tratamentos para espaços aceitáveis, múltiplos e fal has, pode ser visualizada na Figura 11. 


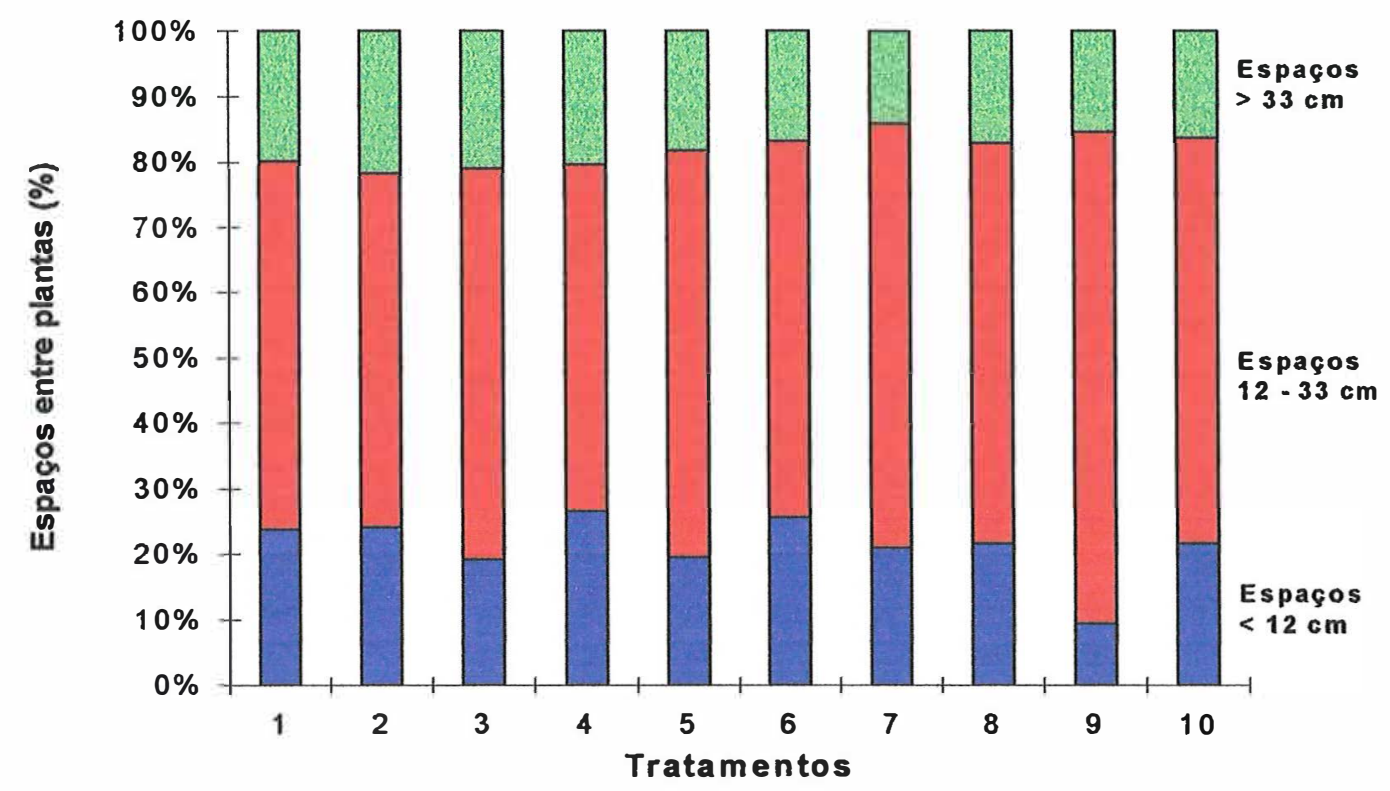

Figura 11. Percentual de espaços múltiplos, aceitáveis e falhas entre plantas de milho, resultante da semeadura com as máquinas estudadas.

Kurachi et al. (1993), em ensaio de bancada, obtiveram valores percentuais de espaçamentos aceitáveis entre sementes de milho, mais elevados em relação aos obtidos neste trabalho, ao estudar semeadoras de precisão tipo disco vertical pneumática, e inferiores nos testes com semeadoras de disco perfurados horizontais.

A análise de comparação múltipla das médias dos tratamentos, identificou efeito do tipo de disco dosador no índice de espaçamentos aceitáveis. A média obtida de aceitáveis foi de $69,13 \%$, para o dosador tipo disco vertical pneumático, 60,0 \% para o dosador tipo disco perfurado de plástico, e 57,9 \%, para o disco de ferro. Houve, portanto, diferença significativa para o disco vertical em relação aos discos de plástico e de ferro, que não apresentaram diferença entre si. A percentagem de espaçamentos aceitáveis foi em torno de $10 \%$ maior para o sistema pneumático em relação aos discos perfurados. Coelho (1997), sugere a diferença mínima de 30\%, para testes sobre bancada. 
$\mathrm{Na}$ análise do efeito da lubrificação das sementes sobre os espaçamentos aceitáveis, detectou-se diferença significativa ao nivel de 0,05 de probabilidade, quando se comparou as médias obtidas na análise dos mecanismos dosadores tipo disco perfurado horizontal. Quando se utilizou sementes com lubrificação, o indice foi de $64,06 \%$, e sem lubrificação, de 59,21\%.

A lubrificação alterou as características das sementes, variando o peso hectolítrico, conforme resultados obtidos no laboratório e apresentados na Tabela 12. Alterou também a fluidez das sementes, influenciando na porcentagem de espaçamentos aceitáveis, conforme pode-se observar na Tabela 13. A lubrificação das sementes é uma prática simples e econômica, que não altera as características fisiológicas das sementes, conforme os resultados obtidos no laboratório (Apêndice 6), viabilizando-se o seu uso sem haver inconvenientes.

O fator velocidade também influenciou na porcentagem de espaçamentos aceitáveis, diminuindo de $64,23 \%$ para $57,75 \%$ quando a máquina passou de 1,4 para 2,1 m.s. $\mathrm{s}^{-1}$. Para dosadores de sementes tipo disco perfurado horizontal, Delafosse (1986) recomenda valores máximos da velocidade periférica dos discos dosadores perfurados horizontal, segundo a FAO de $0,290 \mathrm{~m} \cdot \mathrm{s}^{-1}$, e ASAE de $0,315 \mathrm{~m} \cdot \mathrm{s}^{-1}$. As velocidades periféricas dos discos dosadores no momento da semeadura de milho, foram de 0,220 e 0,295 m.s $\mathrm{s}^{-1}$, correspondendo as velocidade de avanço de 1,4 e 2,1 $\mathrm{m} . \mathrm{s}^{-1}$, respectivamente. Verificou-se, portanto, que a velocidade periférica dos discos dosadores de $0,295 \mathrm{~m} . \mathrm{s}^{-1}$, é elevada segundo critérios da $\mathrm{FAO}$, podendo ser uma das causas do decréscimo ocorrido na porcentagem dos espaçamentos aceitáveis obtidos no trabalho.

A possibilidade de diminuir a velocidade periférica dos discos dosadores sem diminuir a velocidade de avanço da máquina, seria diminuindo o número de sementes por metro linear. Essa redução de sementes na fileira seria compensada com a redução da distância entre fileiras, mantendo assim a população de plantas esperada por hectare. Alternativas mecânicas seriam a duplicação do número de fileiras perfuradas no 
disco dosador ou o aumento do número de celas do disco dosador. Segundo Moreira et al. (1978), a precisão na distribuição de sementes é menos afetada por modificações no número de orifícios do disco do que pela sua velocidade.

A importância do arranjo de plantas para a cultura do milho se reflete no comportamento das plantas em relação à formação da espiga, esterilidade, acamamento e quebra de plantas e finalmente na produtividade, segundo vários autores. Rizardi et al. (1994), no entanto, concluíram que não houve diferença na produtividade de milho, independentemente dos espaçamentos utilizados entre fileiras $(0,7$ ou $0,9 \mathrm{~m})$, e que a cultura do milho foi capaz de compensar a desuniformidade de espaçamento entre plantas, mantida a mesma população de plantas por hectare.

Existe, portanto, certa divergência entre os autores, caracterizando a necessidade de se dar continuidade ao estudos, em diferentes arranjos de plantas para definir parâmetros na análise da eficiência de semeadura.

\subsection{Espaçamentos múltiplos entre plantas}

A análise de variância mostrou haver uma interação significativa ao nível de 0,05 de probabilidade para a porcentagem de espaçamentos múltiplos, como pode-se ver na Figura 11. O tratamento 9 (disco vertical pneumático, sementes lubrificadas e velocidade de trabalho de $\left.1,4 \mathrm{~m} \cdot \mathrm{s}^{-1}\right)$, apresentou o menor valor $(9,38 \%)$, e os demais tratamentos apresentaram porcentagem próximo a $20 \%$, conforme Tabela 13. A análise fatorial identificou efeito da velocidade na obtenção de espaços múltiplos, cujos valores obtidos foram de $18,58 \%$ a $1,4 \mathrm{~m} . \mathrm{s}^{-1}$ e de $23,70 \%$ a $2,1 \mathrm{~m} . \mathrm{s}^{-1}$, como pode-se observar na Tabela 14.

O fator disco teve efeito significativo sobre a porcentagem de múltiplos, cuja menor média foi de $15,56 \%$, obtida quando se utilizou disco vertical. Este valor é significativamente inferior aos do disco de plástico e de ferro, cujas médias foram $22,00 \%$ e 23,07\%, respectivamente e não se diferenciaram entre si. 
Os espaços múltiplos identificam um arranjo inadequado de plantas na fileira. Segundo Leite (1973) essa inadequação acarreta competição entre plantas por água, nutriente e luminosidade, resultando na deficiência de crescimento e formação de plantas, e com isso a queda na produtividade.

A lubrificação das sementes não teve efeito significativo sobre a porcentagem dos espaçamentos múltiplos.

\subsection{Espaçamentos falhos entre plantas}

Os espaçamentos considerados falhos, foram os que mediram acima de 1,5. $\mathbf{X}_{\text {ref. }}$ Como o espaçamento de referência foi estabelecido em $22,2 \mathrm{~cm}$, foram considerados espaçamentos falhos aqueles acima de $33 \mathrm{~cm}$. Houve diferença significativa entre tratamentos, como pode-se observar na Tabela 13, sendo que os tratamentos 9 e 7 obtiveram os menores valores de falhas, $(15,35 \%)$ e $(14,84 \%)$ respectivamente.

O tratamento 2 (dosador tipo disco perfurado de ferro, semente sem lubrificação a 2,1 m.s $\mathrm{s}^{-1}$ ), obteve a maior porcentagem de espaços falhas, (22,05\%). Os fatores que podem ter influenciado foram, a alta porcentagem de múltiplos ocorrido neste tratamento, ocasionando maiores espaços entre plantas.

\subsection{População de plantas}

As populações de plantas estão representadas na Figura 12, onde pode-se observar as diferenças ocorridas entre os tratamentos e também em relação à população esperada. 
A análise de variância (Tabela 13) mostrou que não existe uma interação significativa ao nível de 0,05 de probabilidade para a população de plantas. No entanto, procedeu-se a interpretação dos dados obtidos, devido à importância que os resultados possuem para o estudo que foi desenvolvido. Levantamentos realizados pela EMPASC/ACARESC em 1983, citado por Molin et al. (1996), identificaram que a população de milho das propriedades agrícolas da região Oeste de Santa Catarina, no momento da colheita, situou-se entre 30 e 50 mil plantas.ha ${ }^{-1}$. Mantovani et al. (1992), obtiveram populações de plantas na faixa de 35 a 42 mil plantas.ha ${ }^{-1}$, em 8 das 9 semeadoras-adubadoras de precisão testadas, onde cada fabricante regulou e realizou a semeadura.

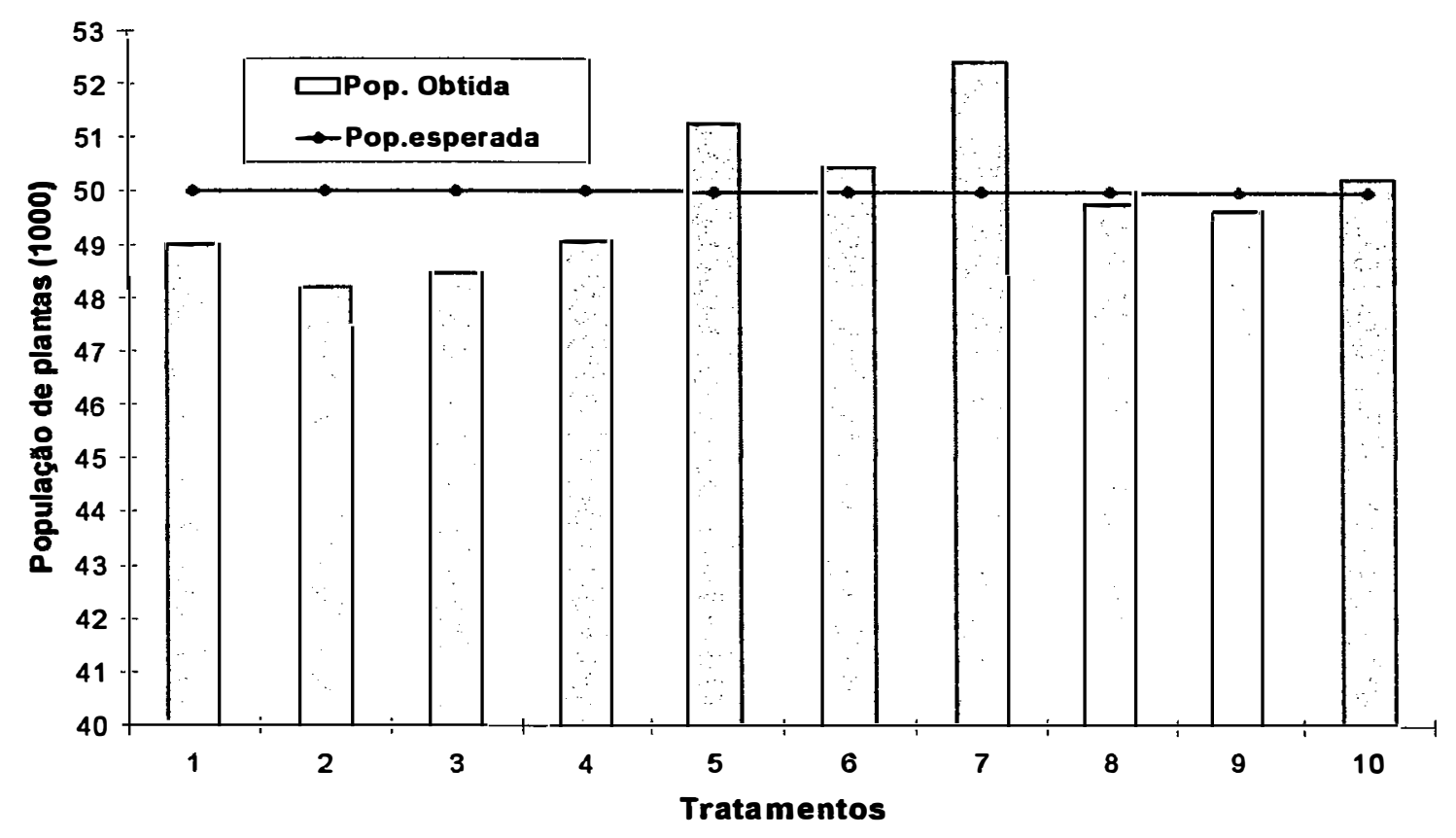

Figura 12. População de plantas obtidas e esperadas por hectare.

A população obtida com dosadores tipo disco perfurado, nos tratamentos realizados com sementes sem lubrificação, foi menor do que a obtida nos realizados com sementes lubrificadas. A lubrificação de sementes propiciou, portanto, maior fluidez às sementes, aumentando do número de plantas por hectare. Sementes 
lubrificadas tiveram um melhor assentamento nas celas dos discos perfurados e uma maior fluidez na passagem pelos orifícios do sistema injetor da semeadora.

Nas circunstâncias em que foram desenvolvidos os trabalhos, as

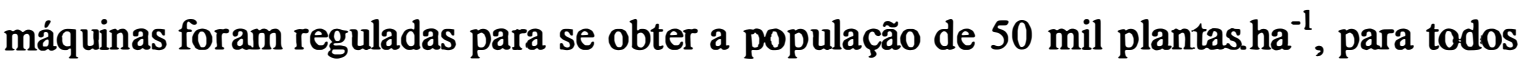
os tratamentos, atendendo a recomendação do fornecedor para a variedade de milho utilizada. $\mathrm{O}$ aumento do espaçamento entre plantas não proporciona a formação de mais espigas por plantas ou espigas maiores, porque o milho apresenta pouca plasticidade foliar e reprodutiva, não conseguindo compensar um baixo número de plantas por hectare (Russel, 1972).

A maior população de plantas ocorreu no tratamento 7 , com 52.430 plantas. ha ${ }^{-1}$ e a menor foi 48.264 plantas.ha $^{-1}$, no tratamento 2 (Apêndice 5). Considerando-se o índice de espiga por planta igual a 1,0 conforme Pozar e Zago (1990), e a massa média de uma espiga de milho segundo Nielsen (1995) de aproximadamente $0,13 \mathrm{~kg}$, a diferença encontrada de 4.166 plantas entre os tratamentos 2 e 7, indica a possibilidade de ocorrer diferenças de produção entre populações de plantas, devido às proporções existentes.

\subsection{Danos físicos às sementes}

Os resultados dos danos físicos causados às sementes são apresentados na Tabela 15 e Figura 13. A análise de variância para a média dos danos ocorridos às sementes, foi significativa ao nível de 0,05 de probabilidade, sendo o tratamento 2 (disco perfurado de ferro com sementes sem lubrificação e na velocidade de $2,1 \mathrm{~m} . \mathrm{s}^{-1}$ ), o que apresentou a maior incidência de danos (8,0\%). $O$ tratamento 1 (disco perfurado de ferro com sementes sem lubrificação, e trabalhando na velocidade de $\left.1,4 \mathrm{~m} \cdot \mathrm{s}^{-1}\right)$, com $7,25 \%$ de danos, apresentou também níveis superiores em relação, principalmente, aos tratamentos que utilizaram sementes lubrificadas. 
Tabela 15. Análise de variância dos resultados referentes aos danos provocados às sementes, à germinação e ao vigor.

\begin{tabular}{|c|c|c|c|c|c|c|}
\hline Tratamento & Disco & $\begin{array}{l}\text { Lubrificação } \\
\text { das sementes }\end{array}$ & $\begin{array}{c}\text { Velocidade } \\
\left(\mathrm{m}^{-\mathrm{s}^{-1}}\right)\end{array}$ & $\begin{array}{c}\text { Danos } \\
(\%) \\
\end{array}$ & $\begin{array}{c}\text { Germinação } \\
(\%) \\
\end{array}$ & $\begin{array}{c}\text { Vigor } \\
(\%)\end{array}$ \\
\hline $\mathbf{1}$ & Ferro & Sem & 1,4 & 7,25 ab * & 93,75 ab & 78,00 ab \\
\hline 2 & Ferro & Sem & 2,1 & 8,00 a & 92,25 b & 75,75 b \\
\hline 3 & Plástico & Sem & 1,4 & 6,50 abc & $95,00 \mathbf{a b}$ & 78,75 ab \\
\hline 4 & Plástico & Sem & 2,1 & $4,00 \quad c$ & 95,00 ab & $79,25 \mathrm{ab}$ \\
\hline 5 & Ferro & Com & 1,4 & 5,25 abc & 93,50 ab & $81,50 \mathrm{ab}$ \\
\hline 6 & Ferro & Com & 2,1 & 5,25 abc & 93,75 ab & $79,00 \mathrm{ab}$ \\
\hline 7 & Plástico & Com & 1,4 & 4,25 & 95,75 a & 82,25 a \\
\hline 8 & Plástico & Com & 2,1 & 4,50 bc & 93,25 ab & $82,00 \mathrm{ab}$ \\
\hline 9 & Vertical & Com & 1,4 & $4,25 \mathrm{C}$ & 94,75 ab & 82,00 ab \\
\hline 10 & Vertical & Com & 2,1 & 4,00 & 95,20 a & 81,00 ab \\
\hline 11(Test.) & - & Sem & - & 4,75 bc & $95,00 \mathbf{a b}$ & $81,75 \mathrm{ab}$ \\
\hline
\end{tabular}

* Médias seguidas pelas mesmas letras na vertical não diferem entre si, a 5\% de probabilidade, pelo teste de Duncan.

Conforme resultados apresentados na Tabela 16, referente à analise fatorial das médias obtidas nos tratamentos, observou-se que o tipo de disco dosador teve efeito sobre a percentagem de danos às sementes a nível de 0,05 de probabilidade, sendo a média dos tratamentos com disco de ferro 6,29\%, significativamente superior a média de $4,86 \%$ do disco de plástico, e $4,12 \%$ do disco vertical.

O fator velocidade não teve efeito significativo sobre a porcentagem de danos às sementes.

A análise fatorial detectou efeito significativo da lubrificação das sementes na redução dos danos, sendo a média das sementes sem lubrificação $6,44 \%$, e das sementes lubrificadas 4,81\% (Tabela 16). A causa provável da redução de danos foi o lubrificante, que aumentou a fluidez das sementes e reduziu o atrito das sementes com os órgãos ativos da máquina. 
Tabela 16. Análise fatorial das médias obtidas no estudo dos fatores: Tipo de disco dosador; velocidade e; lubrificação nos danos às sementes.

\begin{tabular}{lccc}
\hline $\begin{array}{l}\text { Fatores } \\
\text { Estudados }\end{array}$ & $\begin{array}{c}\text { Vigor } \\
(\%)\end{array}$ & $\begin{array}{c}\text { Germinação } \\
(\%)\end{array}$ & $\begin{array}{c}\text { Danos } \\
(\%)\end{array}$ \\
\hline Tipo de disco & & & \\
Vertical & $85,50 \mathrm{a}^{*}$ & $95,00 \mathrm{a}$ & $4,12 \mathrm{a}$ \\
Plástico & $80,53 \mathrm{a}$ & $94,75 \mathrm{ab}$ & $4,86 \mathrm{a}$ \\
Ferro & $78,56 \mathrm{a}$ & $93,31 \mathrm{~b}$ & $6,29 \mathrm{~b}$ \\
Velocidade & & & \\
$1,4 \mathrm{~m} . \mathrm{s}^{-1}$ & $80,50 \mathrm{a}$ & $94,55 \mathrm{a}$ & $5,50 \mathrm{a}$ \\
2,1 m.s ${ }^{-1}$ & $79,40 \mathrm{a}$ & $93,90 \mathrm{a}$ & $5,15 \mathrm{a}$ \\
Semente & & & \\
& & $94,06 \mathrm{a}$ & $4,81 \mathrm{a}$ \\
com Lubrificação & $81,41 \mathrm{a}$ & $94,0 \mathrm{a}$ & $6,44 \mathrm{~b}$ \\
sem Lubrificação & $77,75 \mathrm{~b}$ & & \\
\hline
\end{tabular}

* Médias seguidas pelas mesmas letras na vertical não diferem entre si, a 0,05 de probabilidade, pelo teste de Duncan.

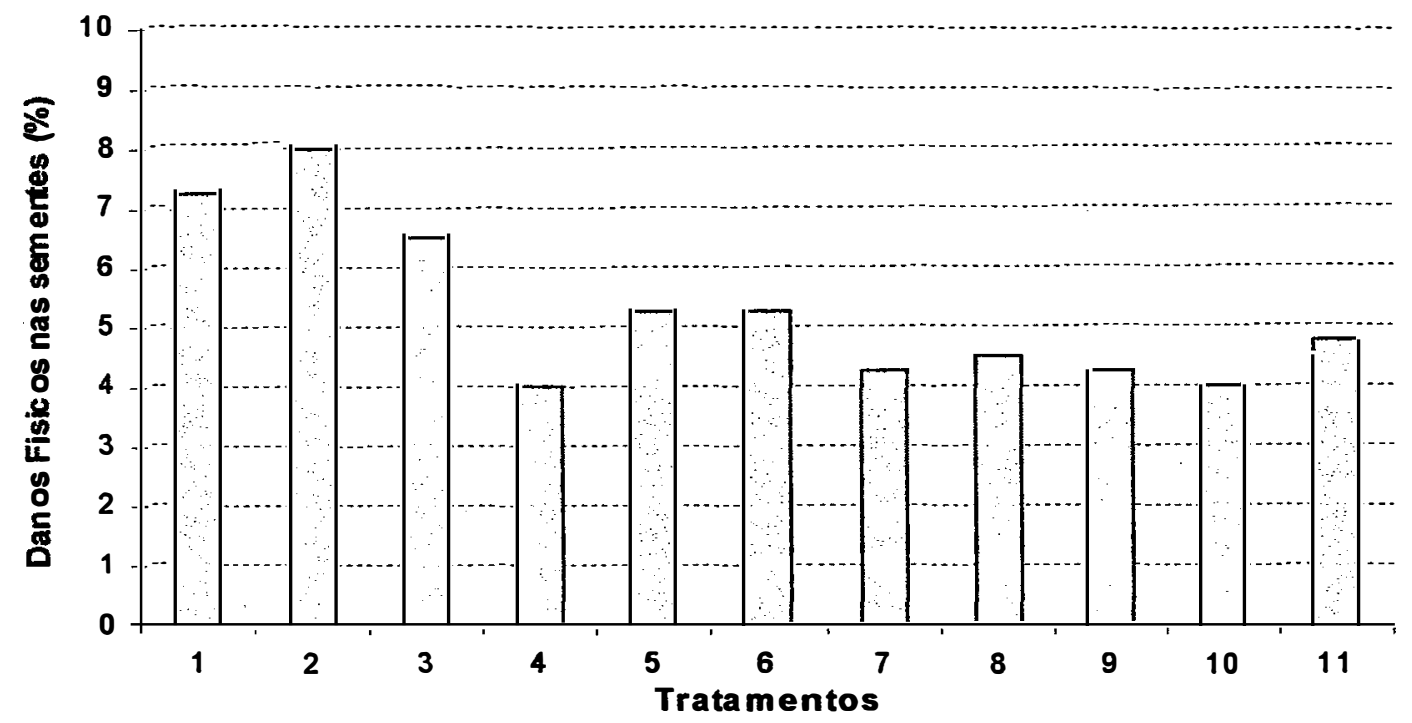

Figura 13. Percentagem de danos às sementes que passaram pelos mecanismos dosadores das semeadoras nos tratamentos realizados. 
A análise fatorial também detectou efeito significativo do fator tipo de disco dosador na redução de danos às sementes. Ocorreu 6,29 \% de danos nos tratamentos com disco de ferro, 4,87\% nos tratamentos com disco de plástico e 4,13\% no disco vertical. Boller et al. (1991) verificaram também, que o sistema dosador tipo disco de ferro perfurado proporcionou maior porcentagem de quebra em sementes de soja do que o dosador tipo disco perfurado de náilon.

\subsection{Porcentagem de germinação}

A porcentagem de germinação apresentou diferença significativa ao nível de 0,05 de probabilidade, para os tratamentos 7 e 9 , os quais obtiveram as médias mais altas $(95,75 \%$ e $95,20 \%)$ e significativamente superiores aos demais (Tabela 15$)$. A menor porcentagem obtida ocorreu no tratamento 2 (92,25\%). A Figura 14 também apresenta estes dados.

O único fator que apresentou efeito sobre a germinação foi o tipo de disco, conforme apresentado na Tabela 16. A média dos tratamentos com disco vertical foi $95,00 \%$ de germinação e dos tratamentos com discos de ferro, 93,31\% de germinação. Não houve diferença significativa entre disco vertical e disco de plástico, nem entre disco de plástico e disco de ferro.

A diferença de germinação das sementes que passaram pelo disco vertical e pelo disco de plástico não foi significativa. Isto se repete com o que ocorreu com danos às sementes, podendo ser uma consequência do mesmo. 


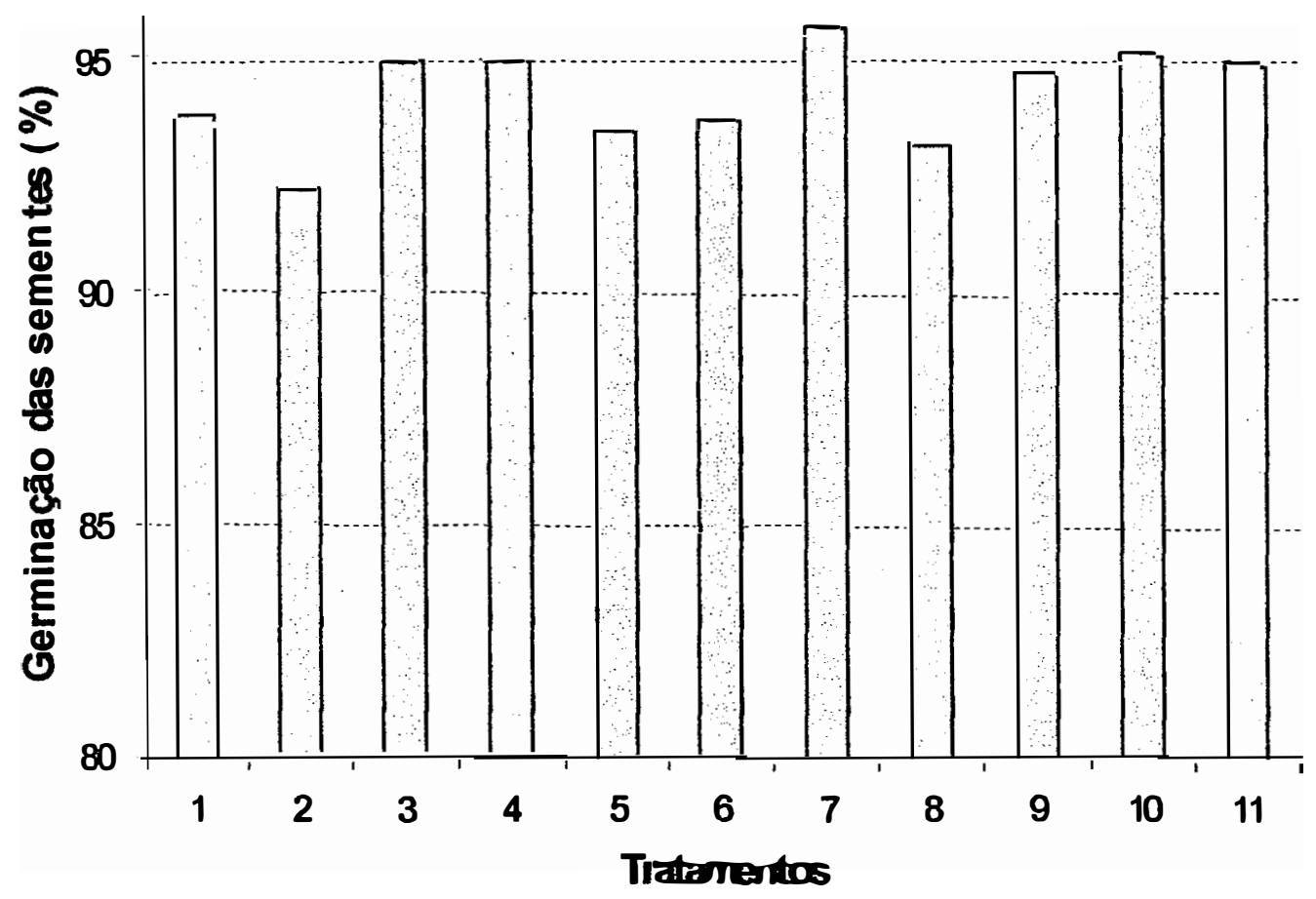

Figura 14. Germinação das sementes que passaram pelos mecanismos dosadores das semeadoras nos tratamentos realizados.

Monteiro (1989), afirma que a captura e ejeção das sementes no sistema que utiliza disco vertical pneurnático, reduz as possibilidades de impactos nas sementes por cisalhamento, reduzindo os efeitos denominados imediatos por Carvalho e Nakagawa (1980), os quais se fazem sentir logo após a semente ter sido injuriada, e caracterizam-se como graves apenas quando o grau de injúria é muito grande. Esse processamento mais brando do mecanismo dosador tipo disco vertical em relação ao dosador tipo disco perfurado de ferro, fez-se sentir na porcentagem de danos e na germinação das sementes. 


\subsection{Porcentagem de vigor}

Na Figura 15 são apresentadas as percentagens de vigor das sementes observadas nos 11 tratamentos.

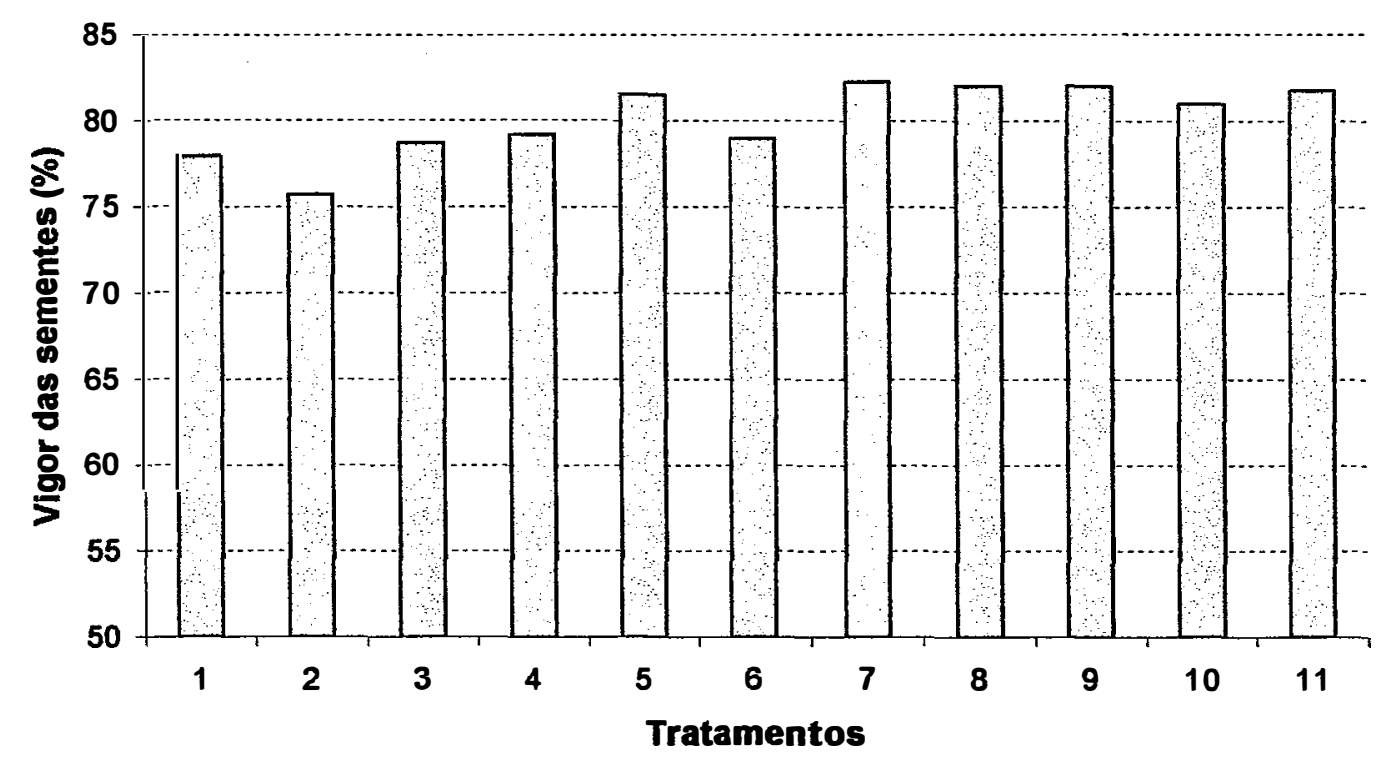

Figura 15. Vigor das sementes que passaram pelos mecanismos dosadores das semeadoras nos tratamentos realizados.

Pela análise da variância observou-se diferença significativa entre os tratamentos ao nível de 0,05 de probabilidade para a porcentagem de vigor (Tabela 15), sendo o tratamento 7, o que apresentou a melhor média, (82,25\%) e o tratamento 2, a menor (75,75\%). Os tratamentos 7 e 2 diferenciaram entre si, não se diferenciando, entretanto, dos demais.

Esta diferença de vigor encontrada entre os dois tratamentos pode ser decorrente dos danos mecânicos causado às sementes, cujas diferenças também foram significativas. $O$ vigor provavelmente influenciou na emergência de plantas, contribuindo para a redução da população de plantas por hectare nos tratamento 1 e 2 , conforme analisado anteriormente. 


\subsection{Enchimento das celas}

Os resultados de enchimento de celas obtidos no ensaio com discos dosadores perfurados horizontais estão apresentados na figura 16.

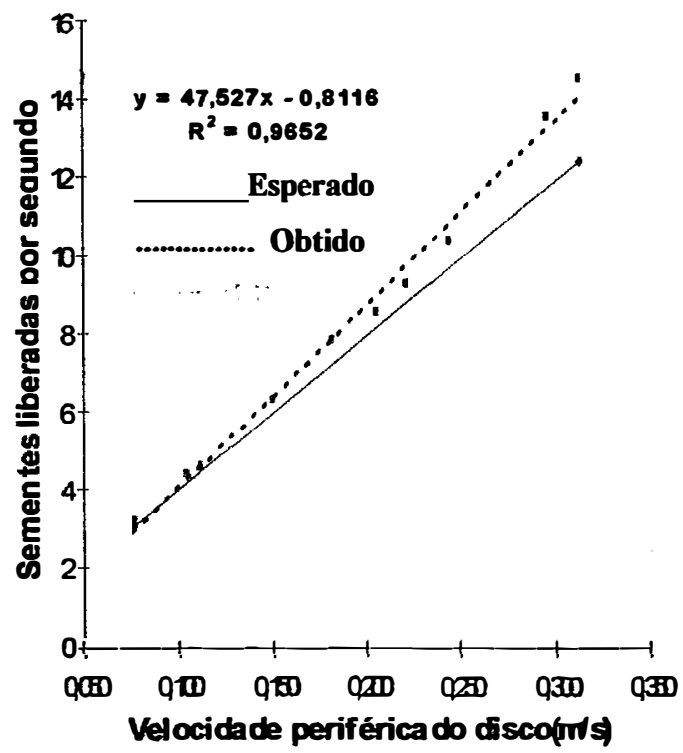

a) - Disco de ferro, semente sem lubrificação

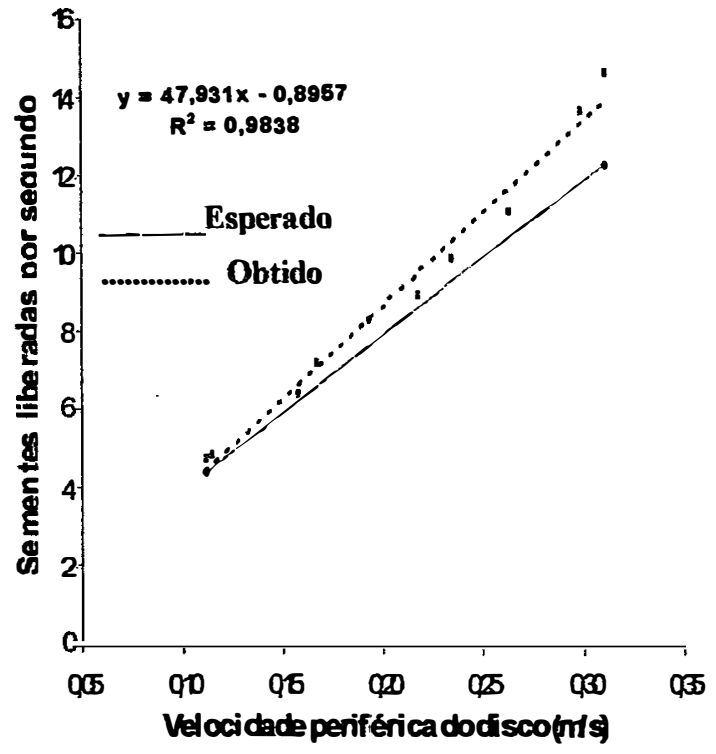

c) Disco de plástico, semente sem lubrificação

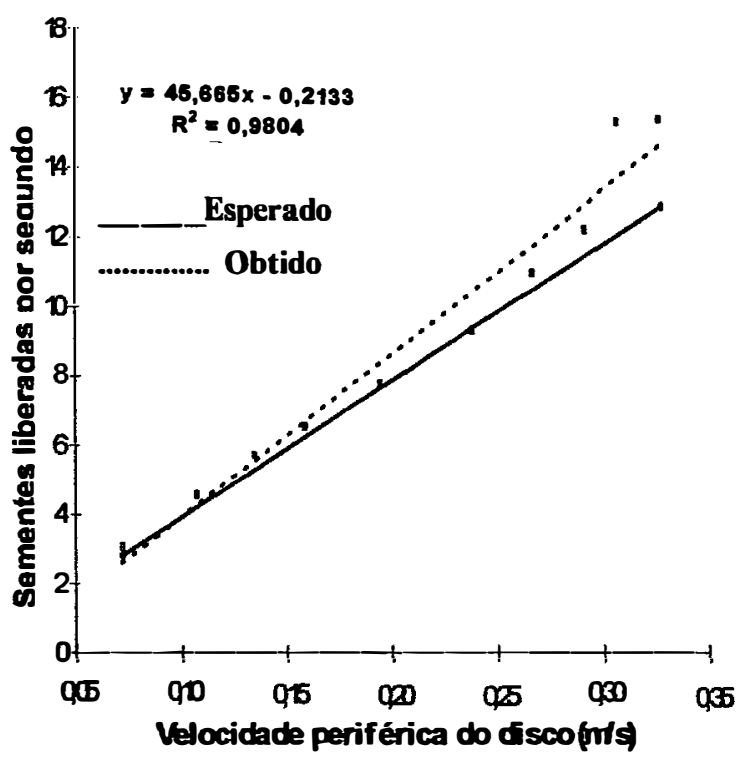

b) Disco de ferro, semente com lubrificação

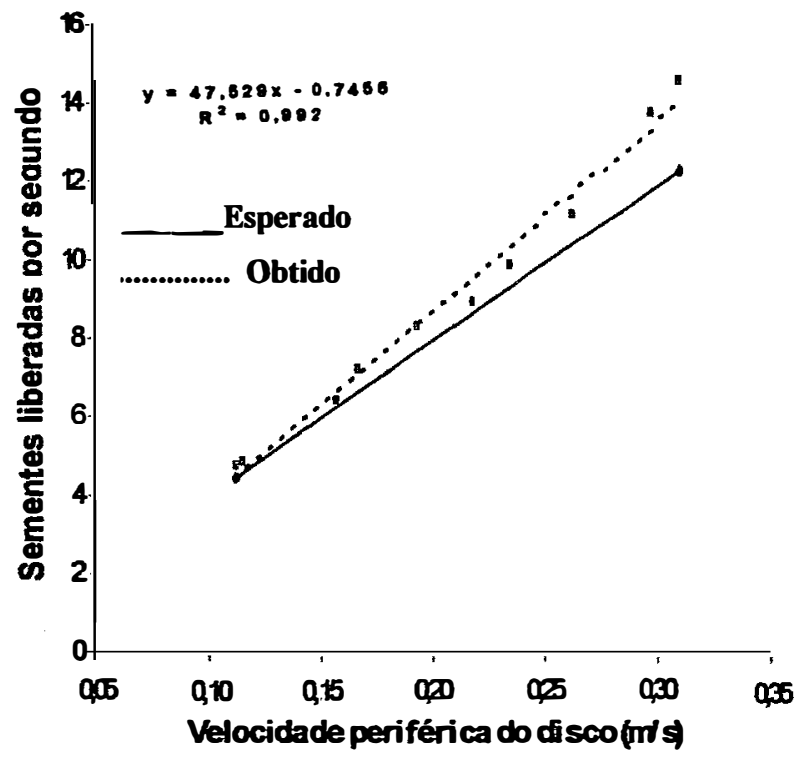

d) Disco de plástico, semente com lubrificação

Figura 16. Número de sementes liberadas por segundo com o aunento da velocidade periférica do disco dosador, em $\mathrm{m} . \mathrm{s}^{-1}$. 
A reta resultante dos volores obtidos identificou a tendência do aumento do percentual de enchimento à medida que a velocidade periférica dos discos dosadores aumentou. Em todos os tratamentos observou-se que o enchimento das celas foi acima de $100 \%$, caracterizando a ocorrência crescente do alojamento de mais do que uma semente por cela.

Com o aumento da velocidade, esperava-se uma redução do percentual de enchimento, pela maior dificuldade de captura de sementes na cela, em função do menor tempo de alojamento. Entretanto, ocorreu um aumento acentuado do porcentual de enchimento. Isso deveu-se, provavelmente pela captura de mais do que uma semente por cela, aliado ao fato do aumento da velocidade periférica do disco ter provocado uma sobrecarga no razador, comprimindo a mola e reduzindo assim o efeito do mesmo.

Os resultados sugerem que haja uma troca de informações maior entre fabricantes de máquinas e produtores de sementes, fundamentada nas dificuldades que o produtor tem em realizar a semeadura de diferentes culturas, diferentes formas e dimensões das sementes. Máquinas pneumáticas, possuem mecanismos eficazes para realizar a semeadura conforme as recomendações agronômicas. Porém, para a grande parcela de produtores que utilizam semeadoras de precisão tipo disco perfurado, a falta de mecanismos mais versáteis na dosagem de sementes, pode ser uma das causas da baixa eficiência de semeadura em muitas propriedades agrícolas. 


\section{CONCLUSÕES}

A análise dos resultados permitiram as seguintes conclusões:

- A semeadora pneumática de precisão com disco dosador vertical, na velocidade de avanço de $1,4 \mathrm{~m} . \mathrm{s}^{-1}$, apresentou a maior percentagem de espaços aceitáveis, menor coeficiente de variação e os danos às sementes foram baixos.

- Com a semeadora de precisão com disco perfurado de plástico, na velocidade de avanço de $1,4 \mathrm{~m} \cdot \mathrm{s}^{-1}$ e utilizando sementes lubrificadas, obteve-se valores de espaços aceitáveis, próximos aos obtidos com a semeadora pneumática e melhores se comparado com os demais.

- Com a semeadora de precisão com disco perfurado de plástico, na velocidade de avanço de $1,4 \mathrm{~m} \cdot \mathrm{s}^{-1}$, utilizando sementes lubrificadas, não houve diferença no coeficiente de variação em relação à semeadora pneumática de precisão com disco dosador vertical e os danos às sementes foram baixos.

- Houve tendência genérica da redução do percentual de espaços aceitáveis e aumento dos espaços falhos, quando a velocidade trabalho aumentou de 1,4 $\mathrm{m} . \mathrm{s}^{-1}$ para $2,1 \mathrm{~m} \cdot \mathrm{s}^{-1}$.

- Com a lubrificação das sementes, houve uma tendência do aumento do percentual dos espaços aceitáveis entre plantas e redução dos danos mecânicos às sementes, na avaliação dos resultados obtidos com mecanismos dosadores de discos perfurados horizontais. 
- O percentual de enchimento das celas apresentou tendência de aumento, com a variação progressiva da velocidade periférica dos discos perfurados horizontais.

- As semeadoras de precisão tipo disco perfurado horizontal, operando nas velocidades próximas a $1,4 \mathrm{~m} . \mathrm{s}^{-1}$, com sementes lubrificadas e dimensionamento correto das celas dos discos em relação às dimensões das sementes, podem realizar uma distribuição longitudinal de plantas que atenda aos padrões agronômicos. 


\section{REFERÊNCIAS BIBLIOGRÁFICAS}

ADEGAS, F. S. Manejo integrado de plantas daninhas. In: CONFERÊNCIA ANUAL DE SEMEADURA DIRETA, 2., Pato Branco, 1997. Anais. Passo Fundo: Aldeia Norte, 1997. p.17-33.

ASSOCIAÇÃO BRASILEIRA DE NORMAS TÉCNICAS. Semeadora - semeadora adubadora - máquina aplicadora de fertilizante e/ou corretivo em linha - ensaio de campo - método de ensaio: Projeto de norma 04:015.06-004: São Paulo, 1994. $25 \mathrm{p}$.

BALASTREIRE, L.G. Máquinas agrícolas. São Paulo: Manole, 1990. 310 p.

BERNACKI, H.; HAMAN, J.; KANAFOJSKI, C.Z. Seeding machines. In: Agricultural machines: theory and construction. Warsan: National Tecnical Information Service, 1972. v.1, cap 13. p. 619-737.

BOLLER, W.; GAZZOLA, O.; SAVERO, J.L. et al. Avaliação de efeitos de mecanismos dosadores de semeadoras sobre danos mecânicos e fisiológicos em sementes de soja. In: CONGRESSO BRASILEIRO DE ENGENHARIA AGRÍCOLA, 20., Londrina, 1991. Anais. Londrina: SBEA, 1991. v.2, p.11801194.

BRASIL. Ministério da Agricultura e Reforma Agrária. Regras para análise de sementes. Brasilia, 1992. 188 p. 
BUFTON, L. P.; RICHARDSON, P.; O'DONGHERTY, M. J. Seed displacement after impact an a soil surface. Journal of Agricultural Engineering Research, v.19, p.327-338, 1974.

BUTIERRES, E. Análise da uniformidade de espaçamento e danificação mecânica na distribuição de sementes de soja. (Glycine max (L.) Merril). Santa Maria, 1980. 70p. Dissertação (Mestrado) - Universidade Federal de Santa Maria.

CALEGARI, A. Culturas de cobertura para o semeadura direta em solos argilosos. In. CONFERÊNCIA ANUAL DE SEMEADURA DIRETA, 2., Pato Branco, 1997. Anais. Passo Fundo: Aldeia Norte, 1997. p. 51-61.

CARVALHO, N.M.; NAKAGAWA, J. Sementes: ciência, tecnologia e produção. 2. ed. Campinas: Fundação Cargil, 1980. 326 p.

CAVIGLIONE, J.H.; ARAÚJO, A.G. de.; CASÃO JUNIOR, R. et al. Definindo prioridades em mecanização agrícola para a região norte do Paraná. In: CONGRESSO BRASILEIRO DE ENGENHARIA AGRÍCOLA, 20., Londrina. 1991. Anais. Londrina: IAPAR/SBEA, 1991. v.2, p.950-983.

CESM/SP - Comissão Estadual de Sementes e Mudas de São Paulo. Padrões de sementes- grandes culturas. Secretaria da Agricultura e Abastecimento de São Paulo. 1995/1996.

COELHO, J.L.D. Ensaio \& certificação das máquinas para a semeadura. In: MIALHE, L.G. Máquinas agrícolas ensaios \& certificação. Piracicaba: Shekinah, 1997. cap.11, p.551-570.

DELAFOSSE, R.M. Máquinas sembradoras de grano gruesso. Santiago: INTA/FAO, 1986. $48 \mathrm{p}$.

DUNCAN, G.H.; LANG., A.L.; PENDLETON, J. W. Com plant population in relation to soil productivity. Advances in Agronomy, v. 10, p.435-473, 1958. 
EMBRAPA - EMPRESA BRASILEIRA DE PESQUISA AGROPECUÁRIA. Serviço Nacional de Levantamento e Conservação de Solos. Manual de métodos de análise e conservação de solos. Rio de Janeiro, 1979. v.1.

ESECHIE, H.A. Effect of planting density on growth and yeld of irrigated maize (Zea mays) in the Batinah Coast region of Oman. Journal of Agricultural Science, v.119, p.165-169, 1992.

FNP CONSULTORIA \& COMÉRCIO. AGRIANUAL. São Paulo, 1997. p. 301-317: A conquista do milho transgênico.

GADANHA, C.D.J.; MOLIN, P.M.; COLHO, J.L.D. et al. Máquinas e implementos agrícolas do Brasil. Campinas: Emopi. 1991. 468 p.

GASSEN, D.N. Perspectiva para a pequena propriedade sob semeadura direta. In: CONFERÊNCIA ANUAL DE SEMEADURA DIRETA, 2., Pato Branco, 1997. Anais. Passo Fundo: Aldeia Norte, 1997. p. 83-101.

GOMES, F.P. Curso de estatística experimental. Piracicaba: EDUSP, 1978. 433p.

GRECO, C.; MENEZES, J.F.; ARRUDA, P.E. de et al. Ensaio de semeadeira adubadeira. Jundiai: Divisão de Mecanização Agrícola, 1968. 25 p.

INTERNATIONAL STANDARDIZATION ORGANIZATION. 1984. ISO 7256-1: 1984. Sowing equipment - Test methods - Part 1: Single seed drills (precision drils), 7256/1.

KACHMAN, S.D.; SMITH J.A. Altemative measures of accurracy in plant spacing for planters using single seed metering. Transactions of the ASAE, v.38, n.38, p.379387, 1995.

KEPNER R. A.; BAINER. E.L. Crop planting. In:. Principles of farm machinery. 3.ed. Westport: The Avi Publishing Company INC, 1972. cap.10, p.201-247. 
KURACHI, S.A.H.; COSTA, J.A.S.; BERNARDI, J.A. et al Avaliação tecnológica de semeadoras e/ou adubadoras: tratamento de dados de ensaio e regularidade de distribuição longitudinal de sementes. Bragantia, v. 48, n.2, p.249-262, 1989.

KURACHI, S.A.H.; COSTA, J.A.S.; BERNARDI, J.A. et al. Avaliação tecnológica: resultados de ensaios de mecanismos dosadores de semeadoras -adubadoras de precisão. Campinas: IAC, 1993. 46p. (IAC. Boletim Científico, 28).

LAFLEN, J.M.; AMEMIYA, M.; HINTZ, E.A. Measuring crop residue cover. Journal of soil and water conservation, v.36, n.6, p.341-343, Nov./Dec. 1981.

LEITE, D. Comportamento do milho em diferentes densidades de plantio. Piracicaba, 1973. 90p. Dissertação (Mestrado) - Escola Superior de Agricultura Luiz de Queiroz, Universidade de São Paulo.

MANTOVANI, E.C.; BERTAUX, S.; ROCHA, F.E. de C. Avaliação da eficiência operacional de diferentes semeadoras-adubadoras de milho. Pesquisa Agropecuária Brasileira, v.27, n.12, p.1579-1586, dez.1992.

MARCOS FILHO, C.; CICERO, S.M.; SILVA, W.R. Avaliação da qualidade das sementes. Piracicaba: FEALQ, 1985. 230 p.

MELO, F.H. Um balanço da crise agrícola do ano de 1995. CARTA HM, p. 8-14. Mar. 1996.

MELLO, J.da S. Sistema de produção animal integrados com sistemas agrícolas em semeadura direta. In: CONFERÊNCIA ANUAL DE SEMEADURA DIRETA, 2., Pato Branco, 1997. Anais. Passo Fundo: Aldeia Norte, 1997. p.7-16.

MOLIN, J.P.; CHANG, C.S. Desenvolvimento e testes de dosador vertical para semeadoras de precisão. In: CONGRESSO BRASILEIRO DE ENGENHARIA AGRÍCOLA, 20., Londrina, 1991. Anais. Londrina: SBEA, 1991. p. 1667-1679. 
MOLIN, J.P.; D'AGOSTINI, V. Develompment of a rolling punch planter for stony Soil conditions. Agricultural Mechanization in Asia, Africa and Latin America, v.27, n.2, p.17-19, 1996.

MOLIN, J.P,; BASHFORD, L.L.; BARGEN, K. V. et al. Design and evaluation of a punch planter for no-till systems. St. Joseph: ASAE, 1996. 17p. (ASAE. Paper, 961046).

MONTEIRO, J. A. O grau de concentração da produção de milho no Centro-Sul Brasileiro. Pesquisa Agropecuária Brasileira. Brasília; Julho de 1994. v.29, p.1007-1017.

MONTEIRO, L.R. Desenvolvimento e análise de uma semeadora pneumática de grãos. Campinas, 1989. 122p. Dissertação (Mestrado) - Faculdade de Engenharia Agrícola, Universidade Estadual de Campinas.

MOREIRA, C.; PEREIRA, J. C. V. N. A.; MENEZES, J. F. de S. Desempenho de mecanismos dosadores-distribuidores de sementes em plantadeirasadubadeiras. Campinas: IAC, 1978. 21p. (IAC. Circular, 90).

NIELSEN, R.L. Planting speed effects on stand establishment and grain yeld of com. Journal of Production Agriculture. v.8, n.3, p.391-393, 1995 .

OGLIARI, A. Estudo e desenvolvimento de mecanismos dosadores de precisão de máquinas semeadoras. Florianópolis, 1990. 165p. Dissertação (Mestrado) Faculdade de Engenharia Mecânica, Universidade Federal de Santa Catarina.

PACHECO, E.P. Avaliação de uma semeadoa-adubadora de precisão com modificações no tubo condutor de sementes. Viçosa, 1994. 61p. Dissertação (Mestrado) - Universidade Federal de Viçosa. 
PASQUA, S.E.; MILAN, M.; PECHE, A. F. Controle de qualidade em operações agrícolas mecanizadas. In: CONGRESSO BRASILEIRO DE ENGENHARIA AGRÍCOLA, 25; CONGRESSO LATINO AMERICANO DE INGENERIA AGRÍCOLA, 2., Bauru, 1996. Anais, Bauru: SBEA/ALIA, 1996. /Resumo em CAB Abstract on CD-ROM, 1996.

PORTELLA, J.A.; SATTLER A.; FAGANELLO, A. A semeadura direta no campo nativo, os sistemas de rompimento do solo. In: SEMINÁRIO SOBRE SEMBRA DIRETA-EXPOATIVA-96, 1., Mercedes: 1996.

POZAR, G. ZAGO, C.P.; Influência da densidade em milho (Zea mays, L.) sobre a produção de grãos e silagem, e alguns de seus componentes de produção e de qualidade. Capinópolis: Sementes Agroceres, 1990. 29 p.

RAZERA, L. F. Efeito de danificações mecânicas causadas por semeadoras em sementes de soja. Piracicaba, 1979. 67p. Dissertação (Mestrado) - Escola Superior de Agricultura Luiz de Queiroz, Universidade de São Paulo.

RIZARDI, M. A.; BOLLER, W.; DALLOGLIO, R. Distribuição de plantas de milho, na linha de semeadura e seus efeitos nos componentes de produção. Pesquisa Agropecuária Brasileira, v. 29, n. 8, p.1231-1236, 1994.

RUSSEL, W.A. Effect of angle on hybrid performance in maize (Zea mays L). Crop Science, v. 12, p.90-92, Jan/Feb. 1972.

SAS INSTITUTE INC. SAS User guide statistic. Cary. 1994, v.6. 956 p.

TESTA, V.M.; NADAL, R.; MIOR, L. C. et al. O desenvolvimento sustentável do Oeste de Santa Catarina: proposta para discussão. Florianópolis: EPAGRI, 1996. $247 \mathrm{p}$.

TOURINO, M. C.; DANIEL, A. L. Avaliação da uniformidade de distribuição de sementes de soja (Glycyne max (L) Merril). Ciência e Agrotecnologia, v.20, n.2, p. 238-244, abr./jun. 1996. 
TOURINO, M.C.; KLINGNSTEINER, P. Ensaio e avaliação de semeadorasadubadoras. In: CONGRESSO BRASILEIRO DE ENGENHARIA AGRÍCOLA, 8., Rio de Janeiro, 1983. Anais. Rio de Janeiro: UFRRJ, 1983. v.2, p.103-116.

WILLIAMS, W.A.; LOOMIS, R.S.; DUNCAN, W.G. et al. Canopy architecture at various population densities and the growth and yield of com. Crop Science, v.8, p.303-308, May/June 1968. 


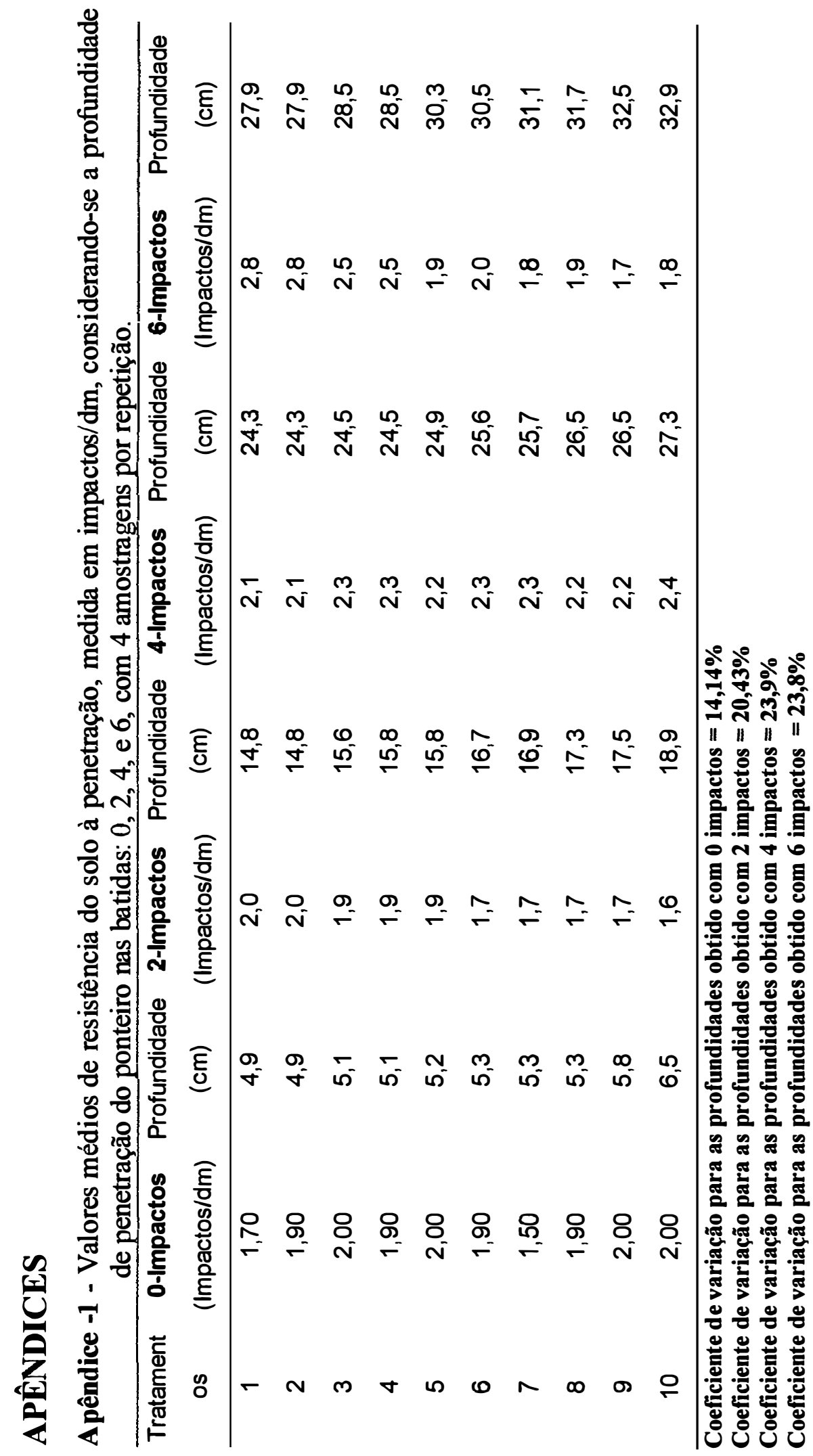




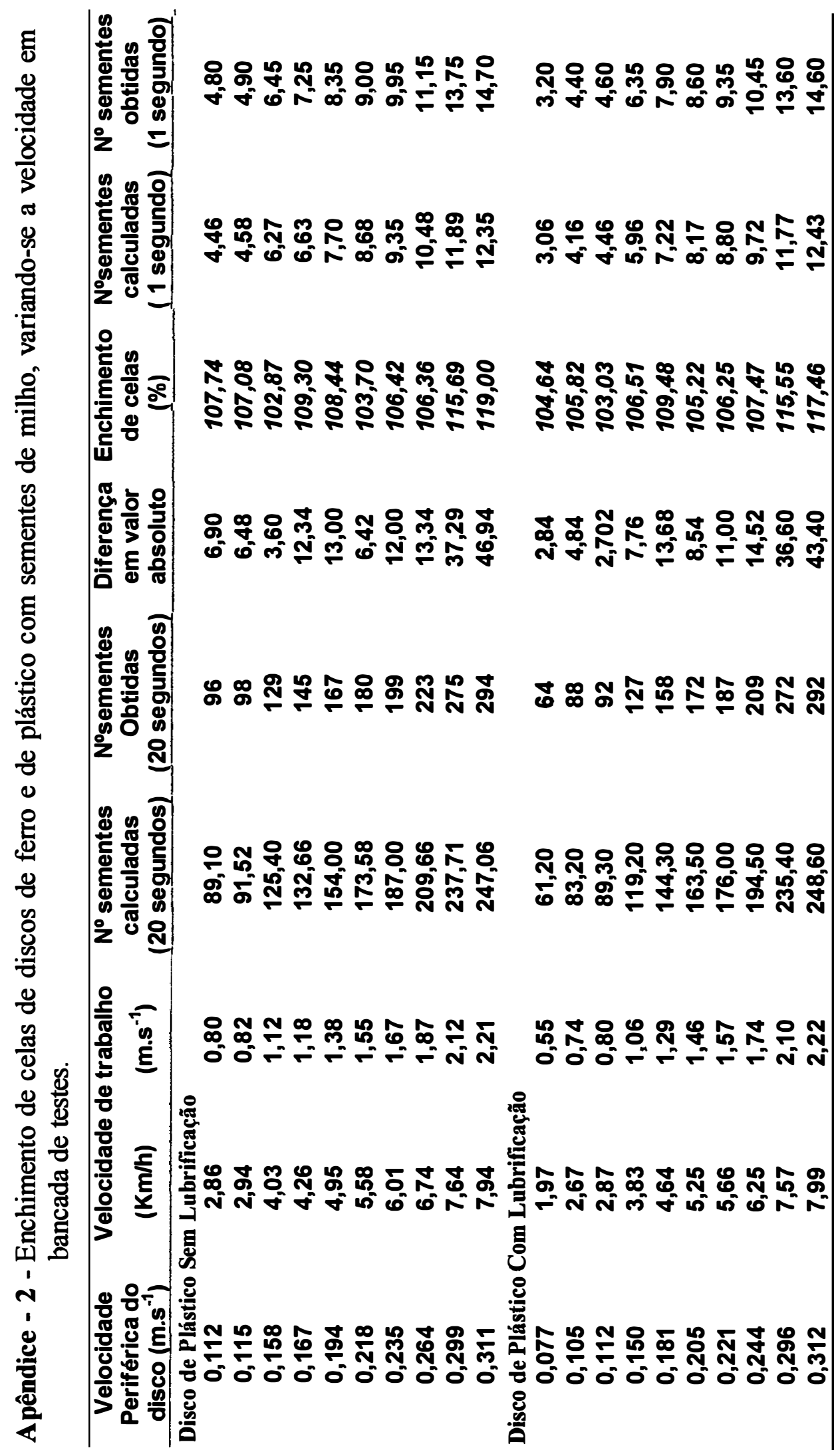




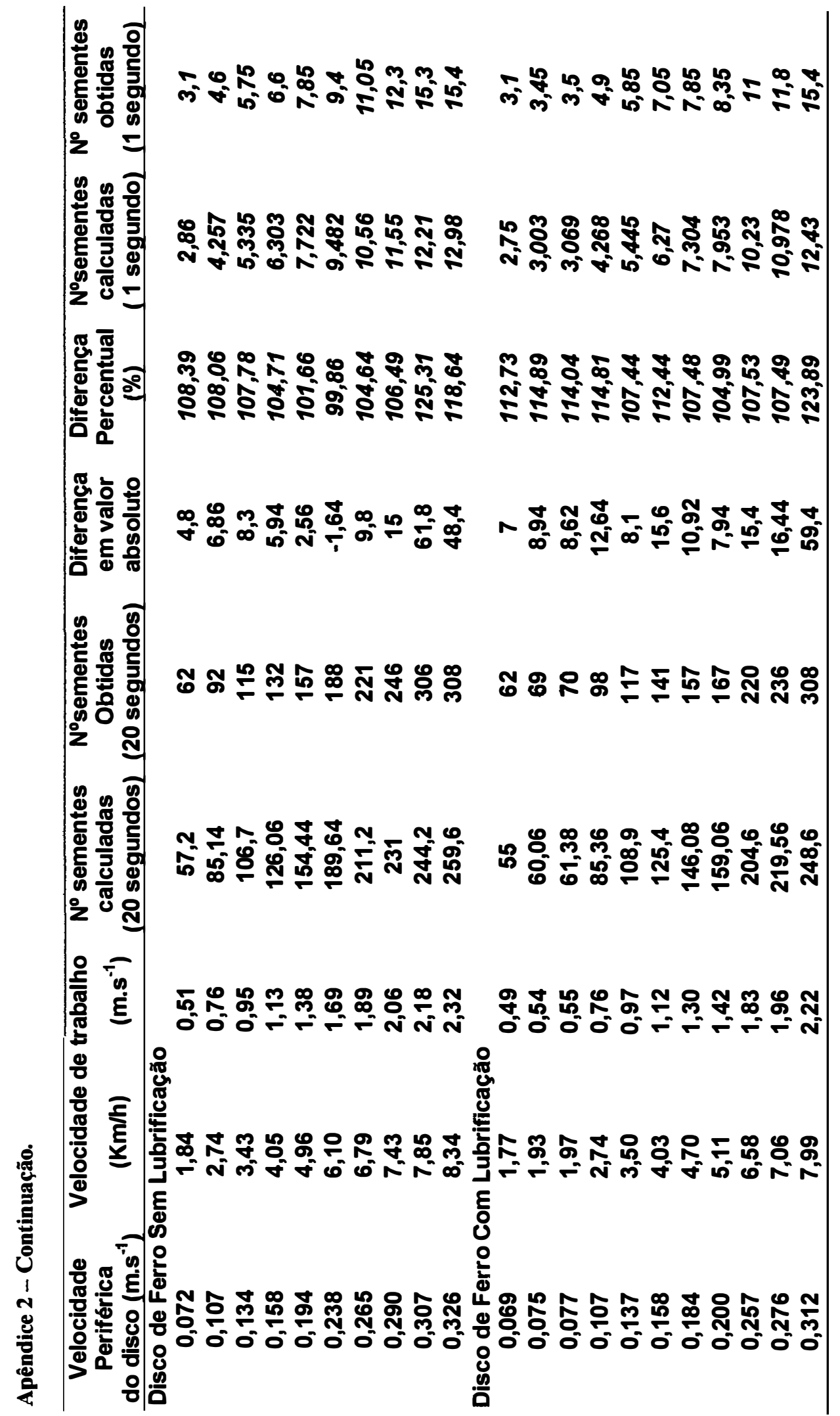


Apêndice 3 - Dados referentes a germinação, vigor e danos físicos às sementes utilizadas.

\begin{tabular}{|c|c|c|c|}
\hline Tratamento & Germinaçào (\%) & Vigor (\%) & Danos (\%) \\
\hline 1 & 94 & 80 & 9 \\
\hline 1 & 94 & 78 & 8 \\
\hline 1 & 93 & 75 & 5 \\
\hline 1 & 94 & 79 & 7 \\
\hline 2 & 93 & 83 & 11 \\
\hline 2 & 95 & 74 & 9 \\
\hline 2 & 89 & 67 & 5 \\
\hline 2 & 92 & 79 & 7 \\
\hline 3 & 97 & 89 & 7 \\
\hline 3 & 92 & 74 & 8 \\
\hline 3 & 94 & 80 & 7 \\
\hline 3 & 97 & 72 & 4 \\
\hline 4 & 97 & 73 & 3 \\
\hline 4 & 93 & 81 & 4 \\
\hline 4 & 96 & 77 & 6 \\
\hline 4 & 94 & 86 & 3 \\
\hline 5 & 93 & 80 & 2 \\
\hline 5 & 94 & 82 & 8 \\
\hline 5 & 93 & 83 & 6 \\
\hline 5 & 94 & 81 & 5 \\
\hline 6 & 96 & 83 & 4 \\
\hline 6 & 94 & 76 & 7 \\
\hline 6 & 94 & 80 & 7 \\
\hline 6 & 91 & 80 & 3 \\
\hline 7 & 95 & 83 & 4 \\
\hline 7 & 97 & 85 & 4 \\
\hline 7 & 96 & 79 & 4 \\
\hline 7 & 95 & 82 & 5 \\
\hline 8 & 93 & 76 & 3 \\
\hline 8 & 94 & 83 & 6 \\
\hline 8 & 93 & 87 & 5 \\
\hline 8 & 93 & 82 & 4 \\
\hline 9 & 94 & 79 & 5 \\
\hline 9 & 94 & 86 & 4 \\
\hline 9 & 94 & 80 & 5 \\
\hline 9 & 97 & 83 & 3 \\
\hline 10 & 96 & 78 & 3 \\
\hline 10 & 95 & 79 & 4 \\
\hline 10 & 92 & 84 & 5 \\
\hline 10 & 98 & 83 & 4 \\
\hline Testemunha & 94 & 82 & 7 \\
\hline « & 98 & 79 & 3 \\
\hline “ & 94 & 85 & 6 \\
\hline “ & 94 & 81 & 3 \\
\hline
\end{tabular}

Laboratório de Sementes da ESALQ -USP 
Apêndice 4 - Número de espaços medidos, plantas contadas em 24 m de cada tratamento, e população calculada de plantas por hectare.

\begin{tabular}{|c|c|c|c|c|}
\hline Tratamento & Repetição & $\begin{array}{c}N^{\circ} \text { de Espaços } \\
\text { medidos }\end{array}$ & $\begin{array}{l}\text { No de plantas } \\
\text { contadas }\end{array}$ & $\begin{array}{c}\text { População } \\
\text { (Plantas.ha }^{-1} \text { ) }\end{array}$ \\
\hline 1 & 1 & 107 & 108 & 50000 \\
\hline 1 & 2 & 100 & 101 & 46759 \\
\hline 1 & 3 & 114 & 115 & 53240 \\
\hline 1 & 4 & 100 & 101 & 46759 \\
\hline 2 & 1 & 109 & 110 & 50925 \\
\hline 2 & 2 & 100 & 101 & 46759 \\
\hline 2 & 3 & 101 & 102 & 47222 \\
\hline 2 & 4 & 102 & 103 & 47685 \\
\hline 3 & 1 & 101 & 102 & 47222 \\
\hline 3 & 2 & 118 & 119 & 55092 \\
\hline 3 & 3 & 98 & 99 & 45833 \\
\hline 3 & 4 & 98 & 99 & 45833 \\
\hline 4 & 1 & 94 & 95 & 43981 \\
\hline 4 & 2 & 113 & 114 & 52777 \\
\hline 4 & 3 & 108 & 109 & 50462 \\
\hline 4 & 4 & 105 & 106 & 49074 \\
\hline 5 & 1 & 101 & 102 & 47222 \\
\hline 5 & 2 & 112 & 113 & 52314 \\
\hline 5 & 3 & 111 & 112 & 51851 \\
\hline 5 & 4 & 115 & 116 & 53703 \\
\hline 6 & 1 & 106 & 107 & 49537 \\
\hline 6 & 2 & 119 & 120 & 55555 \\
\hline 6 & 3 & 106 & 107 & 49537 \\
\hline 6 & 4 & 101 & 102 & 47222 \\
\hline 7 & 1 & 108 & 109 & 50462 \\
\hline 7 & 2 & 122 & 123 & 56944 \\
\hline 7 & 3 & 109 & 110 & 50925 \\
\hline 7 & 4 & 110 & 111 & 51388 \\
\hline 8 & 1 & 95 & 96 & 44444 \\
\hline 8 & 2 & 111 & 112 & 51851 \\
\hline 8 & 3 & 117 & 118 & 54629 \\
\hline 8 & 4 & 103 & 104 & 48148 \\
\hline 9 & 1 & 110 & 111 & 51388 \\
\hline 9 & 2 & 103 & 104 & 48148 \\
\hline 9 & 3 & 105 & 106 & 49074 \\
\hline 9 & 4 & 107 & 108 & 50000 \\
\hline 10 & 1 & 114 & 115 & 53240 \\
\hline 10 & 2 & 104 & 105 & 48611 \\
\hline 10 & 3 & 98 & 99 & 45833 \\
\hline 10 & 4 & 114 & 115 & 53240 \\
\hline
\end{tabular}


Apêndice 5 - Matéria seca e índice de cobertura nos tratamentos avaliados.

\begin{tabular}{|c|c|c|c|c|c|c|c|c|c|c|c|c|}
\hline \multirow[b]{2}{*}{ Atributos } & \multicolumn{10}{|c|}{ Repetiçōes } & \multirow{2}{*}{ Média } & \multirow{2}{*}{ CV\% } \\
\hline & $\mathbf{1}$ & 2 & 3 & 4 & 5 & 6 & 7 & 8 & 9 & 10 & & \\
\hline $\begin{array}{c}\text { Matéria seca } \\
\left(\text { t.ha }^{-1}\right)\end{array}$ & 3,90 & 3,48 & 2,96 & 4,32 & 4,08 & 3,52 & 3,36 & 4,40 & 3,24 & 3,28 & 3,60 & 13,0 \\
\hline $\begin{array}{c}\text { Índice de } \\
\text { cobertura } \\
(\%)\end{array}$ & 82 & 96 & 92 & 78 & 83 & 78 & 87 & 93 & 78 & 83 & 85 & 7,9 \\
\hline
\end{tabular}

Apêndice 6 - Porcentagem de germinação das sementes de milho sem e com lubrificação.

\begin{tabular}{lcccccc}
\hline & \multicolumn{3}{c}{ Germinação } & & Média \\
\hline Sementes com lubrificação (\%) & 96 & 96 & 95 & 96 & 95.75 \\
\hline Sementes sem lubrificação (\%) & 97 & 96 & 95 & 97 & 96.25 \\
\hline
\end{tabular}


Apêndice 7 - Resultados da precisão (Coeficiente de variação calculado somente dos espaços aceitáveis compreendidos entre 12 a $33 \mathrm{~cm}$ ).

\begin{tabular}{cccccc}
\hline Tratamentos & Repetição & C (\%) & Tratamentos & Repetição & C (\%) \\
\hline 1 & 1 & 27,02 & 6 & 1 & 30,60 \\
1 & 2 & 28,25 & 6 & 2 & 28,10 \\
1 & 3 & 27,10 & 6 & 3 & 26,40 \\
1 & 4 & 27,52 & 6 & 4 & 28,90 \\
2 & 1 & 29,70 & 7 & 1 & 25,28 \\
2 & 2 & 27,78 & 7 & 2 & 26,40 \\
2 & 3 & 25,80 & 7 & 3 & 24,70 \\
2 & 4 & 27,20 & 7 & 4 & 26,20 \\
3 & 1 & 24,60 & 8 & 1 & 28,20 \\
3 & 2 & 26,90 & 8 & 2 & 29,30 \\
3 & 3 & 25,90 & 8 & 3 & 26,40 \\
3 & 4 & 25,30 & 8 & 4 & 28,60 \\
4 & 1 & 30,00 & 9 & 1 & 20,80 \\
4 & 2 & 26,90 & 9 & 2 & 25,40 \\
4 & 3 & 32,00 & 9 & 3 & 25,40 \\
4 & 4 & 27,10 & 9 & 4 & 26,00 \\
5 & 1 & 27,20 & 10 & 1 & 26,20 \\
5 & 2 & 33,20 & 10 & 2 & 29,30 \\
5 & 3 & 26,60 & 10 & 3 & 29,40 \\
5 & 4 & 27,70 & 10 & 4 & 24,00 \\
\hline & & & & &
\end{tabular}

